\title{
How Effective are Macroprudential Policies in China?
}

\author{
Bin Wang and Tao Sun
}




\title{
IMF Working Paper
}

Monetary and Capital Markets Department

\section{How Effective Are Macroprudential Policies in China?}

\author{
Prepared by Bin Wang and Tao Sun \\ Authorized for distribution by Karl Habermeier
}

March 2013

\section{This Working Paper should not be reported as representing the views of the IMF.}

The views expressed in this Working Paper are those of the author(s) and do not necessarily represent those of the IMF or IMF policy. Working Papers describe research in progress by the author(s) and are published to elicit comments and to further debate.

\begin{abstract}
This paper investigates macroprudential policies and their role in containing systemic risk in China. It shows that China faces systemic risk in both the time (procyclicality) and crosssectional (contagion) dimensions. The former is reflected as credit and asset price risks, while the latter is reflected as the links between the banking sector and informal financing and local government financing platforms. Empirical analysis based on 171 banks shows that some macroprudential policy tools (e.g., the reserve requirement ratio and house-related policies) are useful, but they cannot guarantee protection against systemic risk in the current economic and financial environment. Nevertheless, better-targeted macroprudential policies have greater potential to contain systemic risk pertaining to the different sizes of the banks and their location in regions with different levels of economic development. Complementing macroprudential policies with further reforms, including further commercialization of large banks, would help improve the effectiveness of those policies in containing systemic risk in China.
\end{abstract}

JEL Classification Numbers: E43, E58, G18, G28

Keywords: Systemic risk, Macroprudential policies, Effectiveness, Author's E-Mail Address: wangbin@bj.pbc.gov.cn and tsun@imf.org 


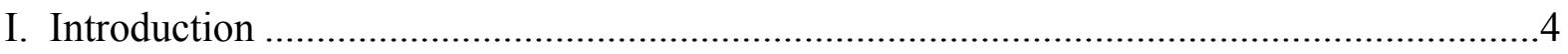

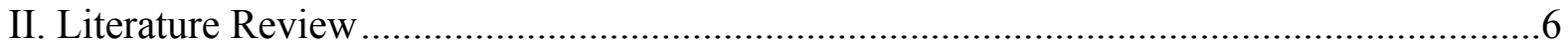

A. Identifying Systemic Risk …………………………....................................6

B. Selecting Macroprudntial Policy Tools ...............................................................

C. Determining the Institutional Arrangement …………………….............................11

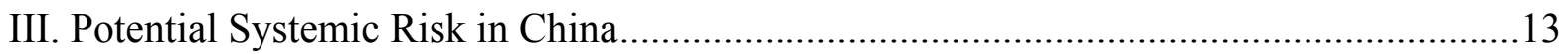

A. China-Specific Circumstances ……………………............................................

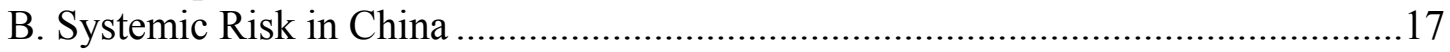

IV. Stylized Facts on Macroprudential Policies and Their Effectiveness ..............................22

A. China's Macroprudential Policy Toolkit................................................................22

B. China's Macroprudential Institutional Arrangement ……………………..............25

C. Stylized Facts on the Effectiveness of China's Macroprudential Policies ..............26

V. Effectiveness of Macroprudential Policies_An Empirical Analysis....................................31

A. Data and Methodology ……………….............................................................. 31

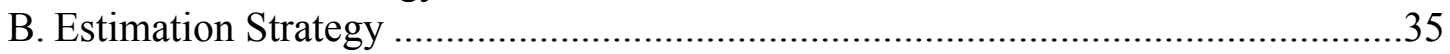

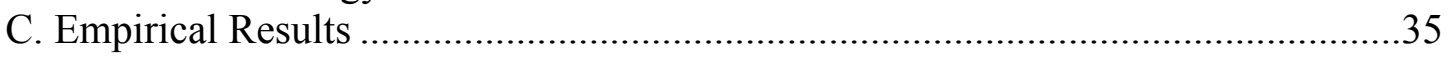

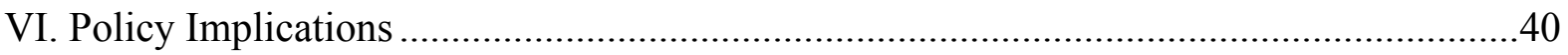

Tables

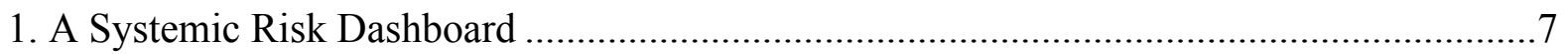

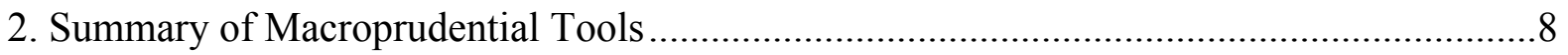

3. Alternative Sets of Tools to Foster Financial Stability ....................................................10

4. Summary of Institutional Arrangements for Macroprudential Policies...............................12

5. Indicators of Capital Account Openness in China, 2005-10 ………................................16

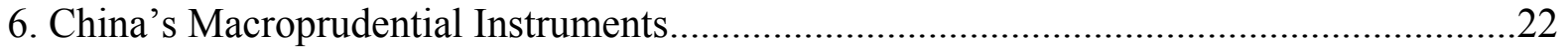

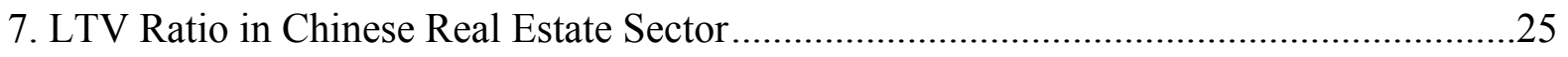

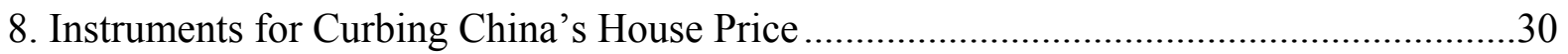

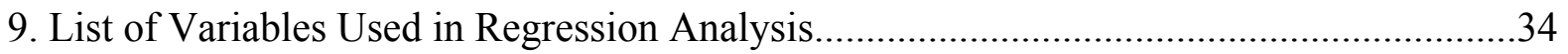

10. Summary of Fixed-Effects Panel Estimation Results ........................................................

11. Results of Individual Variables Based on Full Sample ..................................................51

12. Results of Individual Variables Based on the Sample of Large Bank ...............................52

13. Results of Individual Variables Based on the Sample of Small/Medium Banks...............53

14. Results of Individual Variables Based on the Sample of Banks in the East Region ..........54

15. Results of Individual Variables Based on the Sample of Banks in the Middle Region.....55

16. Results of Individual Variables Based on the Sample of Banks in the West Region.........56

17. Results of Multivariate Policies: Grouped by Size of Banks and Regions .........................57

18. Results of Multivariate Policies: Subgroups in Small- and Medium-Sized Banks ...........58

Figures

1. China has the Highest Investment-to-GDP Ratio in G-20 Countries .................................13 
2. Differences in GDP per Capita at Province Level ..............................................................14

3. Trends of Current Account, Hot Money and M2 in China, 2000-11 ................................15

4. Exchange Rate of RMB, M2 and Foreign Reserves, 2000-11 ........................................15

5. Size of Selected Countries' Financial Systems, end-2011 ..............................................16

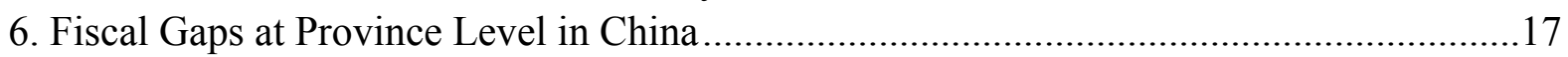

7. Credit Comparison: Five Years Before Housing Price Peaks ............................................18

8. Mortgages and House Price in China, 2008-10 ............................................................19

9. Comparing China's Housing Price Increases with Those in Other Housing Booms ..........19

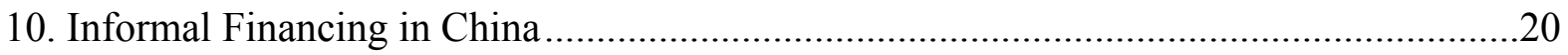

11. Loans by Local Government Financing Platforms Outweigh Local

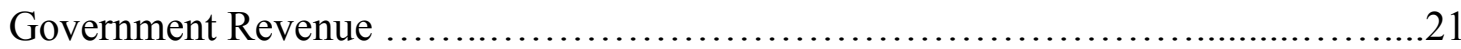

12. RRRs of China's Large Banks and Small/Medium Banks, 2008-12 .............................23

13. Loan Growth Rate Decreases and Increase in Lending Rate and RRR ,2010-12 .............26

14. China: Interest rate, RRR, and Quarterly Growth in Domestic Credit, 2000-11 .............27

15. Mortgage and House Price in China, 2010-11 …......................................................28

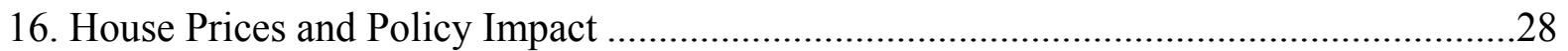

17. Understanding the Rationale of Macroprudential Policies in China ..................................30

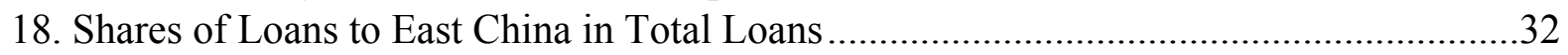

19. Different House Price Impact of the RRR on Different Types of Banks ...........................38

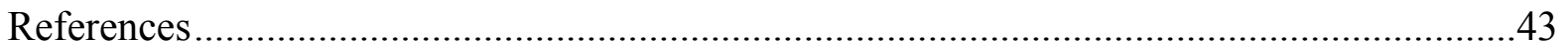

Annexes

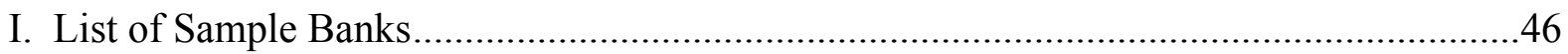

II. Detailed Panel Estimation Results ............................................................................. 


\section{INTRODUCTION ${ }^{1}$}

The unprecedented scope and intensity of the recent global financial crisis underscores the urgency of promoting financial stability. The endeavor to enhance financial stability can be roughly categorized into three broad streams: (i) surveillance - the early identification of potential threats to financial stability; (ii) mitigation - the measures to make the financial system more resilient to shocks; and (iii) crisis management - the principles and procedures for responding to distress or failures in the financial system.

Establishing and implementing a macroprudential policy framework forms the core of the first and second streams for enhancing financial stability - surveillance and mitigation. In particular, the mitigation of systemic risk has made the establishment of a macroprudential policy framework a global objective.

The successful design and implementation of macroprudential policies in China is vital. Given China's sheer economic size, the effectiveness of its policies is of significance for both China's and the world's financial stability. Furthermore, as a large emerging economy, China's experiences gained through this process may be useful to other economies.

\section{This paper investigates the following three questions:}

- What is the potential systemic risk in China's current macroeconomic and financial environment?

- What macroprudential policies have the Chinese authorities introduced in recent years?

- How effective have these macroprudential policies been in addressing the potential systemic risk?

This paper shows that systemic risk exists in China both in the time dimension and the cross-sectional dimension. The former takes the form of excessive growth in credit and asset prices, and the latter is mainly reflected as the links between the banking sector and informal financing and local government financing platforms. To address the potential systemic risk, the Chinese authorities have initiated a set of macroprudential policies, including dynamic adjustment of the differentiated reserve requirement, capital and liquidity buffers, and house-related policies.

\footnotetext{
${ }^{1}$ Bin Wang works in the People's Bank of China and was a special appointee at the International Monetary Fund. Tao Sun is a senior economist at the International Monetary Fund. The authors would like to thank Karl Habermeier, Erlend Nier, Jacek Osiński, Yuepeng Zhao, Zuhong Wu, Yi Huang, Yanliang Miao, and other colleagues at the IMF for valuable comments. Thanks are also due to Jessica Allison for her technical support. Remaining errors and omissions are our own responsibility.
} 


\section{This paper finds that some macroprudential policy tools are effective in containing} systemic risk associated with China's current economic and financial environment. However, it is important to identify the possible differences in the role of macroprudential policies in relation to banks' location and size. Thus, this paper analyzes data on 171 banks to explore the respective roles of monetary and macroprudential policies in different regions and for various sizes of banks. It concludes with the following policy implications:

- $\quad$ The current economic and financial environment, particularly the policy response to the global financial crisis, requires macroprudential policies to address systemic risk. Some macroprudential policy tools such as the required reserve ratio (RRR) and house-related policies can help contain increases in house prices.

- $\quad$ Better-targeted macroprudential policies have greater potential to contain risk pertaining to the different size and locations of the banks. For instance, policy could be differentiated between the banks in the east, middle and west China, between large banks and small and medium-sized banks, with less tough macroprudential policies being applied to banks in the west and to small and medium-sized banks.

- It is hard to expect macroprudential policies to be able to contain all the systemic risk associated with the current economic and financial environment. Some systemic risk can only be addressed by further financial, fiscal, and structural reforms. For instance, the further commercialization of large banks and financial liberalization can help improve the effectiveness of macroprudential policies.

- With further liberalization going forward, it would be important to further adjust the macroprudential policy toolkit in China. With coordination and synergies, monetary and macroprudential policies can help achieve both price stability and financial stability, thus greatly enhancing the welfare of the Chinese people.

This paper differs from other studies in three respects. First, this paper explores systemic risk by considering economic, financial, and transitional features in China. Second, it uses individual bank data, instead of aggregate data, to investigate the effectiveness of macroprudential policies. Third, the paper takes advantage of a tailored approach to study the usefulness and constraints of policies, by reviewing systemic risk in a macro-financial framework.

The paper proceeds as follows. Section II briefly reviews the literature on systemic risk and macroprudential policies in the context of identification of systemic risk, policy tools, and institutional arrangements. Section III discusses the potential systemic risk arising from the current macroeconomic and financial environment in China. Section IV presents the stylized facts on the macroprudential policies adopted by the Chinese authorities, and the evidence of their effects. Section V investigates the role of macroprudential policies in addressing systemic risk by using a sample of 171 banks while incorporating the role of monetary policy. Section VI concludes with policy implications. 


\section{LITERATURE REVIEW}

Macroprudential policies address systemic risk in the financial system (Borio, 2009, Bank of England, 2011). There are three important issues: identifying systemic risk, selecting macroprudential tools, and determining the appropriate institutional arrangement.

\section{A. Identifying Systemic Risk}

Systemic risk is the risk of disruptions in the provision of key financial services that can have serious consequences for the real economy (IMF, 2009). Systemic events are intrinsically difficult to anticipate, though once they have occurred it is easier to look back and agree that a disruption was, in fact, systemic (IMF, April 2010). There are two types of systemic risk. One is the risk in the time dimension. The other is the risk in the crosssectional or interconnectedness dimension.

The time dimension risk relates to the way in which aggregate risk evolves over time. In particular, there is a procyclical bias, with financial institutions tending to take on excessive amounts of risk in the upswing of an economic cycle, only to become overly risk-averse in a downswing. In other words, this type of systemic risk is most often shown in procyclicality of credit and asset/collateral booms and busts. This characteristic amplifies the boom and bust cycle through the supply of credit and liquidity — and, by extension, in asset priceswhich is so damaging to the real economy.

The cross-sectional dimension risk is interconnectedness or network risk owing to common exposures and interconnectedness that exist within the financial system. Thus, this dimension considers the relationships that work to amplify and rapidly transmit shocks between financial institutions. As a result, the failure of one institution, particularly one of significant size or market share, can threaten the system as a whole. Counterparty credit risk and interbank freezes are the typical forms of this type of systemic risk.

\section{Macroprudential policies address the time (procyclicality) and cross-sectional} (contagion) dimensions of risks in a financial system. It is crucial to clearly identify systemic risk in order to determine macroprudential policies. Although this is a hard task because of the lack of data and research, the G20 report (FSB-IMF-BIS, 2011) provides a basic guide. This document suggests using (i) aggregate indicators of imbalances like bank credit and external imbalances to signal the build-up of time dimension risk in the whole economy; and (ii) high frequency indicators of market conditions, macro stress testing, and metrics of concentration of risk within the system to identify the cross-sectional risk. Countries need to select appropriate indicators according to their specific circumstances and the feature of each indicator. IMF (2011) provides a deeper insight on this issue by suggesting (i) an improvement in the early warning capability based on indicators of the credit-to-GDP gap, the bank stability index, and the systemic contingent claims analysis 
(CCA); (ii) construction of integrated systemic risk measures through combining signals from individual tools; and (iii) a systemic risk dashboard (Table 1).

Table 1. A Systemic Risk Dashboard

\begin{tabular}{|l|l|l|l|}
\hline \multicolumn{1}{|c|}{ Systemic Risk } & \multicolumn{1}{|c|}{ Channels } & \multicolumn{1}{|c|}{$\begin{array}{c}\text { Low Frequency Monitoring } \\
\text { Tools }\end{array}$} & \multicolumn{1}{c|}{$\begin{array}{c}\text { High Frequency Monitoring } \\
\text { Tools }\end{array}$} \\
\hline Aggregate measure & & Crisis risk models & Systemic CCA \\
\hline Likelihood of shocks & $\begin{array}{l}\text { From asset quality/price } \\
\text { deviation }\end{array}$ & $\begin{array}{l}\text { Credit/GDP deviation, House } \\
\text { prices }\end{array}$ & $\begin{array}{l}\text { Regime shifts in financial } \\
\text { market } \\
\text { volatility (e.g., interest rate, } \\
\text { currency, } \\
\text { and equity markets) }\end{array}$ \\
\cline { 2 - 4 } & $\begin{array}{l}\text { From } \\
\text { concentrations/connecte } \\
\text { dness }\end{array}$ & $\begin{array}{l}\text { Interbank exposures, } \\
\text { Core/non-core liabilities } \\
\text { (aggregate) }\end{array}$ & $\begin{array}{l}\text { Distress dependence (JPod, } \\
\text { BSI) }\end{array}$ \\
\hline Potential impact & $\begin{array}{l}\text { Through balance sheet } \\
\text { exposures }\end{array}$ & $\begin{array}{l}\text { Leverage measure, Macro } \\
\text { stress tests }\end{array}$ & $\begin{array}{l}\text { EDF measures for main SIFls } \\
\text { Through } \\
\text { interconnectedness }\end{array}$ \\
\cline { 2 - 4 } & $\begin{array}{l}\text { border exposures of banking } \\
\text { systems }\end{array}$ & $\begin{array}{l}\text { CCA-related measures of joint } \\
\text { losses }\end{array}$ \\
\hline
\end{tabular}

Source: Box 4 in IMF (2011)

Note: CCA stands for Contingent Claims Analysis; JPod=Joint Probability of Distress; BSI=Banking Stability Indicator; EDF=Expected Default Frequency.

\section{B. Selecting Macroprudential Policy Tools}

Although no consensus has been reached about a macroprudential policy toolkit, IMF
(2011) listed some commonly used macroprudential tools for addressing the time and
cross-sectional dimensions of risk (Table 2). For example, countercyclical capital buffers and time-varying loan-to-value (LTV) ratios relate to time dimension risk; systemic capital surcharges and levies on non-core liabilities relate to the cross-sectional dimension risk. The G20 agreed to deal with the time dimension of systemic risk through tools ${ }^{2}$ advanced by Basel III in 2010, which include a permanent capital conservation buffer (2.5 percent of Common Equity Tier 1 Capital) $)^{3}$, a countercyclical capital buffer that ranges from 0 to 2.5 percent of risk-weighted assets $^{4}$, a minimum leverage ratio, and new liquidity standards. The Financial Stability Board (FSB) framework, which focuses on the cross-

\footnotetext{
${ }^{2}$ IMF (2011) argued that it is difficult to distinguish between "micro" and "macro" instruments in practice.

${ }^{3}$ A permanent capital conservation buffer enables banks to cover losses without hitting the minimum capital adequacy ratio (CAR).
}

${ }^{4}$ A countercyclical capital buffer is used to reduce pro-cyclicality risk. Benchmarked against the credit-to-GDP indicator, the buffer is accumulated during the period with excess credit growth to absorb losses in the period of the economic slowdown. The buffer is therefore a stabilizer during the boom and bust cycle. 
sectional risks posed by systemically important financial institutions (SIFIs), suggests some tools such as additional loss-absorbency capability and resolution requirements for SIFIs.

Table 2. Summary of Macroprudential Tools

\begin{tabular}{|c|c|c|}
\hline & Time Dimension & Cross-Sectional Dimension \\
\hline \multirow{5}{*}{$\begin{array}{l}\text { Instruments (instruments originally } \\
\text { developed for systemic risk) }\end{array}$} & Countercyclical capital buffers & Systemic capital surcharges \\
\hline & $\begin{array}{l}\text { Through-the-cycle valuation of } \\
\text { margins or haircuts for repos }\end{array}$ & Systemic liquidity surcharges \\
\hline & Levy on non-core liabilities & Levy on non-core liabilities \\
\hline & $\begin{array}{l}\text { Countercyclical change in risk } \\
\text { weights for exposure to certain } \\
\text { sectors }\end{array}$ & $\begin{array}{l}\text { Higher capital charges for trades not } \\
\text { cleared through CCPS }\end{array}$ \\
\hline & $\begin{array}{l}\text { Time-varying systemic liquidity } \\
\text { surcharges }\end{array}$ & \\
\hline \multirow{7}{*}{$\begin{array}{l}\text { Recalibrated instruments } \\
\text { (instruments not originally developed } \\
\text { for systemic risk, but becoming part } \\
\text { of the macroprudential toolkit after } \\
\text { being modified) }\end{array}$} & $\begin{array}{l}\text { Time-varying Loan-to-Value } \\
\text { (LTV), Debt-To-Income (DTI), } \\
\text { and Loan-To-Income (LTI) caps }\end{array}$ & $\begin{array}{l}\text { Powers to break up financial firms on } \\
\text { systemic risk concerns }\end{array}$ \\
\hline & $\begin{array}{l}\text { Time-varying limits on currency } \\
\text { mismatches or exposures (e.g. } \\
\text { real estate) }\end{array}$ & Capital charge on derivative payables \\
\hline & $\begin{array}{l}\text { Time-varying limits on loan-to- } \\
\text { deposit ratio }\end{array}$ & $\begin{array}{l}\text { Deposit insurance risk premiums } \\
\text { sensitive to systemic risk }\end{array}$ \\
\hline & $\begin{array}{l}\text { Time-varying caps and limits on } \\
\text { credit or credit growth }\end{array}$ & $\begin{array}{l}\text { Restrictions on permissible activities } \\
\text { (e.g. ban on proprietary trading for } \\
\text { systemically important banks) }\end{array}$ \\
\hline & Dynamic provisioning & \\
\hline & $\begin{array}{l}\text { Stressed VaR to build additional } \\
\text { capital buffer against market } \\
\text { risk during a boom }\end{array}$ & \\
\hline & \begin{tabular}{|l|} 
Rescaling risk-weights by \\
incorporating recessionary \\
conditions in the probability of \\
default assumptions (PDs)
\end{tabular} & \\
\hline
\end{tabular}

Source: IMF (2011)

A rich literature exists on how to apply the instruments. Apart from roughly grouping the instruments into the time and cross-sectional dimensions of systemic risk, Lim and others (2011) suggest a clearer guide by listing four broad categories of systemic risk. These comprise (i) risk generated by strong credit growth and credit-driven asset price inflation; (ii) risk arising from excessive leverage and the consequent deleveraging; (iii) systemic liquidity risk; and (iv) risk related to large and volatile capital flows including foreign currency lending. Moreover, Lim and others have identified ten frequently used instruments and grouped them into three types of instruments, namely credit related, ${ }^{5}$ liquidity-related, ${ }^{6}$

\footnotetext{
${ }^{5}$ Credit-related instruments include caps on the loan-to-value (LTV) ratio, caps on the debt-to-income (DTI) ratio, caps on foreign currency lending, and ceilings on credit or credit growth.
} 
and capital-related. ${ }^{7}$ These three types of instruments are therefore used to deal with the four broad categories of systemic risk. ${ }^{8}$

\section{Among the three types of instrument, an important macroprudential policy tool is the RRR, especially for emerging economies. The reasons are as follows:}

- $\quad$ The RRR is a system-wide measure of macroprudential policies rather than a sectorspecific tool like the LTV ratio;

- $\quad$ The RRR can deal effectively with systemic risk. For instance, reserve requirements and other macroprudential instruments have a moderate and transitory effect and play a complementary role to monetary policy (Camilo, Garcia-Escribano, and Marti, 2012); and the time-varying RRR rule countervails the negative effects of adverse macroeconomic shocks and the financial accelerator mechanism on real and financial variables (Mimir, Sunel, and Taskin, 2012).

- $\quad$ The RRR is proving to be a particularly useful macroprudential tool in emerging economies. Federico, A. Vegh, and Vuletin (2012) argue that the RRR has replaced monetary policy as a countercyclical tool, with 74 percent of emerging economies using the RRR as a countercyclical tool compared with just 38 percent in advanced economies that have engaged in countercyclical policy. Federico and others (2012) analyze the relationship between the reserve requirement policy as a macroprudential tool and monetary policy, based on 52 countries from 1970 to 2012. They conclude that the reserve requirement has replaced monetary policy as a countercyclical tool in most emerging economies owing to the reluctance of many emerging economies to reduce interest rates in bad times for fear of letting their currency depreciate rapidly or to raise interest rates in good times for fear of attracting even more capital inflows.

- $\quad$ The RRR provides a potential way to curb excessively strong credit growth. An increase in the RRR can reduce excessive credit growth without attracting new capital inflows and causing the exchange rate to appreciate. Moreover, when increases in RRR dampen capital inflows, this can give greater room for maneuver for monetary policies to increase the interest rate (Tovar and others, 2012).

\footnotetext{
${ }^{6}$ Liquidity-related instruments include limits on net open currency positions/currency mismatch (NOP), limits on maturity mismatch and reserve requirements.

${ }^{7}$ Capital-related instruments include countercyclical/time-varying capital requirements, time-varying/dynamic provisioning, and restrictions on profit distribution.

${ }^{8}$ FSB-IMF-BIS (2011) groups the various tools into (i) addressing risks from excessive credit expansion in the system; (ii) addressing key amplification mechanisms of system risk; and (iii) reducing structural vulnerabilities and limiting spillovers.
} 
- $\quad$ This said, the RRR has also been used as a monetary policy tool, and it is important to ensure that market participants understand clearly for what purposes the RRR is being used: to loosen or tighten monetary conditions, or to address systemic risk. Mixing the two functions of the RRR can confuse the signaling channel of monetary policy transmission.

Better coordination between macroprudential tools and other policy tools to address systemic risk has been also widely investigated. Gabriele Galati and Richhild Moessner (2011) provide alternative sets of tools to foster financial stability (Table 3). Among these various tools, macroprudential instruments are usually less blunt than monetary tools and have shorter implementation lags than fiscal tools. However, the effectiveness of macroprudential policy tools also hinges on their interplay with other policies.

Table 3. Alternative Sets of Tools to Foster Financial Stability

\begin{tabular}{|l|l|l|}
\hline \multicolumn{1}{|c|}{ Tool Set } & \multicolumn{1}{|c|}{ Goal } & \multicolumn{1}{|c|}{ Instruments } \\
\hline Micorprudential policy & $\begin{array}{l}\text { Limit distress of individual } \\
\text { institutions }\end{array}$ & Quality/quantity of capital, leverage ratio \\
\hline Macroprudential policy & $\begin{array}{l}\text { Limit financial system-wide } \\
\text { distress }\end{array}$ & Countercyclical capital charges \\
\hline Monetary policy & Price stability & Policy rate, standard repos \\
\cline { 2 - 3 } & Liquidity management & $\begin{array}{l}\text { Collateral policies; interest on reserves; } \\
\text { policy corridors }\end{array}$ \\
\cline { 2 - 3 } & $\begin{array}{l}\text { Lean against financial } \\
\text { imbalances }\end{array}$ & $\begin{array}{l}\text { Policy rate; reserve requirements; mop-up of } \\
\text { liquidity; foreign exchange reserve buffers }\end{array}$ \\
\hline Fiscal policy & Manage aggregate demand & $\begin{array}{l}\text { Taxes; automatic stabilizers; discretionary } \\
\text { countercyclical measures }\end{array}$ \\
\cline { 2 - 3 } & $\begin{array}{l}\text { Build fiscal buffers in good } \\
\text { times }\end{array}$ & $\begin{array}{l}\text { Measures to reduce debt levels; taxes/levies } \\
\text { on the financial system }\end{array}$ \\
\hline Capital controls & $\begin{array}{l}\text { Limit system-wide currency } \\
\text { mismatches }\end{array}$ & $\begin{array}{l}\text { Limits on open foreign exchange positions; } \\
\text { constraints on the type of foreign currency } \\
\text { assets }\end{array}$ \\
\hline Infrastructure policy & $\begin{array}{l}\text { Strengthen the resilience of } \\
\text { the infrastructure of the } \\
\text { financial system }\end{array}$ & Move derivative trading on exchanges \\
\hline
\end{tabular}

Source: FSB-IMF-BIS (2011) and Gabriele Galati and Richhild Moessner (2011).

Monetary and macroprudential policies are most effective when they complement each other. On the one hand, monetary policy can affect financial stability through the channels of balance sheets, risk taking, risk shifting, asset prices, and exchange rates. On the other hand, macroprudential policies have the potential to contain the undesirable effects of monetary policy and ease the burden on monetary policy. IMF suggests that monetary and macroprudential policies are mainly complements, not substitutes, although results vary by type of shock. Policymakers should employ monetary policy and macroprudential policies 
simultaneously, with the former focusing on price stability and the latter highlighting financial stability. Moreover, their interaction will depend on country-specific circumstances (i.e., financial structure and capital account openness) (IMF, 2012).

\section{Determining the Institutional Arrangement}

\section{The effectiveness of macroprudential policy requires an appropriate institutional}

arrangement. No single preferred arrangement is suitable for all countries owing to diversified circumstances across countries. Based on a survey, the IMF suggested four elements of existing institutional arrangements: (i) the institutional structure; (ii) the mandate; (iii) the independent powers of key policymakers; and (iv) accountability for financial stability. Based on this, Nier and others (2011a) summarize seven models of institutional arrangements based on five factors: (i) the roles of the central bank and other supervisory institutions in macroprudential policies; (ii) ownership of the macroprudential mandate; (iii) the role of government in macroprudential institutional arrangements; (iv) the degree to which there is organizational separation of decision making and control over instruments; and (v) whether a committee without a macroprudential mandate can coordinate several bodies. Based on three assessment criteria — effective identification of risks, timely and effective use of tools, and effective coordination across policy - they analyze the pros and cons of the seven models. They emphasize that the central bank should play a significant role in macroprudential policies, and the dominant participation of government (treasury) may give rise to significant risk (Table 4). 
Table 4. Summary of Institutional Arrangements for Macroprudential Policies

\begin{tabular}{|c|c|c|c|}
\hline Institutional Arrangements & Group of Full Integration & $\begin{array}{c}\text { Group of Partial Integration } \\
\text { (Twin peaks) }\end{array}$ & Group of Separation \\
\hline Key Feature & $\begin{array}{l}\text { Full integration within the } \\
\text { central bank of essentially all } \\
\text { financial regulatory and } \\
\text { supervisory functions. }\end{array}$ & $\begin{array}{l}\text { Integration between the } \\
\text { central bank and the } \\
\text { prudential supervisor and } \\
\text { regulator of potentially } \\
\text { systemic financial } \\
\text { institutions. }\end{array}$ & $\begin{array}{l}\text { Institutional separation between } \\
\text { the central bank and supervisory } \\
\text { functions }\end{array}$ \\
\hline Examples of Countries & Ireland, Czech Republic & $\begin{array}{l}\text { Netherlands, Belgium, the } \\
\text { U.K., and the U.S.A. } \\
\end{array}$ & Australia, Canada, and Chile \\
\hline Strengths & $\begin{array}{l}\text { 1) Easy delivery of relevant } \\
\text { prudential information to the } \\
\text { decision makers. } \\
\text { 2) Ensures that use is made of } \\
\text { existing expertise. } \\
\text { 3) Important experience in } \\
\text { communicating risks to the } \\
\text { markets and the general } \\
\text { public. } \\
\text { 4) Effective coordination } \\
\text { across objectives and } \\
\text { functions (macroprudential, } \\
\text { monetary, and } \\
\text { microprudential) takes place } \\
\text { within one organization. } \\
\text { 5) Clear mandate and } \\
\text { responsibility. }\end{array}$ & $\begin{array}{l}\text { 1) Limits reputational risks } \\
\text { of the central bank. } \\
\text { 2) Allows for treasury } \\
\text { participation, which can help } \\
\text { garner political support for } \\
\text { the actions of the committee. }\end{array}$ & $\begin{array}{l}\text { 1) Keeps each agency focused } \\
\text { on their main objective. } \\
\text { 2) Facilitates the management of } \\
\text { institutions, creates strong } \\
\text { institutional cultures in these } \\
\text { policy fields and ensures } \\
\text { separate accountability for } \\
\text { monetary and prudential policy. } \\
\text { 3) Little risk that any one } \\
\text { institution becomes dominant. }\end{array}$ \\
\hline Weaknesses & $\begin{array}{l}\text { 1) Lacks institutional } \\
\text { mechanisms to challenge the } \\
\text { "house views" formed within } \\
\text { the one institution. } \\
\text { 2) Concentrates a lot of } \\
\text { powers in the central banks. } \\
\text { 3) Perceived failures in } \\
\text { prudential policy can affect the } \\
\text { credibility of the monetary } \\
\text { policymaker. } \\
\text { 4) The treasury will typically be } \\
\text { excluded. }\end{array}$ & $\begin{array}{l}\text { 1) Inadequate engagement } \\
\text { and support of these } \\
\text { regulators outside of the } \\
\text { central bank. } \\
\text { 2) The policymaker has no } \\
\text { immediate control over } \\
\text { tools. } \\
\text { 3) Separation between } \\
\text { decision-making and control } \\
\text { over instruments remains an } \\
\text { issue. }\end{array}$ & $\begin{array}{l}\text { 1) No one institution has all the } \\
\text { information needed to analyze all } \\
\text { interlinked aspects of systemic } \\
\text { risk. } \\
\text { 2) Increases the risk of } \\
\text { "gaps"-risks remaining } \\
\text { undetected or unaddressed, or } \\
\text { uncoordinated "overlap." } \\
\text { 3) Dilutes accountability and } \\
\text { incentives. }\end{array}$ \\
\hline
\end{tabular}

Source: Authors' summary based on Nier (2011).

\section{Moreover, central banks play a more significant role in determining macroprudential policies in emerging market countries compared with advanced countries. A survey} initiated by the IMF (2011a) shows that those countries in which central banks are responsible for banking supervision account for two-thirds of the emerging market countries but only one-half of advanced countries. Given the significant capital inflows in most emerging market countries, Merrouche and Nier (2010) suggest that countries with stronger integration between the central bank and the banking supervisor are more likely to reduce increases in systemic risk associated with current account deficits. 


\section{Potential Systemic Risk In China}

Systemic risk has been rising in China owing to its existing macroeconomic and financial imbalances and, in particular, credit expansion over the past four years.

\section{A. China-Specific Circumstances}

Three China-specific circumstances are vital to understand the potential systemic risk in China.

First, economic imbalances, characterized by overreliance on investment and regional differences in economic development, are structural weaknesses that can contribute to systemic risk. Chinese economic growth has relied heavily on investment and net exports, with the average investment-to-GDP ratio amounting to 45 percent and the consumption-toGDP ratio being 40 percent between 2000 and 2011. China's investment-to-GDP ratio is the highest among G-20 economies (Figure 1). The current growth pattern may have also resulted in a general increase in credits and excess capacity. Another feature of the Chinese economy is the diverse stage of economic development across regions. For instance, the GDP per capita in Beijing is six times larger than that in Guizhou province (Figure 2). The regional differences sow the seeds of financial imbalances discussed below in this section.

Figure 1. China has the Highest Investment-to-GDP Ratio in G-20 Countries (In percent, 2011)

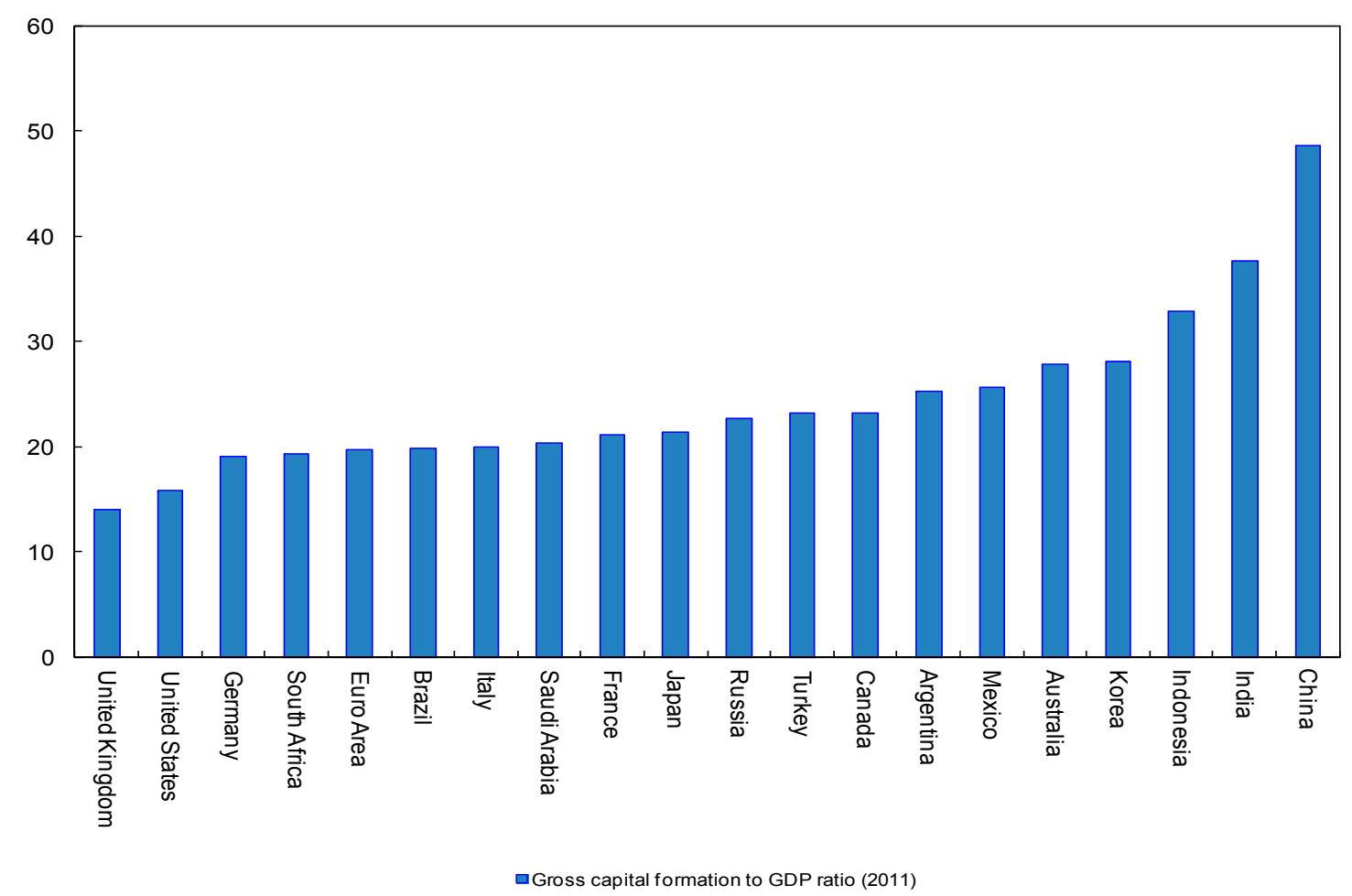

Source: International Financial Statistics and authors' estimates. 
Figure 2. Differences in GDP per Capita at Province Level

(RMB, 2006-11 annual average)

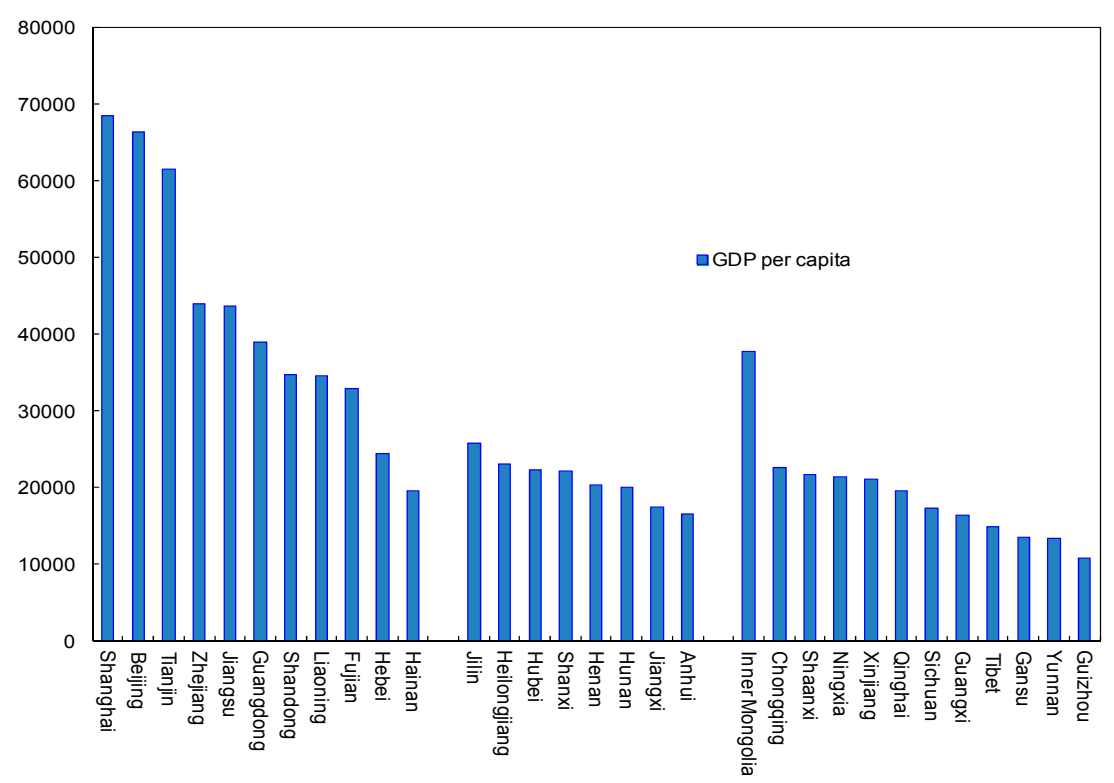

Source: CEIC.

\section{Second, unfinished reforms may create financial distortions that lead to systemic risk.} The exchange rate regime, capital account management, and interest rates are all still in the process of liberalization. China has maintained a de jure managed floating exchange regime with a narrow fluctuation band against the U.S. dollar since 1994. A decade-long current account surplus and the accumulation of foreign reserves have driven the RMB appreciation expectations, which further encouraged capital inflows. Figure 3 shows that "hot money," proxied by the "net errors and omissions," had been growing since the early 2000s. As a result, the money supply (M2) kept increasing, mainly driven by the accumulated foreign exchange reserves (Figure 4). In addition, capital controls prevented private capital from flowing to overseas markets, although the authorities had already eased their stance in the second half of the 2000s. ${ }^{9}$ This lack of capital outflow channels may have amplified the effect of a domestic credit boom. Table 5 illustrates that both indicators for China have been constantly maintained at a low level, indicating the existing tight capital controls. ${ }^{10}$

\footnotetext{
${ }^{9}$ China's liberalization policy changed to "relaxing outflows and tightening inflows" between 2006 and 2010 under the pressure of RMB appreciation. As a result of a significant increase in the surplus of both the current account and the capital account, huge foreign reserves and strong expectations of RMB appreciation became new challenges for China's government during this period. As a response, the authorities further moved to encourage outflows and tighten inflows. The main measures included (i) abolishing the limit on the amount of foreign exchange used in Chinese enterprises' direct investment abroad in 2006; (ii) allowing "Qualified domestic institutional investors" (QDIIs) to invest in overseas portfolios in 2006; (iii) and lowering the ceiling on banks' borrowing from abroad in 2007.

${ }^{10}$ Two common indicators of capital controls are the de jure Chinn-Ito index and the de facto openness index. The former presents the intensiveness of capital control regulation carried out by the authorities, while the latter measures the intensiveness of capital flows that actually occurred.
} 
Figure 3. Trends of Current Account, "Hot Money" and M2 in China, 2000-11

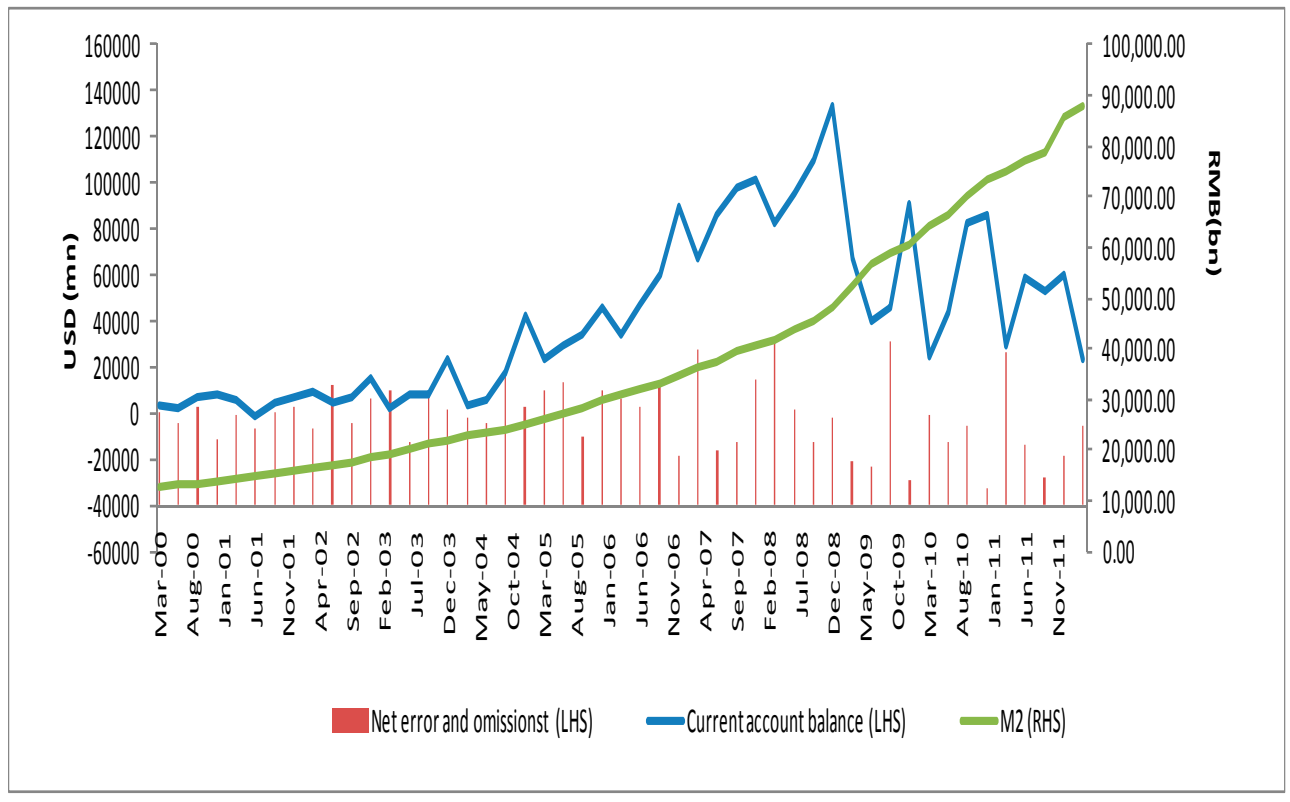

Source: CEIC and International Financial Statistics.

Figure 4. Exchange Rate of RMB, M2 and Foreign Reserves, 2000-11

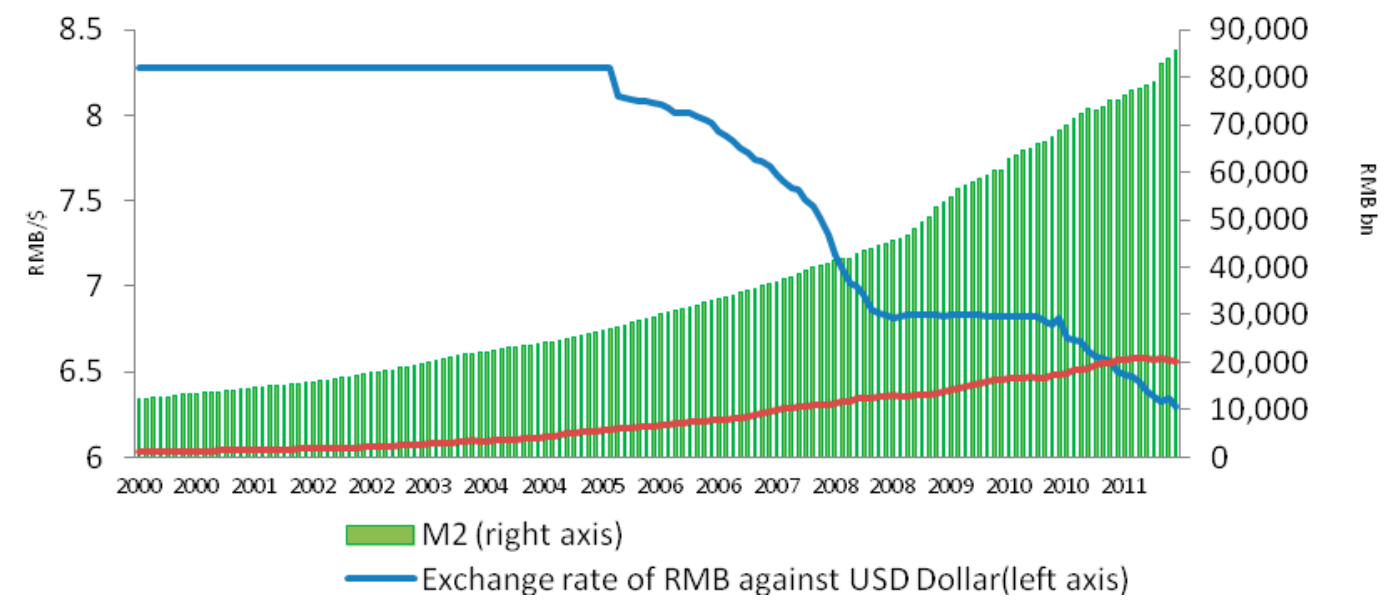

Source: CEIC. 
Table 5. Indicators of Capital Account Openness in China, 2005-10

\begin{tabular}{|l|r|r|r|r|r|r|}
\hline & 2005 & 2006 & 2007 & 2008 & 2009 & 2010 \\
\hline de jure-Chinn-Ito Index & -1.16 & -1.16 & -1.16 & -1.16 & -1.16 & -1.16 \\
\hline de facto-Openness Index & 0.92 & 1.04 & 1.09 & 0.89 & 0.82 & 0.76 \\
\hline
\end{tabular}

Source: http://web.pdx.edu/ ito/Chinn-Ito_website.htm and authors' estimates.

Note: Chinn-Ito index is an index measuring a country's degree of capital account openness. The higher the value is, the more open the country is to cross-border capital transactions. De facto-openness index is calculated as gross stocks of foreign assets and liabilities to GDP ratio. The higher this value is, the more open the capital account is.

Third, China's financial structure, which is dominated by the banking system with underdeveloped financial markets, can add to financial distortions. Banks are the key source of credit transmission in the Chinese economy. Their predominant role is reflected by their considerable size compared with the underdeveloped financial markets (Figure 5). The fiscal gap - the difference between local fiscal expenditure and revenue in percent of local fiscal revenue - is huge in some provinces (Figure 6). These differences can not only add to disparity and financial distortions, but also can make it very hard for the authorities to take synchronized and balanced policies to contain systemic risk.

Figure 5. Size of Selected Countries' Financial Systems, end-2011

(In percent of total)

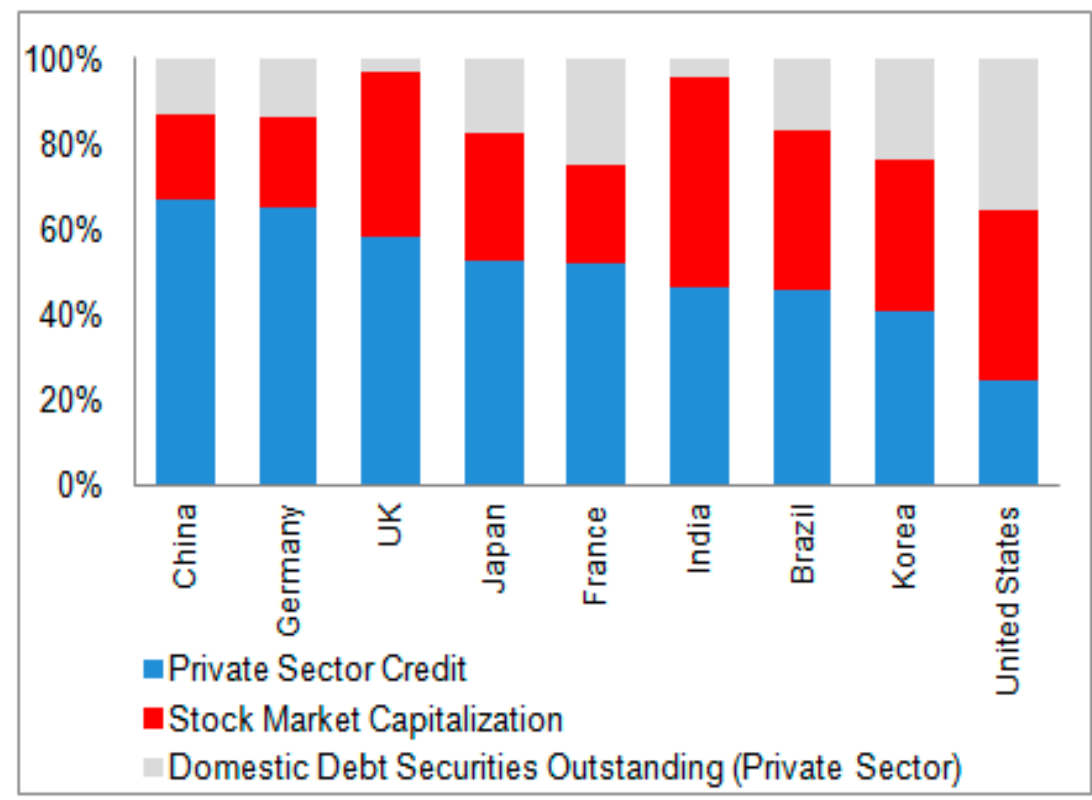

Source: Bloomberg; Bank for International Settlements; IMF, International Financial Statistics; and authors' estimates. 
Figure 6. Fiscal Gaps at Province Level in China

(In percent of revenue, 2006-11 annual average)

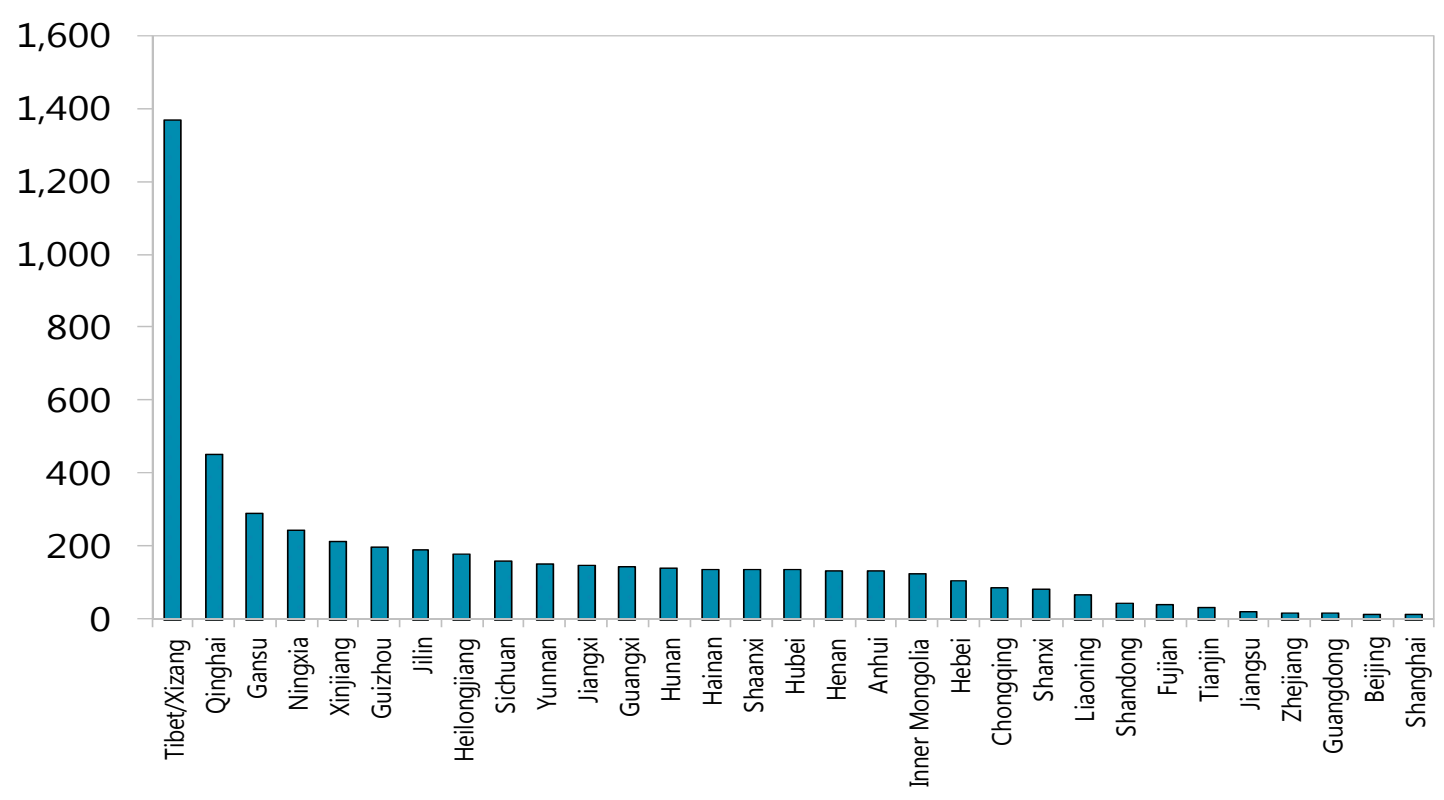

Sources: Haver Analytics; and authors' estimates.

Note: Fiscal gaps are the differences between local fiscal expenditure and fiscal revenue (excluding land sales revenues) in percent of local fiscal revenue.

\title{
B. Systemic Risk in China
}

\begin{abstract}
Both time dimension and cross-sectional systemic risk exists in China. First, systemic risk in the time dimension is on the rise owing to China's recent stimulus in response to the global financial crisis. China experienced an unprecedented surge in credit during 20082010 as a by-product of the authorities' policy response to the global financial crisis. China's central government launched a stimulus package with a total value of RMB 4 trillion in November 2008, in response to the slowdown in economic growth. Supported by the stimulus, local governments collected financial resources through, for instance, local government financing platforms (LGFPs), in support of local economies. Both domestic and global experience suggests that this type of credit-driven stimulus is likely to worsen credit quality and thus negatively impact China's financial stability. ${ }^{11}$ A comparison of credit expansion indicates that China is in a risky position. Recent credit expansion in China is one of the highest in the five housing boom episodes, and close to that of Hong Kong SAR before the 1997 Asian financial crisis (Figure 7).
\end{abstract}

\footnotetext{
${ }^{11}$ IMF (2011b) shows that credit growth and asset price growth together form powerful signals of systemic risk buildup as early as two to four years in advance of crises.
} 
Figure 7. Credit Comparison: Five Years Before Housing Price Peaks

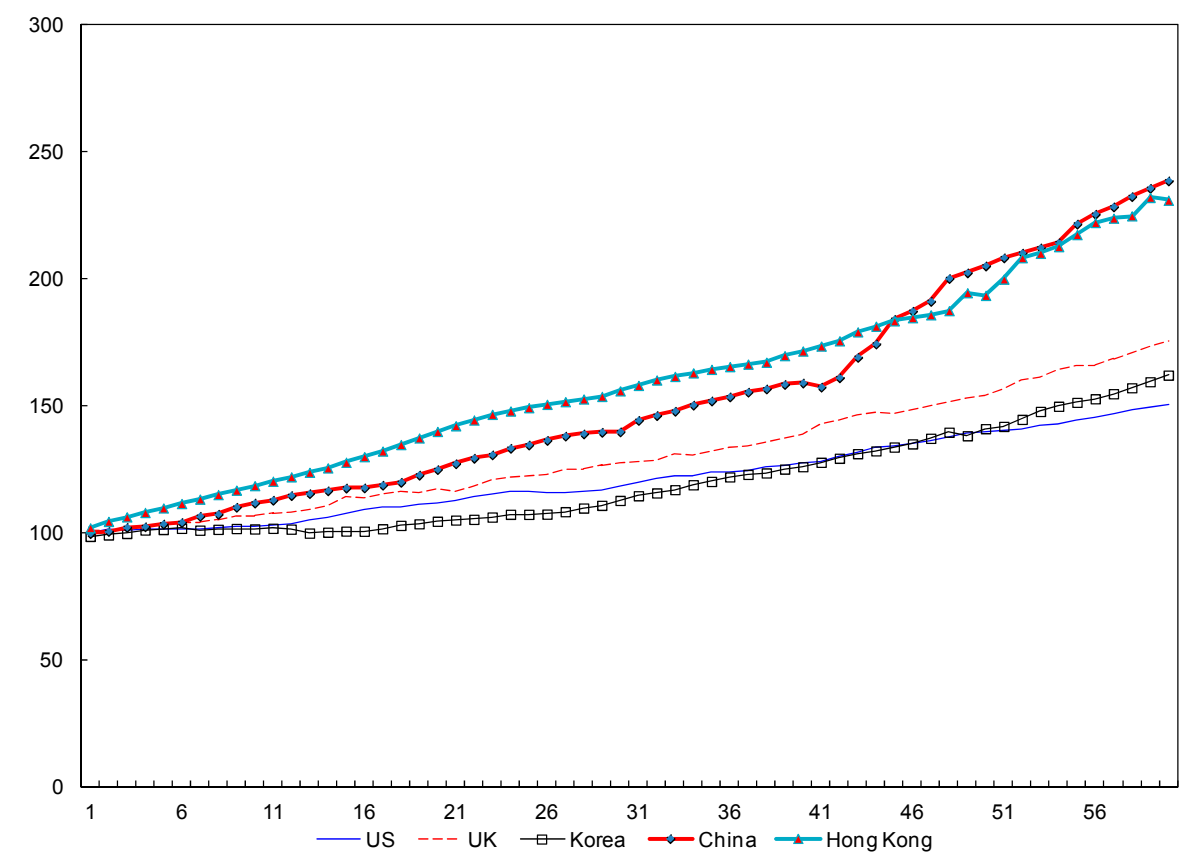

Sources: Haver Analytics; International Financial Statistics; and authors' estimates.

Note: The figure captures the credit increases 60 months before the house price peak in each economy. The value of first month is taken as bench mark to calculate other values in the following months. The period is July 2001-July 2006 (U.S.), October 2002-October 2007 (U.K.), October 2002-October 2007 (Korea), June 2005-June 2010 (China), and October 1992-October 1997 (Hong Kong, SAR).

\section{Second, as a consequence of the credit expansion, a potential bubble in asset markets,} particularly in the housing market, has become a natural by-product of current economic imbalances and incomplete financial deregulation. The rapid expansion in credit further underscores the overheating concerns about China's house prices. With relatively low and occasional negative real deposit rates, large volatilities in the equity market, and RMB appreciation expectations, along with capital controls, savings flocked to the real estate market, thus triggering boom in house prices (Figure 8). Compared with other countries, house prices in China have increased more rapidly than during the housing booms in Korea, the U.K., and the U.S. (Figure 9). Obviously, there has been a strong pro-cyclical dimension of systemic risk in the Chinese economy, with easy credit and a high-risk appetite fuelling the kinds of exuberant behavior in asset markets that can prove so damaging to the financial system if left unchecked. 
Figure 8. Mortgages and House Prices in China, 2008-10

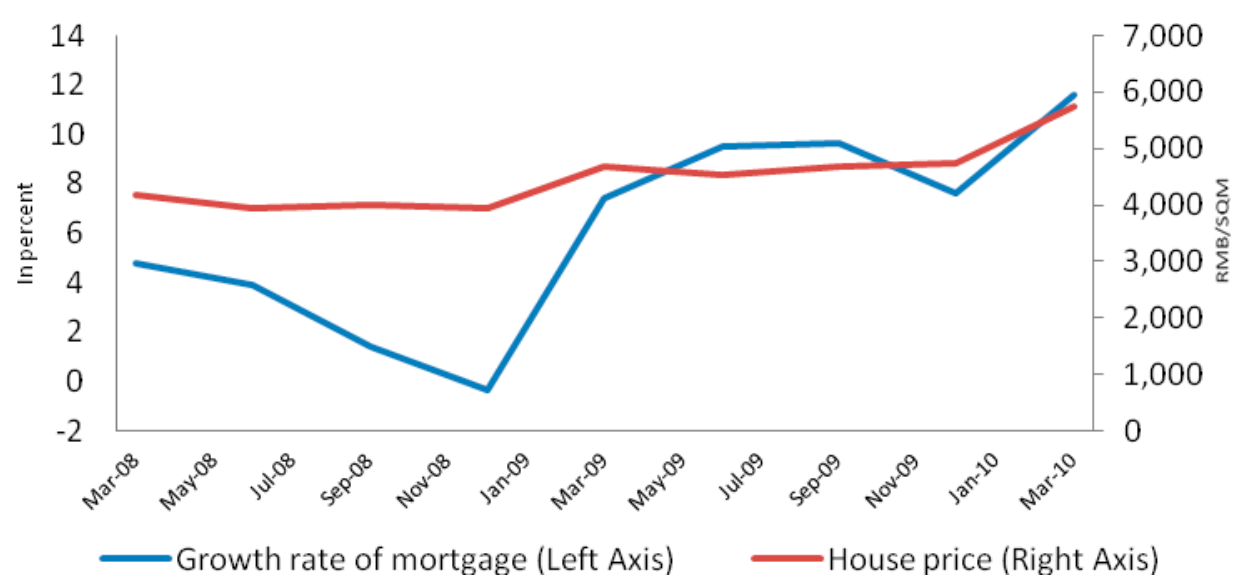

Source: CEIC.

Figure 9. Comparing China's Housing Price Increases with

Those in Other Housing Booms

(Indices rebased on house prices 60 months before the peak)

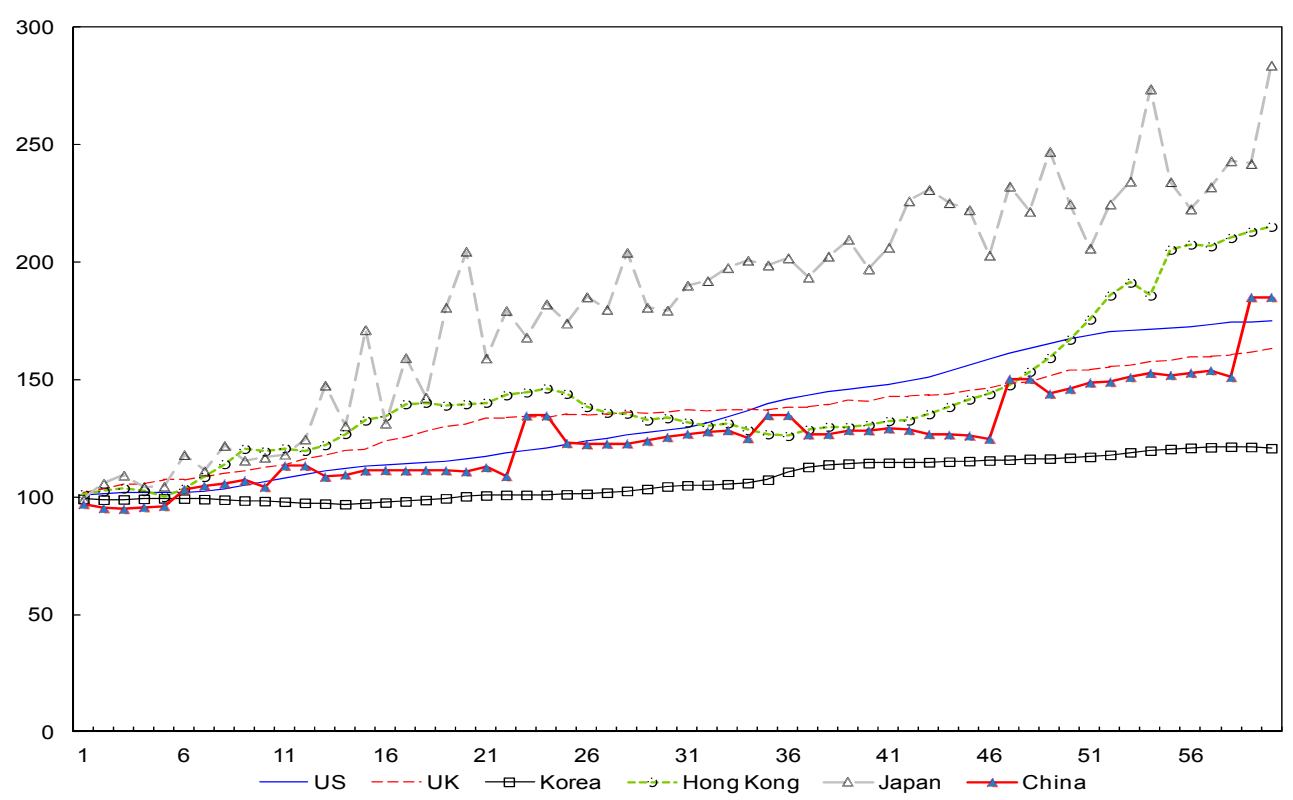

Sources: Haver Analytics; International Financial Statistics; and authors' estimates.

Note: The figure captures house price increases 60 months before the peak in each economy. The value of first month is taken as bench mark to calculate other values in the following months. The periods were July 2001-July 2006 (U.S.), October 2002-October 2007 (U.K.), October 2002-October 2007 (Korea), October 1992-October 1997 (Hong Kong SAR), February 2005-February 2010 (China), and May 1986-May 1991 (Japan). 
Third, the complexity of the financial system is rapidly increasing in China. The rapid increase in the size and complexity of the financial system, including informal financing and LGFPs, could generate forms of interconnectedness and common exposures conducive to the rapid contagion of risk when problems arise. Figure 10 demonstrates the rapid development of informal financing, which accounts for over 20 percent of total social financing in late 2012. Figure 11 shows that loans borrowed by LGFPs outweigh the local fiscal revenues in most provinces in 2009 , though some credit lines may not be fulfilled as a result of the policy tightening in 2011. Interlinkages are intensifying in the form of cross-market linkages, ${ }^{12}$ cross-institution linkages, ${ }^{13}$ and external financial linkages. ${ }^{14}$

Figure 10. Informal Financing in China

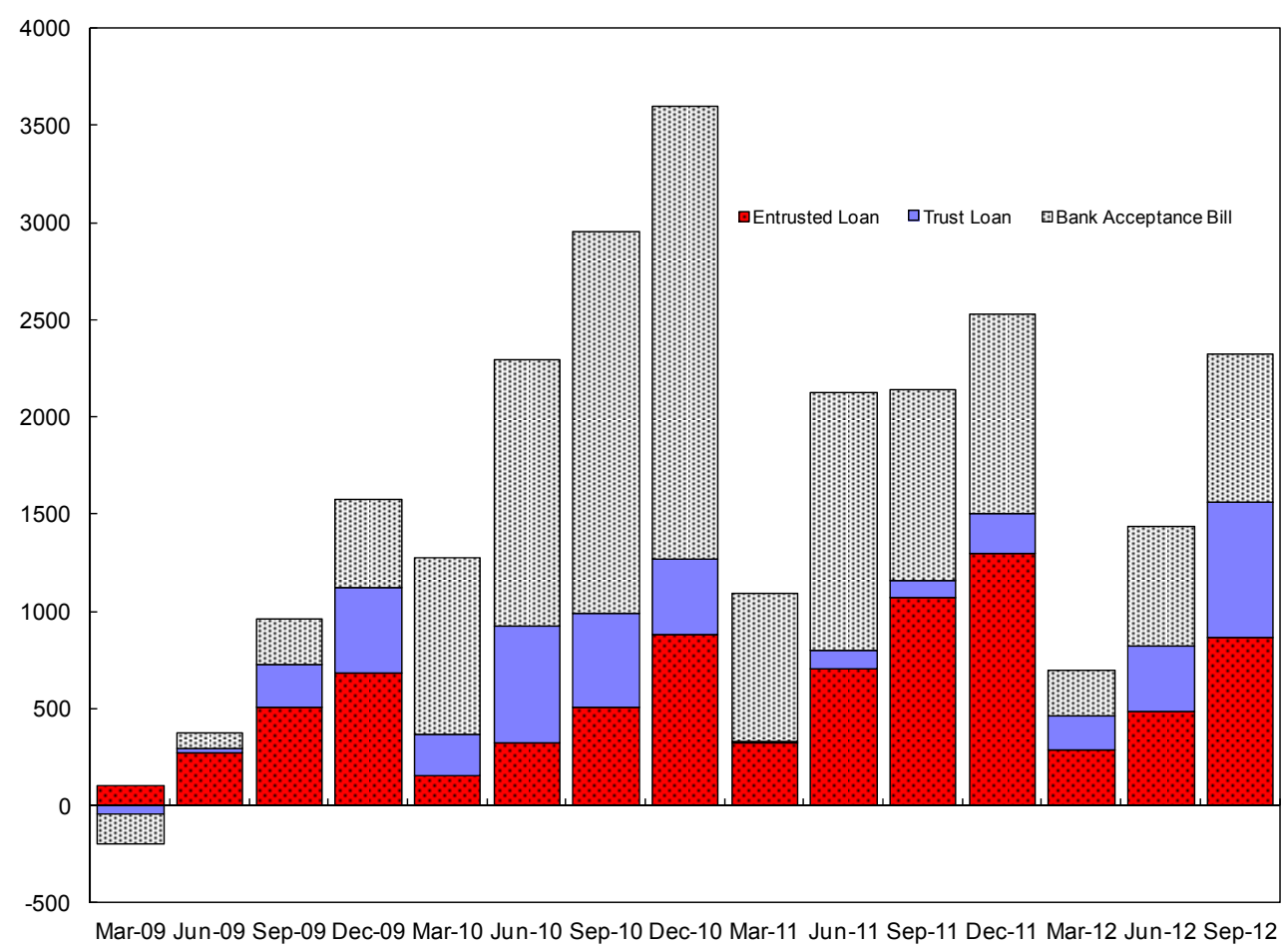

Sources: Haver Analytics; International Financial Statistics; authors' estimates.

\footnotetext{
${ }^{12}$ Cross-market linkages refer to the linkages between the money market, bond market, foreign exchange market, and equity market.

${ }^{13}$ Cross-institution linkages refer to the linkages between banking and nonbanking institutions, financial institutions and non-financial corporations.

${ }^{14}$ External financial linkages refer to the linkages associated with global liquidity spillovers, investment and exposure to global financial assets, spillovers in equity markets and sovereign Credit Default Swap (CDS) markets, Chinese bank system's linkages with the rest of the world, international business cycle risk, and default spillovers.
} 
Figure 11. Loans by Local Government Financing Platforms Outweigh Local Government Revenue

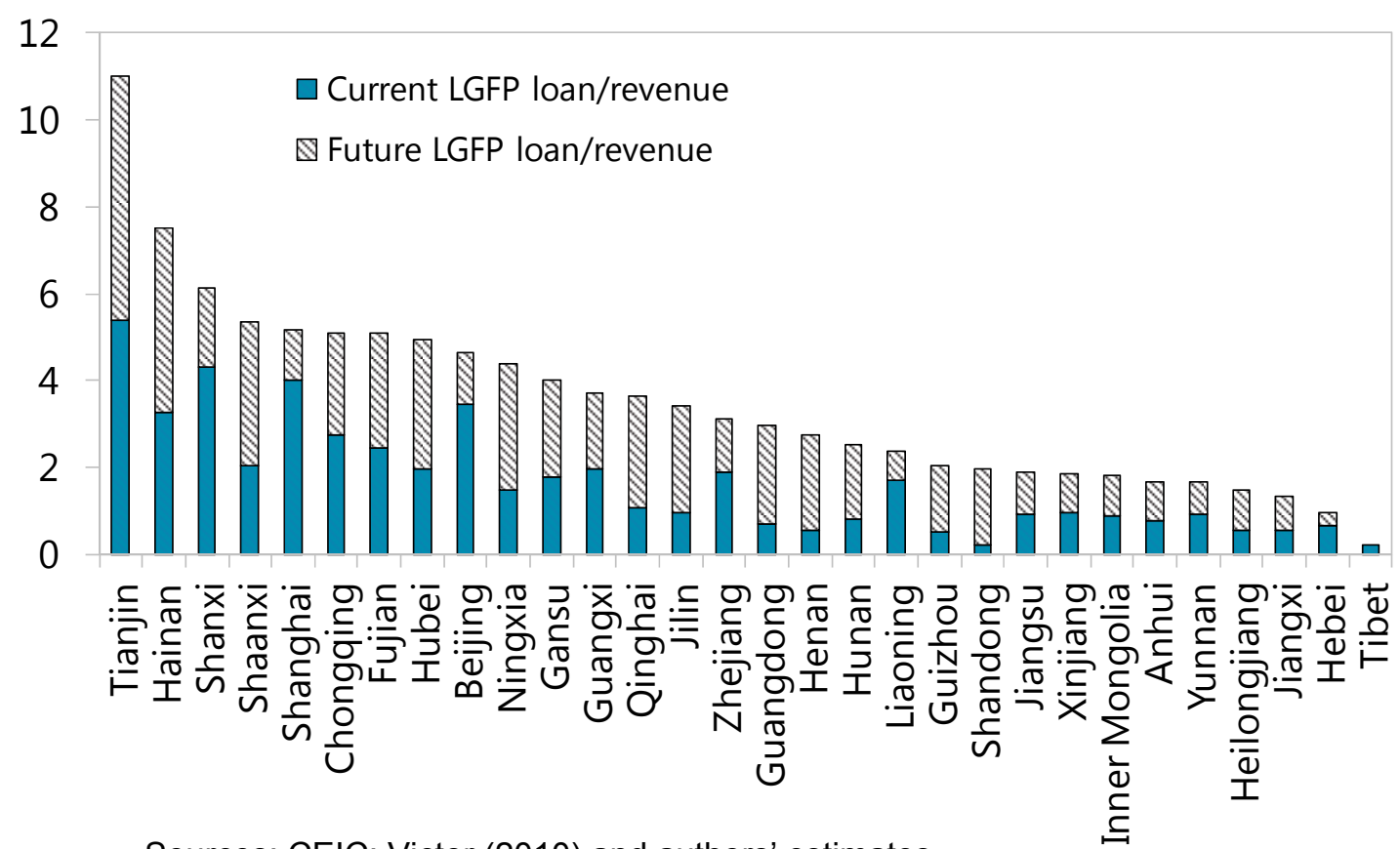

Sources: CEIC; Victor (2010) and authors' estimates.

In sum, three major factors have contributed to the possible increases in systemic risk in China. First, the relatively loose monetary policy and fiscal stimulus during the financial crisis have encouraged credit expansion. Second, the macroeconomic and financial environment, including the yet-to-be finished interest rate and exchange rate liberalization, may have contributed to liquidity and credit expansion. Third, the bank-dominated financial system and relatively limited capital account openness have further added to the credit expansion and house price increases. The combined forces have generated significant downside risks in the form of excessive credit expansion, overcapacity, a capital-intensive means of production, a tendency for asset bubbles, and a periodic need for public-funded bank recapitalizations.

Therefore, this paper takes credit and asset prices as the major proxies for systemic risk in China. Global experiences show that credit and asset prices are the two most powerful signals of systemic risk buildup as early as two to four years in advance of crises IMF (2011a and 2011b). In the case of China, the credit-fueled investment boom since the 2007 global crisis has given rise to concern about a possible deterioration in banks' asset quality and asset price deviations. It is exactly this serious concern that prompted the Chinese authorities to introduce a set of policies, including macroprudential measures, to mitigate the possible systemic risk. In addition, credit expansion has been extensively linked to other parts of the financial sector, such as informal financing and LGFPs. 
Therefore, finding a balanced way to contain potential systemic risk in China is particularly important in the context of globalization and monetary easing in the major advanced economies, in particular. With the growing openness and RMB appreciation expectations, increases in the monetary policy rate will tend to attract more capital inflows and lead to a further appreciation of the currency. Therefore, a tightening of macroprudential policies, such as continuous increases in the RRR, can reduce excessive credit growth without attracting more capital inflows and appreciating the exchange rate. Dampening capital inflows would, in turn, give greater room for maneuver for monetary policy.

\section{Stylized Facts on Macroprudential Policies and Their EfFectiveness}

This section first summarizes the macroprudential policy toolkit and institutional setup in China. Then it briefly discusses some stylized facts concerning the macroprudential policy toolkit and the effectiveness of the policies.

\section{A. China's Macroprudential Policy Toolkit}

The Chinese authorities have implemented some macroprudential policies to address systemic risk. The policy instruments were implemented with the aim of curbing the credit boom and the increase in house prices, while at the same time avoiding cross-sectional dimension systemic risk (Table 6).

Table 6. China's Macroprudential Policy Instruments

\begin{tabular}{|l|l|}
\hline \multicolumn{1}{|c|}{ Instruments } & \multicolumn{1}{|c|}{ Authorities } \\
\hline \multicolumn{2}{|c|}{ Time-dimension risks } \\
\hline $\begin{array}{l}\text { Dynamic adjustment of the } \\
\text { differentiated reserve } \\
\text { requirement ratio }\end{array}$ & People's Bank of China \\
\hline $\begin{array}{l}\text { Dynamic LTV requirement for first } \\
\text { homes and second homes }\end{array}$ & $\begin{array}{l}\text { People's Bank of China; China Banking } \\
\text { Regulatory Commission }\end{array}$ \\
\hline $\begin{array}{l}\text { Dynamic provisioning } \\
\text { requirement }\end{array}$ & China Banking Regulatory Commission \\
\hline Countercyclical capital buffer & $\begin{array}{l}\text { People's Bank of China; China Banking } \\
\text { Regulatory Commission }\end{array}$ \\
\hline \multicolumn{1}{|c|}{ Cross-sectional dimension } \\
\hline Capital surcharge for SIFls & $\begin{array}{l}\text { People's Bank of China; China Banking } \\
\text { Regulatory Commission }\end{array}$ \\
\hline Capital conservation buffer & China Banking Regulatory Commission \\
\hline Leverage ratio requirement & China Banking Regulatory Commission \\
\hline Liquidity surcharge & China Banking Regulatory Commission \\
\hline Enhancing supervision for SIFls & China Banking Regulatory Commission \\
\hline Early warning system & $\begin{array}{l}\text { People's Bank of China; China Banking } \\
\text { Regulatory Commission }\end{array}$ \\
\hline
\end{tabular}

Source: China Monetary Policy Report (2011 Q4) and Liao Min, 2012, "The Framework to Monitor and Assess the Systemic Risk—China's Practice," https://www.imf.org/external/np/seminars/eng/2012/macroprudential/. 
The People's Bank of China (PBC) developed a macroprudential policy instrumentthe "dynamic adjustment of the differentiated reserve requirement."

- Differentiated reserve requirement: Taking the $\mathrm{RRR}$ as a traditional instrument of monetary policy, the PBC launched the "differentiated reserve requirement" in 2004 to inhibit the expansion of loans by financial institutions with a low CAR and the deterioration of asset quality. The purpose was to reduce credit within the financial system by decreasing the amount of loans and increasing the reserves of those banks with a CAR of less than 4 percent.

- Dynamic adjustments to the differentiated reserve requirement: In 2011, the PBC dynamically adjusted the differentiated reserve requirement on a continuous and caseby-case basis to enhance macroprudential regulation in response to the credit risk.

The formula for calculating this ratio is as follows:

Ratio $=$ the robust parameter * (the required CAR - the actual CAR),

where the required CAR is equal to the regulatory minimum CAR ( 8 percent), plus a countercyclical capital buffer and capital surcharge for SIFIs. The robust parameter is based on the all important indicators of a bank itself, such as its liquidity position, leverage ratio, provisioning, credit rating, level of management of internal risks, payment and settlement cases, and implementation of the credit policy. This instrument helps to incentivize financial institutions to maintain robustness and guide them as they exercise a certain degree of flexibility in making adjustments to their expansion of credit. As shown in Figure 12, the PBC used different RRRs for large banks and small/medium banks, and has raised the RRRs since 2010 to absorb the liquidity in the financial system.

Figure 12. RRRs of China's Large Banks and Small/Medium Banks, 2008-12

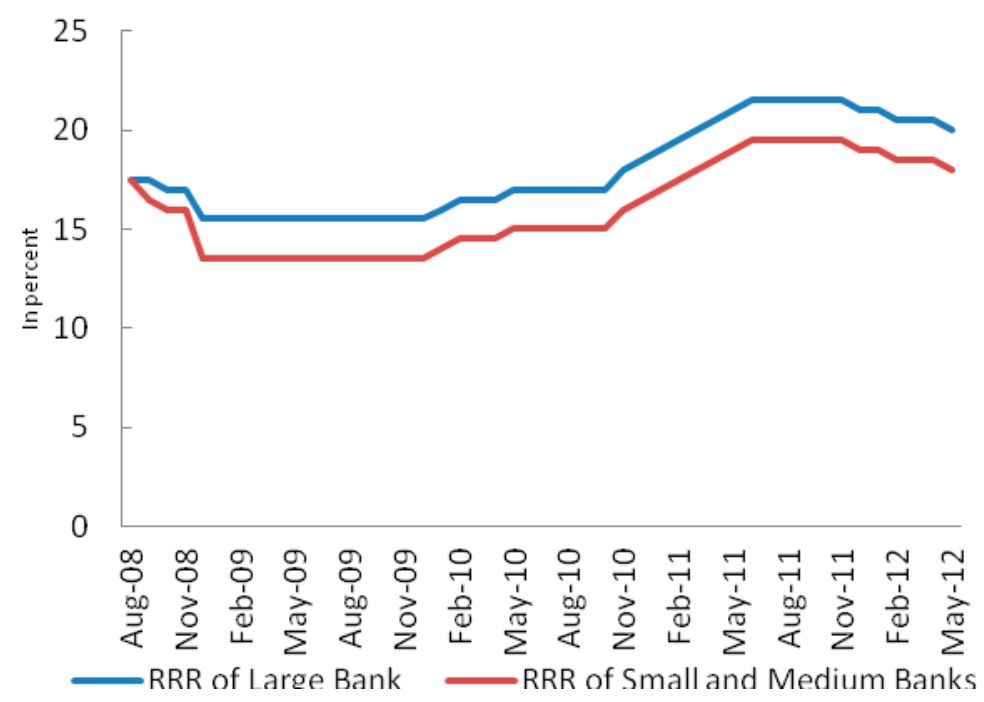

Source: CEIC. 
The China Banking Regulatory Commission (CBRC) also established five macroprudential instruments, taking into consideration the specific characteristics of China's financial institutions. Specifically, the CBRC launched the following five instruments in 2011:

- $\quad$ Revised CARs: In addition to the minimum requirements of core tier 1 CAR, tier $1 \mathrm{CAR}$, and total CAR — which have been adjusted to 5 percent, 6 percent, and 8 percent, respectively_banks need to set aside excess capital to absorb losses arising from the business cycles. This includes a permanent capital conservation buffer of 2.5 percent, a countercyclical capital buffer of 0 to 2.5 percent in cases of rapid loan growth that may generate systemic risk, and a 1 percent capital surcharge imposed on the five largest banks owing to their systemic importance. Accordingly, the total CAR for the systemically important banks has increased to 11.5 percent (from 8 percent), and to 10.5 percent for the other banks.

- $\quad$ A new provisioning requirement: Banks need to meet the tighter of the following two requirements: a provisions-to-loans ratio (the proportion of loan loss provisions to total loans) not lower than 2.5 percent; or a provisions coverage ratio not lower than 150 percent (changed from 100 percent). This rule has been in effect since January 1, 2012, stipulating that systemically important banks and non-systemically important banks should be in compliance before 2013 and 2016, respectively.

- $\quad$ A new leverage ratio: This ratio should not be lower than 4 percent. The rules, issued in 2011, provide that systemically important banks and non-systemically important banks should meet the requirement before 2013 and 2016, respectively.

- Liquidity indicators: the indicators of the liquidity coverage ratio (LCR) and net stable funding ratio (NSFR) are set at not less than 100 percent for banks. These indicators have been monitored since 2009 and will be binding in 2013.

- $\quad$ Adjustments to the LTV ratio: The LTV ratio has been adjusted several times since 2007 to contain the risk of an unsustainable real estate boom (Table 7). 
Table 7. LTV Ratio in Chinese Real Estate Sector

(In percent)

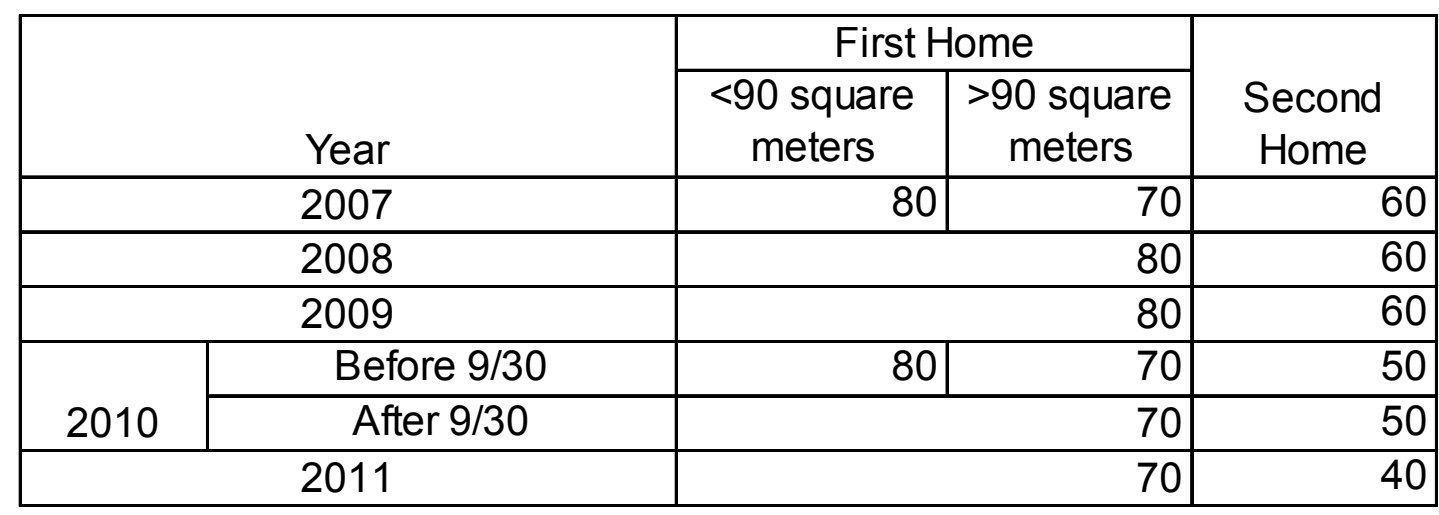

Source: China Monetary Policy Report (2011 Q4) and Liao Min (2012).

\section{B. China's Macroprudential Institutional Arrangement}

China's current institutional framework for financial stability comprises three levels: (i) high level—regular meetings chaired by the State Council; (ii) middle level—including monetary policy committee meetings and quarterly meetings of the supervisory authorities. The financial regulatory agencies regularly coordinate actions and communicate on major issues, such as financial stability, financial reform, risk mitigation; and (iii) low levelcommunication between the regulators and the regulated institutions. While the overarching responsibility for financial stability resides with the State Council, the Law on the People's Bank of China as amended in 2003 entrusts the PBC with the important responsibilities of guarding against and eliminating systemic financial risk and maintaining financial stability. This responsibility was exercised during the global financial crisis by establishing and chairing a high-level committee of the key financial agencies that met regularly to assess conditions and consult on policy actions. Each of the agencies also has contingency plans in place for responding to a crisis, including MOUs to promote cooperation. However, one of the vital lessons of the global financial crisis is that inter-agency cooperation must be equally effective outside crisis periods, so that any build-up of risks can be identified and addressed well before they crystallize as a systemic event. In other words, an effective macroprudential policy framework is one in which financial agencies not only share their concerns on emerging risks but work closely together to resolve them. 


\section{Stylized Facts on the Effectiveness of China's Macroprudential Policies}

In 2010 and 2012, the authorities introduced several macroprudential policy measures to contain excessive growth in credit and house prices.

- $\quad$ The PBC raised the RRR twelve times by a total of 600 basis points between January 2010 and June 2011 (Figure 13).

- The PBC used "dynamic adjustments to the differentiated reserve requirement" since 2010 to guide financial institutions toward greater robustness in their operations and to encourage them to upgrade their capacity to mitigate risk.

- $\quad$ The CBRC launched macroprudential instruments to simultaneously improve financial stability. For example, the CBRC employed a strong provisions-to-loans ratio to lower the amount of poor quality loans.

Figure 13. Loan Growth Rate Decreases and Increases in Lending Rate and RRR (2010-12)

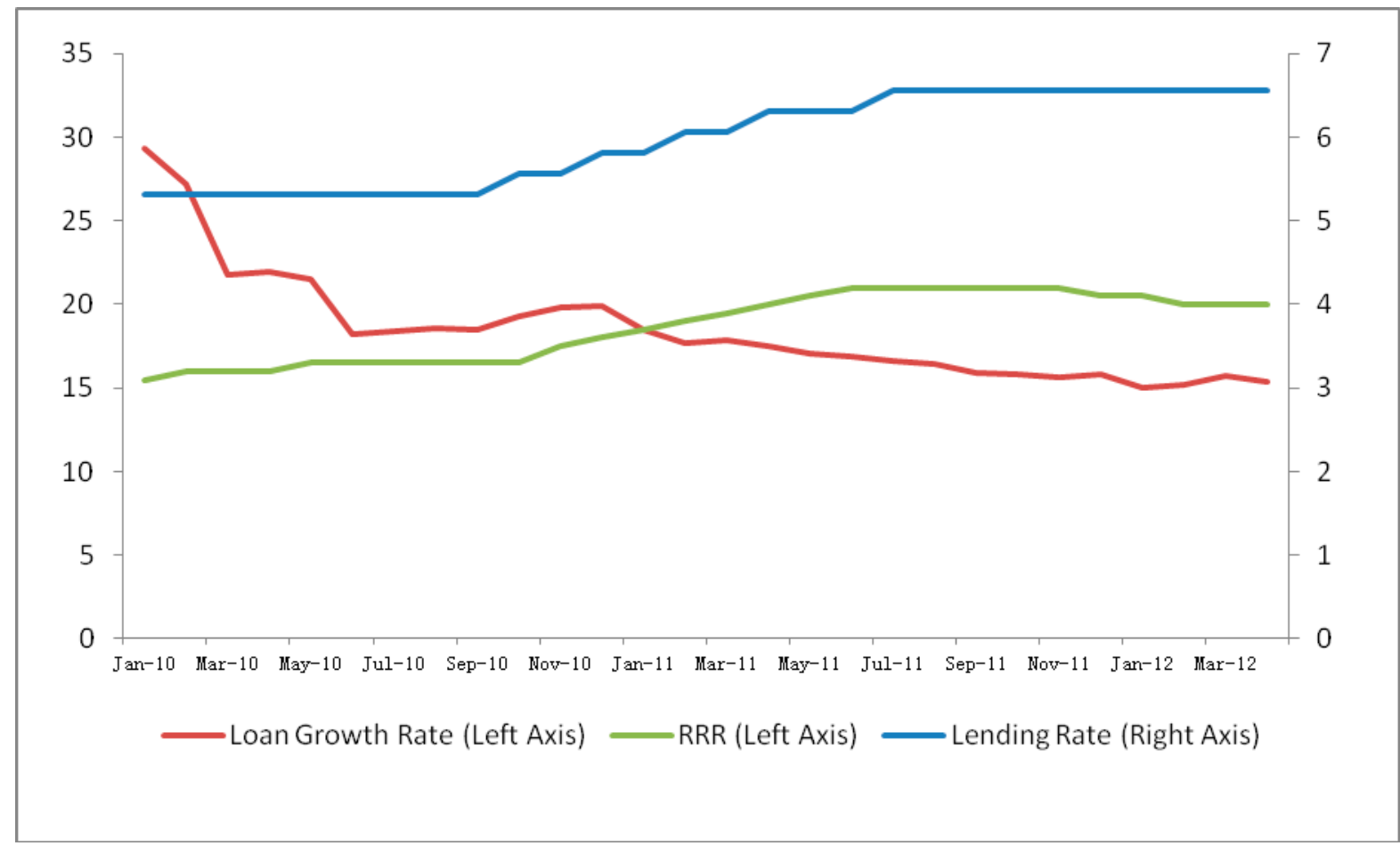

Source: CEIC.

These macroprudential policy tools targeting credit growth are proving to be effective in dampening the credit boom. The growth rate of domestic credit was kept low in 2010 and 2011. This is in sharp contrast to the dramatic increase between 2008 Q4 and 2009 Q3, 
suggesting that the macroprudential instruments are having the desired effect. Figure 14 illustrates that the credit to GDP ratio rapidly increased after 2008 Q4 and exceeded the threshold for the launching of counter-cyclicality buffers (i.e. 2 percent) by 2009 Q2. This ratio was brought below the benchmark by 2011 Q3, which confirms that the macroprudential policy tools have been effective in addressing systemic risk.

Figure 14. China: Interest rate, RRR, and Quarterly Growth in Domestic Credit, 2000Q1-2011Q4

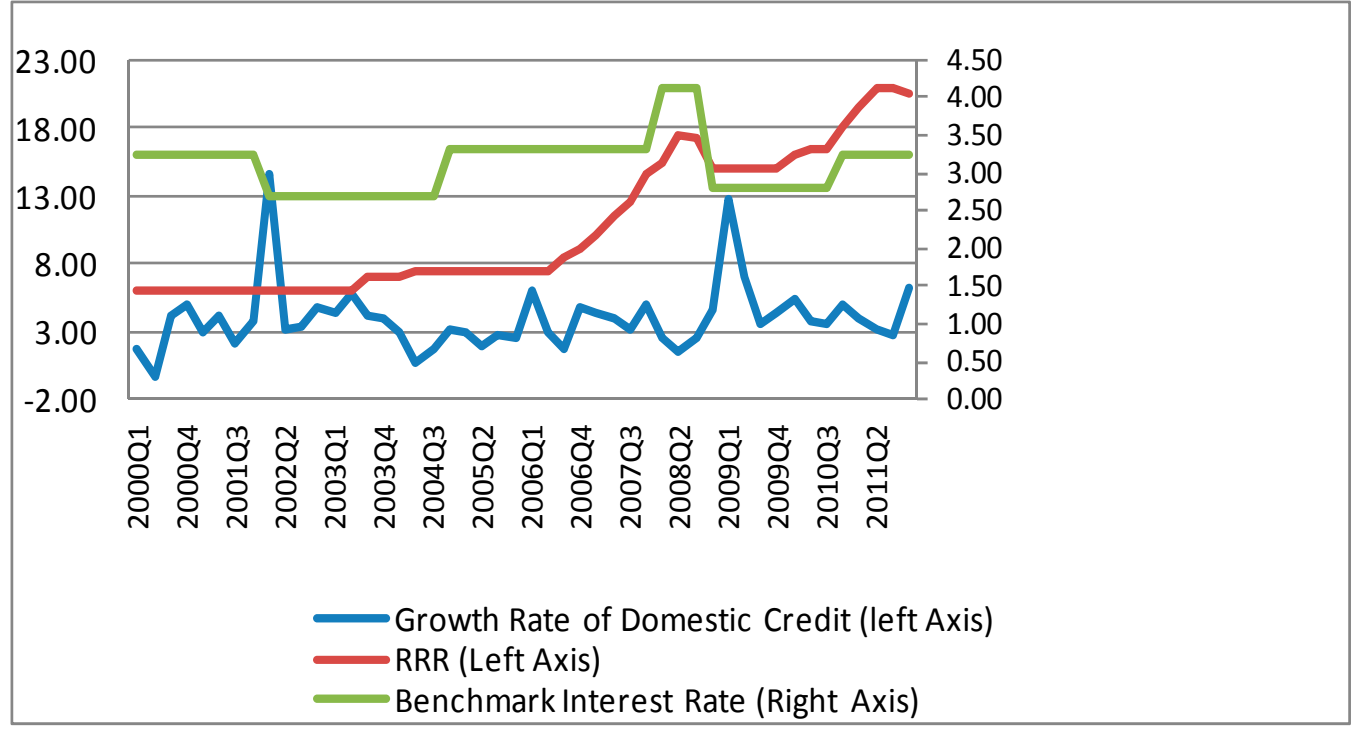

Source: International Financial Statistics and authors' estimates.

To address overheating in the housing market, the authorities employed a policy package, including macroprudential policies, to reduce speculative demand in the housing market. From 2010 to 2012, besides consistently raising the RRR, the authorities lowered the caps on the LTV ratio, disallowed mortgages for third homes, and raised interest rates on mortgages for second homes (Table 7).

The RRR is being used as a tool for both monetary policy and macroprudential policies. On the one hand, the RRR is used to sterilize reserve money accumulation resulting from the rapid growth in FX reserves. On the other hand, RRR changes are also used as a macroprudential policy instrument. For instance, the announcement in August 2011 included margin deposits (deposits as collateral for letters of credit, bank acceptances, and letters of guarantee) in reserve requirements. The motivation was to remove the arbitrage opportunity in these business areas, as margin deposits had been included in loan-to-deposit calculations but excluded in RRR calculations. The RRR has therefore become an important macroprudential policy tool in China because it allows continuous and dynamic changes in response to economic and financial conditions. 
The preliminary effects on the housing market can be observed. For instance, Figure 15 illustrates that mortgages significantly decreased between 2010 and 2011, and the trend of rising house prices was restrained following implementation of these instruments (Figure 16). This suggests that macroprudential instruments have had the intended effect of reducing house prices.

Figure 15. Mortgages and House Prices in China, 2010-11

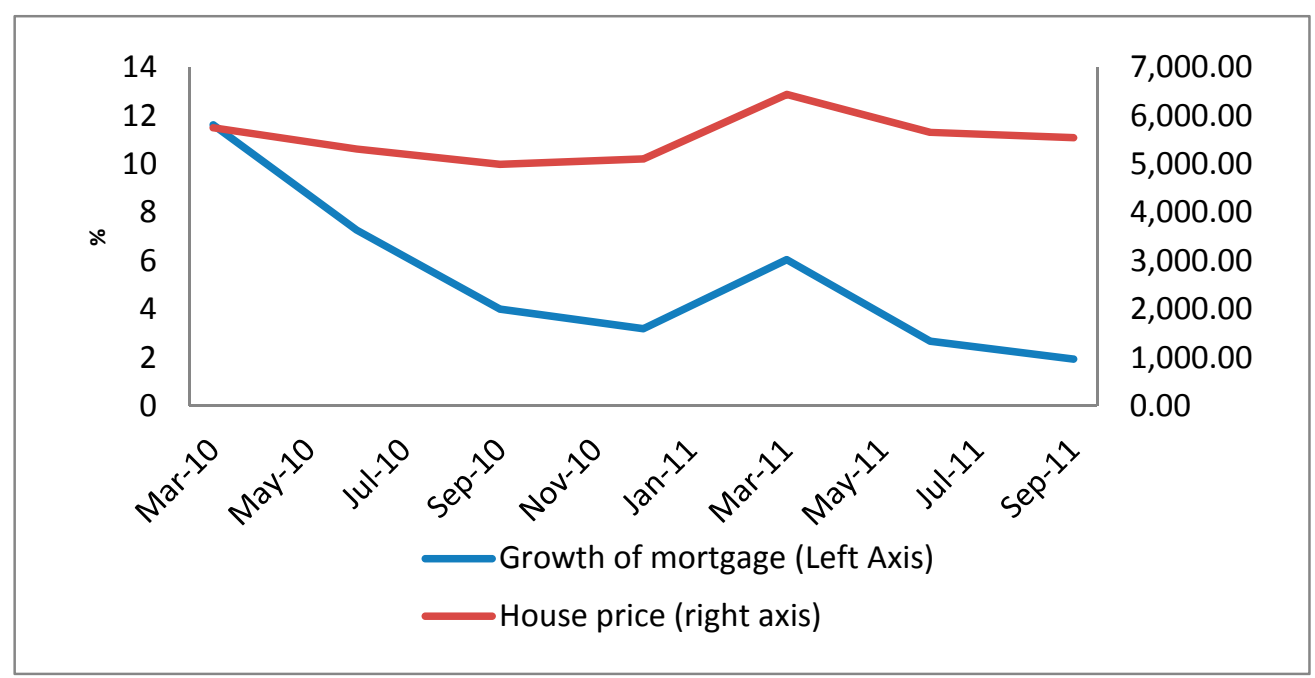

Source: CEIC.

Figure 16. House Prices and Policy Impact

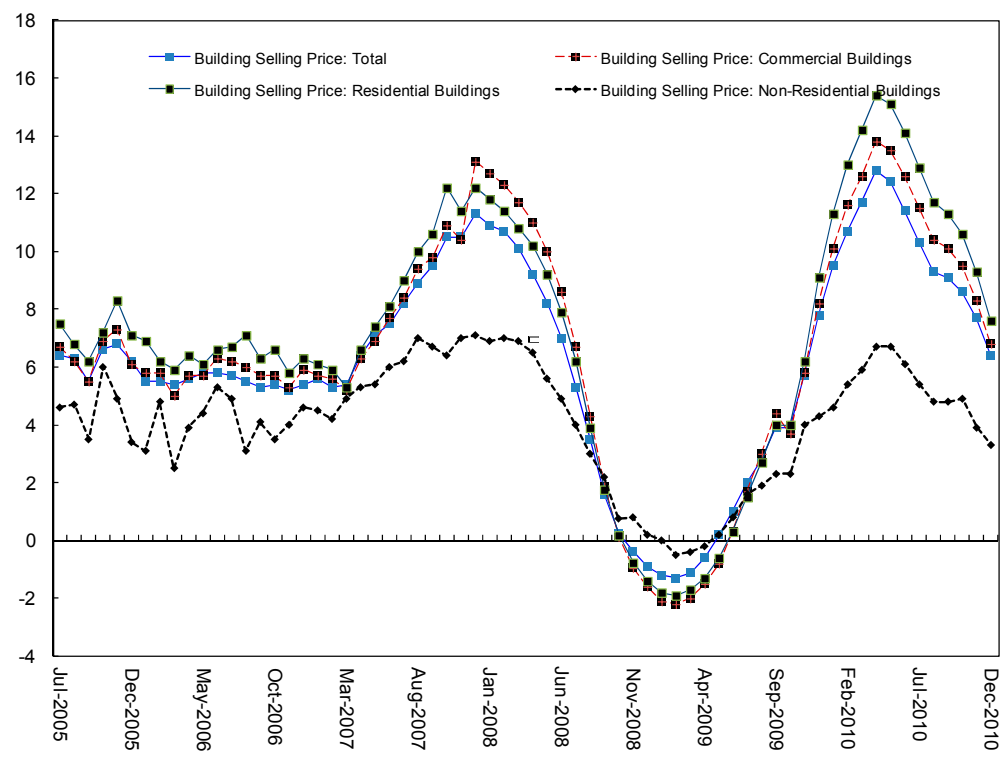

Source: CEIC. 
Macroprudential policies may work through two channels. One is the expectations channel: tightening measures curbed expectations about future gains from housing price appreciation, which reduced housing demand and alleviated pressures on house prices. The other is the liquidity constraint channel. For instance, an increase of 0.5 percent in the RRR would reduce by over RMB 300 billion the available liquidity in the banking system, affecting especially those small and medium-sized banks that have a constant demand for liquidity in the market. It should be noted, however, that owing to the effectiveness of these policies and concerns about a potential economic slowdown, the authorities have reversed some measures since 2011 (Table 8). Figure 17 summarizes the rationale for the introduction of macroprudential policies in China.

\section{The effectiveness of macroprudential policies is also subject to their interplay with} monetary policy in China. On the one hand, the current monetary policy framework and financial market development have created a tremendous need for and challenges to macroprudential policies. For instance, the low interest rates and credit stimulus have encouraged risk-taking; the current account surplus, inflexible exchange rate, and RMB appreciation expectation have flooded the economy with excess liquidity; and the underdevelopment of financial markets has promoted the flow of a huge amount of liquidity into the housing market. On the other hand, macroprudential policies have alleviated some pressures. For instance, the increases in the RRR may help drain liquidity from the market and dampen expectations of house price increases, the higher capital requirements can contain the increases in bank leverage, and the LTV ratio may tame house prices. However, macroprudential policies alone cannot be expected to contain all systemic risk arising from constrained monetary policy and underdeveloped financial markets. 


\section{Table 8. Instruments for Curbing China's House Prices}

\begin{tabular}{|c|c|}
\hline \multicolumn{2}{|c|}{ Macroprudential policy } \\
\hline April 2010 & $\begin{array}{l}\text { Caps on the LTV were lowered from } 80 \text { percent to } 70 \text { percent for primary homes and to } \\
50 \text { percent for second homes. }\end{array}$ \\
\hline April 2010 & $\begin{array}{l}\text { Interest rates on mortgages for second homes were raised to } 1.1 \text { times the officially } \\
\text { administered benchmark lending rate. }\end{array}$ \\
\hline October 2010 & Mortgages for third homes were suspended. \\
\hline January 2011 & The LTV cap on second home mortgages was lowered to 40 percent. \\
\hline 2010-2011 & $\begin{array}{l}\text { The reserve requirement was raised twelve times for a total of } 600 \text { basis points } \\
\text { between January } 18,2010 \text { and June } 20,2011 \text {. }\end{array}$ \\
\hline 2011-2012 & $\begin{array}{l}\text { The reserve requirement was decreased three times for a total } 150 \text { basis points during } \\
\text { the period December } 5,2011 \text {-May } 18,2012 \text {. }\end{array}$ \\
\hline \multicolumn{2}{|l|}{ Monetary policy } \\
\hline $2010-2011$ & $\begin{array}{l}\text { The official benchmark lending rate was raised five times between October } 2010 \text { and } \\
\text { July } 2011 \text { for a total of } 125 \text { basis points. }\end{array}$ \\
\hline 2012 & $\begin{array}{l}\text { The official benchmark lending rate was decreased two times from June } 7,2012 \text { to } \\
\text { July } 5,2012 \text { for a total of } 56 \text { basis points. }\end{array}$ \\
\hline \multicolumn{2}{|l|}{ Fiscal policy } \\
\hline January 2010 & Taxes were increased on the resale of properties within five years of purchase. \\
\hline September 2010 & $\begin{array}{l}\text { The exemptions of home purchases from stamp duty and of home sales from income } \\
\text { tax were abolished for all transactions except for cases involving a family's only home. }\end{array}$ \\
\hline January 2011 & $\begin{array}{l}\text { Business tax ( } 5.5 \text { percent) will be levied on } 100 \text { percent of the sales proceeds if } \\
\text { holding period is less than } 5 \text { years (previously was levied on capital gains only). }\end{array}$ \\
\hline January 2011 & Shanghai, Chongqing launch property \\
\hline
\end{tabular}

Source: Lim and others (2011); The PBC and CBRC.

\section{Figure 17. Understanding the Rationale of Macroprudential Policies in China}

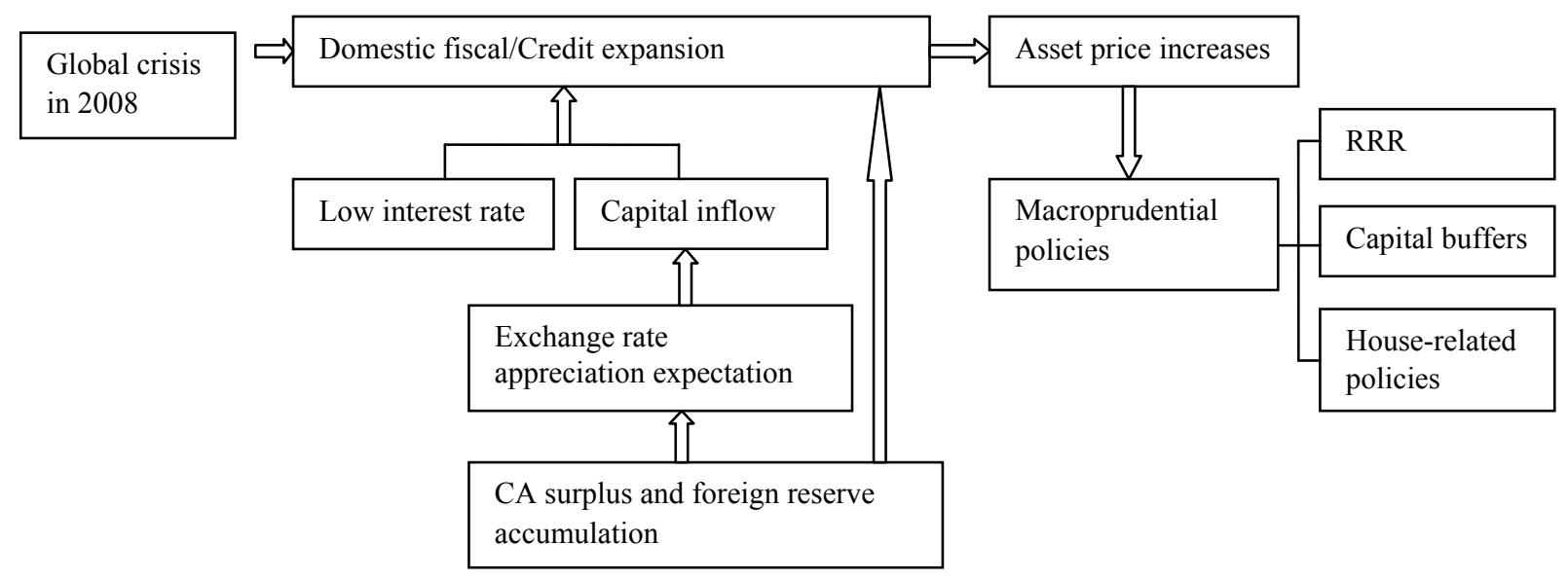

Source: Authors. 


\section{EfFectiveness of Macroprudential Policies-An Empirical ANalysis}

This section empirically investigates the effectiveness of macroprudential policies in addressing systemic risk. Investigating the effectiveness of macroprudential policies in China is a daunting challenge. The hard-to-capture financial stability and limited quantitative knowledge on the effects of macroprudential policies make macroprudential policies imperfect (IMF, 2012). In the case of China, the three features - economic imbalances, stillin-progress financial liberalization, and unbalanced financial structure - make it even harder to definitely identify the effects of macroprudential policies. The paper, following the literature and China-specific circumstances, takes excessive credit expansion and asset price increases as measures of systemic risk to explore the effectiveness of major macroprudential policies. Specifically, this section explores:

- The relationship between individual policies (including macroprudential policies, monetary policy, and housing-related policy) and two proxies for systemic riskincreases in credit and house prices;

- The relationship between individual policies, in so far as they affect the growth in loans and house prices; the size of the banks and the region in which they are located are considered so as to explore the possible role of bank size and economic development in individual policies designed to address systemic risk; and

- The relationship between all major macroprudential policies and monetary policy and two proxies for systemic risk - increases in credit and house prices.

\section{A. Data and Methodology}

Panel fixed-effects models are used to examine the relationship between monetary and macroprudential policies and growth in loans and house prices, using annual data between 2000 and 2011. The fixed-effects panel regressions are run on available data in a sample of 171 banks and 31 provinces and municipalities during the same period.

To investigate whether the relationship between macroprudential and monetary policies and growth in loans and house prices depends on the size of the bank, the analysis is conducted separately for the five large banks and 166 small and medium-sized banks. In addition, to differentiate the possible different impact, we further divide the small and medium-sized banks into the joint stock commercial banks, city commercial banks, and foreign banks. In addition, these banks are also separated into three regional groups - east, middle, and west China. Since around two-thirds of large bank loans are provided to the east region, we place the five large banks in the east group (Figure 18). 
Figure 18. Shares of Loans to East China in Total Loans

(In percent, 2011)

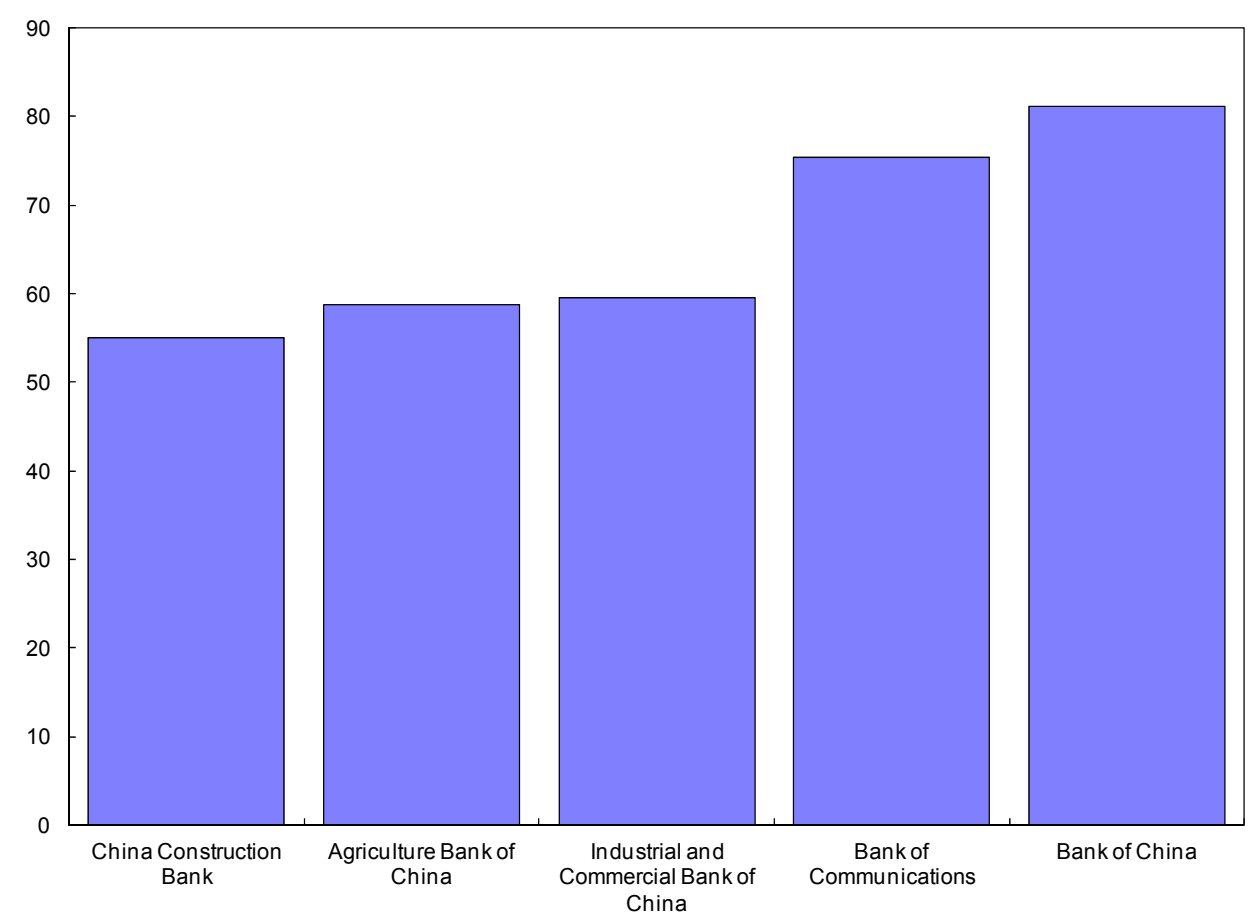

Source: Annual reports; authors' estimates.

To determine whether the relationship between macroprudential and monetary policies and growth in loans and house prices differs depending on the level of economic development, the analysis is also conducted separately for the east, middle, and west China. We take interest rates as a proxy for monetary policy; the RRR, house-related policies, capital ratio, liquidity ratio, reserves for impaired loans to total loans ratio as proxies for macroprudential policies; ${ }^{15}$ loan growth as an indicator of credit risk; and growth in house prices as an indicator of potential asset price bubbles. These variables are used in the context of the full sample and different regions (east, middle, and west), as well as for the subsamples of the five largest banks and 166 small and medium-sized banks. ${ }^{16}$ In addition, with time dimension

\footnotetext{
${ }^{15}$ Being a policy tool with the feature of both monetary policy and macorprudential policy, the RRR is taken as a major macroprudential policy tool in this paper. Federico and others (2012) shows that the RRR is widely employed as a macroprudential policy tool in emerging market economies. Being an emerging market economy, China has naturally deployed the RRR. Therefore, this paper takes the RRR as a major macroprudential policy tool. In addition, to exclude the possible effects of monetary policy, the empirical framework also incorporates the interest rate as an independent variable.

${ }^{16}$ In line with the practice in emerging economies, required reserve requirements have also become more complex and have been used to address a range of other policy objectives, not least macroeconomic management, financial stability and credit policy (Ma Guonan and others, 2011). A tightening of the RRR reduces the available funds or weakens demand for credit. This is particularly the case for small banks and small and medium-sized enterprises in China. Therefore, this paper takes the RRR mainly as a macroprudential policy in China.
} 
risk being China's main systemic risk, to explore the usefulness of those tools, the regressions also include the capital adequacy ratio (CAR), liquidity ratio, and the ratio of reserves for impaired loans to gross loans as macroprudential policy indicators.

Finally, given the short time since their adoption, some macroprudential policy tools, such as LTVs and capital surcharges, are not taken as independent variables in the paper. ${ }^{17}$ The dependent variables and independent (including "control") variables in the regressions are shown in Table 9.

\footnotetext{
${ }^{17}$ While some empirical studies find that LTVs have strong effects on house price appreciation rates (see IMF 2012b), the empirical analysis does not take LTVs as an independent variable for the following reasons: (i) the time series for LTVs is short; (ii) even for those years with available LTVs, this measure is constrained by the focus on very specific groups, making it difficult to determine the extent of its implementation. For instance, in March 2005, the LTV ratio was set at 70 percent for properties in cities or regions with very rapid house price increases and the decision whether to provide loans was up to the banks. In June 2006, the maximum LTV ratio was reduced from 80 percent to 70 percent for housing larger than $90 \mathrm{~m} 2$ excluding purchases for own use by individuals; in September 2007, the LTV was lowered to 60 percent only for second mortgages. In sum, the short-time coverage and sporadic application to specific segments make it hard to use the data for meaningful empirical results.
} 
Table 9. List of Variables Used in Regression Analysis

\begin{tabular}{|c|c|c|}
\hline \multicolumn{3}{|l|}{ List of dependent variables: } \\
\hline Concept & \begin{tabular}{|c|} 
Variable \\
\end{tabular} & Source \\
\hline Loan & Growth rate of loans in each bank & Bankscope \\
\hline House prices & $\begin{array}{l}\text { Growth rate of house prices in each city } \\
\text { where the banks are located }\end{array}$ & CEIC \\
\hline \multicolumn{3}{|c|}{ List of macroeconomic and institutional control variables: } \\
\hline Provincial GDP growth & $\begin{array}{l}\text { Growth rate of each province where the } \\
\text { banks are located }\end{array}$ & CEIC \\
\hline Provincial land supply & Growth rate of land supply area & China Land Almanac \\
\hline Inflation & Annual change in CPI & CEIC \\
\hline NDF & $\begin{array}{l}\text { Annual change in Non-Deliverable } \\
\text { Forward }\end{array}$ & Bloomberg \\
\hline Provincial real effective exchange rate & $\begin{array}{l}\text { Annual change in provincial real } \\
\text { exchange rate calculated based on } \\
\text { NEER and provincial CPI }\end{array}$ & $\begin{array}{l}\text { IMF, International Financial Statistics; } \\
\text { CEIC; authors' calculation. }\end{array}$ \\
\hline Foreign exchange reserve & $\begin{array}{l}\text { Annual change in foreign exchange } \\
\text { reserve }\end{array}$ & IMF, International Financial Statistics \\
\hline VIX & $\begin{array}{l}\text { Annual change in VIX (used as a } \\
\text { measure of global risk.) }\end{array}$ & Bloomberg \\
\hline \multicolumn{3}{|c|}{ List of monetary and macroprudential policy variables } \\
\hline Interest rate & Bank rate (End of period) & IMF, International Financial Statistics \\
\hline Required reserve ratio (RRR) & $\begin{array}{l}\text { Growth rate of each province where the } \\
\text { banks are located }\end{array}$ & CEIC \\
\hline House-related policies & $\begin{array}{l}\text { A dummy variable summarizing the } \\
\text { accumulated various house-related } \\
\text { policies by the state council and its } \\
\text { departments, excluding interest rate and } \\
\text { RRR policies. }\end{array}$ & The PBC, CBRC, and various sources. \\
\hline Capital ratio & $\begin{array}{l}\text { Capital Adequacy Ratio. It measures } \\
\text { Tier } 1+\text { Tier } 2 \text { capital which includes } \\
\text { subordinated debt, hybrid capital, loan } \\
\text { loss reserves and the valuation reserves } \\
\text { as a percentage of risk weighted assets } \\
\text { and off balance sheet risks. This ratio } \\
\text { should be at least } 8 \%\end{array}$ & Bankscope \\
\hline Liquidity ratio & $\begin{array}{l}\text { The ratio of liquid assets to total assets. } \\
\text { This is an indicator of a company's } \\
\text { solvency. }\end{array}$ & Bankscope \\
\hline $\begin{array}{l}\text { The ratio of reserves for impaired } \\
\text { loans/gross loans }\end{array}$ & $\begin{array}{l}\text { A reserve for losses expressed as a } \\
\text { percentage of total loans, indicating how } \\
\text { much of the total portfolio has been } \\
\text { provided for but not charged off. Given a } \\
\text { consistent charge-off policy, the higher } \\
\text { the ratio the poorer the quality of the } \\
\text { loan portfolio will be. liquidity asset ratio } \\
\text { is the ratio of liquidity assets to total } \\
\text { assets. }\end{array}$ & \begin{tabular}{|l|} 
Bankscope \\
\\
\end{tabular} \\
\hline Source: Authors. & & \\
\hline
\end{tabular}

Note: NDF is used to capture the RMB appreciation expectation. Provincial REER is not used to avoid endogeneity issue with $\mathrm{CPI}$ inflation, which is also used in the regression. 


\section{B. Estimation Strategy}

Two types of panel regression were run:

- $\quad$ The first type uses individual macroprudential policies and monetary policy to seek their separate association with growth rates in the loans of each bank and house prices in each province.

- $\quad$ The second type uses all macroprudential policies and monetary policy in a same panel specification

\section{Empirical Results}

\section{Variables for individual monetary and macroprudential policies}

This subsection summarizes the effects of individual monetary and macroprudential policies on the growth in loans and house prices. While mixed depending on the banks' sizes and locations, the results show that the RRR and house-related policies are useful in containing the excessive growth in house prices.

\section{(i) Results for individual policies in relation to loan growth (Tables 11 to 16 in} Annex II).

The results for individual policies show that the RRR, interest rates, the ratio of reserves for impaired loans to gross loans, the liquidity asset ratio, and the CAR are negatively associated with growth in loans in most cases, although the significance varies with different samples of size and location. Specifically:

- $\quad$ The change in the RRR is negatively associated with loan growth for large banks and banks in west China.

- Interest rates are negatively associated with loan growth in all samples, although it is insignificant for banks in middle and east China.

- $\quad$ House-related policies are ineffective in containing loan growth in all samples.

- $\quad$ A higher CAR is negatively associated with loan growth in the full sample, small and medium-sized banks, and banks in east China. However, it is insignificant in the large bank group, reflecting the fact that the loan growth in large banks is not sensitive to the capital buffer requirement.

- The liquidity ratio is insignificant in all samples, indicating its limited role in addressing loan growth. 
- The ratio of reserves for impaired loans to gross loans is negatively associated with loan growth in all samples, although positively associated with banks in west China. These results indicate that the ratio of reserves for impaired loans to gross loans is not effective in managing loan growth in the west region.

(ii) Results for individual policies in relation to house price growth (Tables 11 to 16 in Annex II).

The results show that, among all macroprudential policy measures, the RRR has the most significant negative association with house prices, although this is not the case for large banks and banks in middle and west China. Specifically:

- The change in the RRR is negatively associated with house price growth in all samples, except that it has a positive association for the large banks and banks in middle and west China, suggesting that a higher RRR for large banks and banks located in the west and middle regions is less associated with lower house prices.

- Interest rates are positively associated with house price growth in all sample groups, indicating a limited and unintended role for interest rates in managing house prices.

- $\quad$ House-related policies are negatively associated with house price growth in all samples, although it is insignificant for banks in middle and west China.

- $\quad$ Reserves for impaired loans are insignificantly associated with house price growth in all sample groups, indicating a limited association between the ratio of reserves for impaired loans to gross loans and house prices.

- A higher CAR is positively associated with house price growth in all samples, although it is insignificant for the banks in middle and west China. This may reflect the fact that banks with higher CARs tend to expand credit, thus contributing to the increases in house prices.

\section{Association with the multivariate policies}

This subsection summarizes the effects of multivariate policies on the growth in loans and house prices. The results further show that the RRR and house-related policies are useful in containing excessive house price growth.

(i) Results for multivariate policies in relation to loan growth (Table 18 in Annex II).

- $\quad$ All three policy tools - higher interest rates, higher RRR, and tougher housing policy - turn out to be insignificantly associated with lower loan growth except that higher interest rates are negatively associated with loan growth in the banks of the west. These suggest that, when the RRR and interest rate policy are implemented, the 
higher interest rate slows only the loan growth in the west region, though this region needs the most support.

(ii) Results for multivariate policies in relation to house price growth (Table 18 in Annex II).

- $\quad$ Higher interest rates are not associated with lower house prices in all samples.

- $\quad$ A higher RRR is associated with lower house prices in all cases except in large banks and banks in middle and west China. This is also consistent with the results in the regressions using the individual policies (Table 12).

- The house-related policy is effective in all samples, although it is ineffective for banks in middle and west China.

- In the group of small and medium-sized banks, the RRR is most negatively associated with foreign banks, with the coefficients for the joint-stock commercial banks and city commercial banks turning insignificant (Table 18). This indicates that the effectiveness of the RRR in containing house prices is highest for the foreign banks, followed by city commercial banks, joint-stock commercial banks, and lastly the large banks. In addition, house-related policy is effective across all subgroups of banks (Figure 19).

In sum, while the effects of the LTV ratio need to be tested with a longer time horizon, the RRR and house-related policies, among the macroprudential policy tools investigated, appear to be the most effective in cooling down house prices (except for large banks and the banks in middle and west China) (Table 10). 
Figure 19. Different House Price Impact of the RRR and House-related Policies on Different Types of Banks

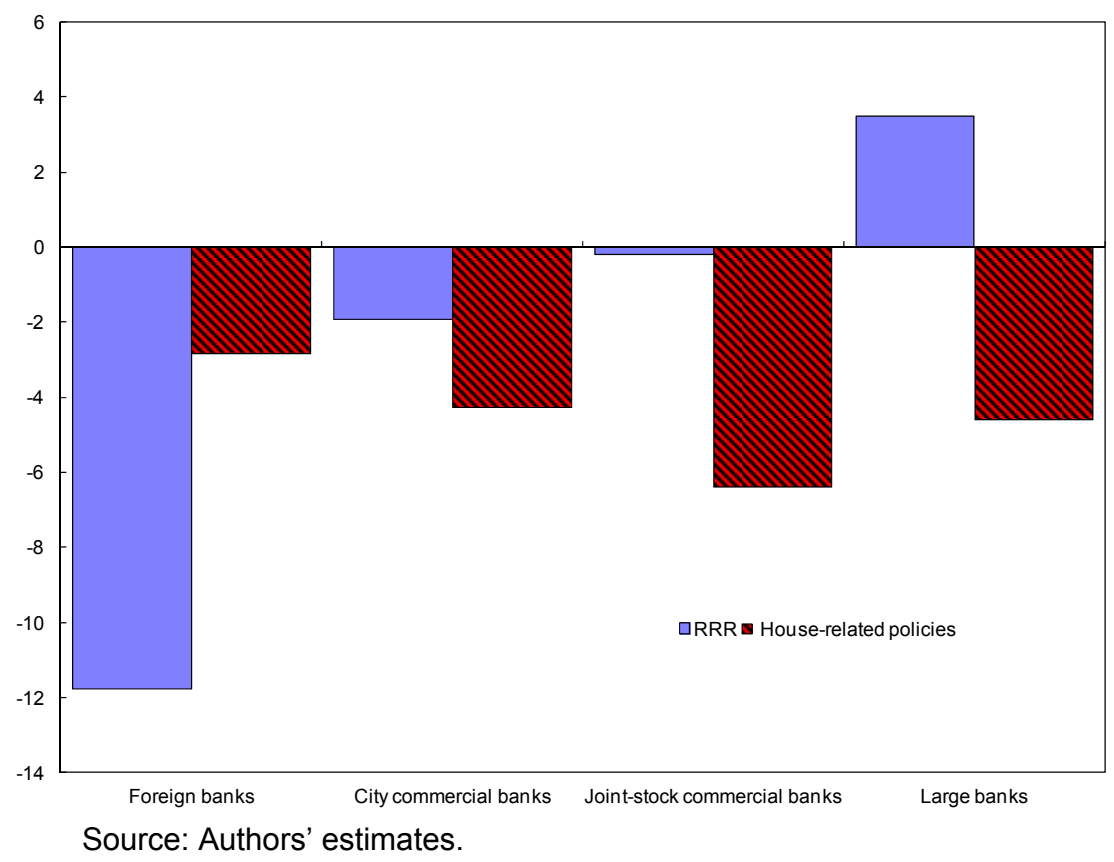

Note: The negative coefficients indicate that a tighter policy may be helpful for the banks to contain house price increases.

\section{Table 10. Summary of Fixed-Effects Panel Estimation Results}

\begin{tabular}{|c|c|c|c|c|c|c|}
\hline & \multicolumn{3}{|c|}{ Loan Growth } & \multicolumn{3}{|c|}{ House Price Growth } \\
\hline Variables & $\begin{array}{c}\text { Interest Rates } \\
\text { (Monetary } \\
\text { Policy) }\end{array}$ & $\begin{array}{c}\text { RRR (Macroprudential } \\
\text { Policy) }\end{array}$ & House Policies & $\begin{array}{c}\text { Interest Rates } \\
\text { (Monetary } \\
\text { Policy) }\end{array}$ & $\begin{array}{l}\text { RRR (Macroprudential } \\
\text { Policy) }\end{array}$ & House Policies \\
\hline \multicolumn{7}{|c|}{ Individual Policy with different samples of regions and sizes of banks } \\
\hline Full Sample & $-^{*}$ & - & + & $+t^{* \star *}$ & 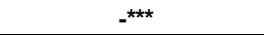 & 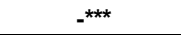 \\
\hline Large Banks & $--^{* *}$ & $--^{*}$ & $+^{*}$ & $+^{*}$ & + & $--^{\star \star}$ \\
\hline $\begin{array}{c}\text { Small/Medium } \\
\text { Banks }\end{array}$ & $-*$ & - & + & $t^{* *}$ & $-* *$ & 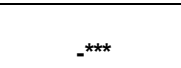 \\
\hline East & - & - & + & $+* * *$ & - -*** & $-* \star *$ \\
\hline Middle & - & - & $++^{* *}$ & + & + & - \\
\hline West & 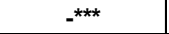 & $-{ }^{*}$ & - & + & - & - \\
\hline \multicolumn{7}{|c|}{ Interplay of the Policies } \\
\hline Full Sample & - & + & + & $+* * *$ & $-* \star *$ & $-\star \star \star *$ \\
\hline Large Banks & $--^{* *}$ & - & - & $t^{*}$ & + & $-* \star *$ \\
\hline $\begin{array}{c}\text { Small/Medium } \\
\text { Banks }\end{array}$ & - & + & + & $+* * *$ & 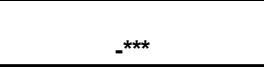 & $-* \star \star$ \\
\hline East & - & + & + & $t^{* * *}$ & 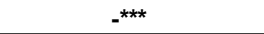 & 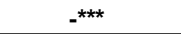 \\
\hline Middle & $t^{* *}$ & - & + & - & + & - \\
\hline West & $-* *$ & - & - & + & - & - \\
\hline
\end{tabular}

Source: Author's estimates.

Note: This table summarizes the results of the fixed-effects panel estimation on loans and house prices. + +/- indicate the sign of estimated coefficients. *** **, and * denote statistical significance at the 1 percent, 5 percent, and 10 percent levels of confidence based on robust standard errors. Coefficients that are statistically significant and have signs different than expected are in red. 
Results for the control variables further demonstrate the differences in the policy impact between the large and small banks, and between the banks in the east and the west. For instance:

- Differences exist between the large and the small and medium-sized banks in relation to economic growth in the provinces. For small and medium-sized banks, the growth rates in loans and house prices are positively associated with provincial growth, while these relationships turn negative for the large bank group. This further reflects the fact that small banks are more market-oriented than the large ones (Tables 12 and 13 in Annex II).

- $\quad$ The loans and house prices supported by the banks in the east are more positively associated with the expectation of RMB appreciation than banks in the middle and west, in line with the more export-oriented economy of the east region (Tables 14, 15, and 16 in Annex II). 


\section{Policy IMPLiCATions}

This section draws on the analysis above to offer tentative policy recommendations on improving the effectiveness of macroprudential policies in addressing systemic risk. The specific policy implications related to the policy tools are as follows:

- Systemic risk exists in China both in the time dimension and cross-sectional dimension. The former takes the form of excessive growth in credit and asset prices, and the latter is mainly reflected as the links between the banking sector and informal financing and local government financing platforms. The authorities have paid great attention and spared no efforts, including macroprudential policies, in containing the potential systemic risk.

- Macroprudential policies can be useful in containing the potential buildup of financial stress associated with the current economic and financial environment. Our results show that, in the current circumstances in China, when a lower interest rate policy spurs loan growth and gives rise to extremely strong incentives to take risk, the RRR and a house-related policy could be adopted to contain excessive increases in house prices. Macroprudential policies targeted at the excessive house price increases have the potential to contain the undesirable side effects of monetary policy on financial stability.

- The effectiveness of macroprudential policies is currently constrained. The current monetary policy framework and financial structure with ongoing unfinished reforms impose too great a burden on macroprudential policies to address financial stability concerns. In addition, imperfect macroprudential policies themselves are constrained by hard-to-capture financial stability concerns, limited and constrained policy tools, and institutional coordination challenges.

- Better-targeted macroprudential policies have greater potential to contain systemic risk. Both higher interest rates and tighter macroprudential policies are more associated with lowering loan growth in the banks in west China, even though the west needs more financial support. Therefore, policy could be differentiated between the banks in east/middle and west China, with less tough macroprudential policies being applied to banks in the west.

- Moreover, well-calibrated macroprudential policies can help ease the burden on monetary policy. The successful design and implementation of the macroprudential policy tools could help contain risks ex-ante, thereby easing the burden on monetary policy. In China, tightened macroprudential policies reduced the pressure on the authorities to raise interest rates, thus alleviating the dilemma between encouraging more capital inflows and hurting economic recovery when facing the global headwinds. 
- $\quad$ Further commercialization of the large banks would help improve the effectiveness of macroprudential policies. Our empirical results show that, the effectiveness of the RRR in containing house prices is highest for the foreign banks, followed by city commercial banks, joint-stock commercial banks, and lastly the large banks. In addition, while the loans by city commercial banks are positively associated with provincial GDP growth, this relationship turns negative for the large bank group. All the evidence indicates that improving policy transmission through the large banks is vital to fend off systemic risk. Therefore, further commercialization of the large banks should be on the policymakers' agenda.

- Broader reforms are vital to complement macroprudential policies to better contain systemic risk. Macroprudential policies should not be overburdened and need to be complemented by further financial, fiscal, and structural reforms. The ineffectiveness of an increase in land supply in slowing down house prices indicates that more attention should be paid to reducing the speculative demand for houses, for instance, by expanding financial investment channels and slowing down credit expansion. In particular, China is further liberalizing interest rates, exchange rates, and the capital account, which would greatly reduce the burden on macroprudential policies and enhance their effectiveness in containing the emergence of systemic risk due to financial distortions. Complemented by strong fiscal and structural policies, macroprudential policies can make an even stronger contribution.

- $\quad$ Further adjustments to the macroprudential policy toolkit are needed. With further liberalization going forward, it would be important to further adjust the macroprudential policy toolkit in China. More liberalized interest rates will focus on price and output stability, and macroprudential policies will focus on the sources of threats to financial stability. By establishing synergies, it will not only be possible for monetary and macroprudential policies to achieve both price stability and financial stability, but it will also greatly enhance welfare.

- $\quad$ Establishing an institutional framework is also required to attain the intended effects of macroprudential policies. It would be also vital to establish a supportive institutional framework to implement the macroprudential policies, which need to be well-coordinated among several agencies. There is no single or right set of institutional arrangements for promoting a macroprudential perspective of the financial system. Institutional arrangements need to have regard for country-specific circumstances, including the legal and political environment. One way of doing this in China would be to establish a permanent Financial Stability Committee, chaired by a very senior official with a clear mandate for monitoring systemic risk and making recommendations on the actions needed to address such risks (FSAP for China 
2011).$^{18}$ Membership of the Committee would need to include the authorities of the $\mathrm{PBC}$, the three supervisory agencies, the MOF, and any other relevant macroeconomic agencies. Such an outcome would be broadly consistent with the initiatives taken by many other G20 countries, as they seek to find ways to improve the resilience of their own financial systems and, by doing so, that of the global financial system. Finally, China needs to strengthen its data collection and improve coordination among its various institutions, along with the potential establishment of new institutions.

${ }^{18}$ See "People's Republic of China: Financial System Stability Assessment," IMF Country Report No. 11/321. 


\section{References}

Bank of England, 2011, "Instruments of Macroprudential Policies," Discussion Paper.

Borio, Claudio, 2009, "Implementing the Macroprudential Approach to Financial Regulation and Supervision," Banque de France Financial Stability Review, Vol. 13.

Denis BEAU, Laurent CLERC and Benoît MOJON, (2012)," Macro-Prudential Policy and the Conduct of Monetary Policy", http://www.benoitmojon.com/pdf/Beau-ClercMojon.pdf.

Federico, Pablo, Carlos A. Vegh, and Guillermo Vuletin, 2012, "Macroprudential policies over the Business Cycle," www.bde.es/webbde/gap/secciones/salaprensa/Vegh_Carlos.pdf.

FSB-IMF-BIS, 2011, "Macro-prudential Policy Tools and Frameworks," Progress Report to G-20.

Galati, Gabriele and Richhild Moessner, 2011, "Macro-prudential Policy—A Literature Review," BIS Workings Paper.

Gerlach, Stefan, Alberto Giovannini, Cédric Tille, and José Viñals, (2009), "Are the Golden Years of Central Banking Over? The Crisis and the Challenges," Geneva Reports on the World Economy 10.

Haibin Zhu, September 7, 2012, "PBC's Quantitative Measures: RRR and OMO," JPMorgan Chase Bank Economic Research Note.

International Monetary Fund, 2010, "Detecting Systemic Risk" Global Financial Stability Report. April 2010.

International Monetary Fund, 2011a, "Macroprudential policies: An Organizing Framework," IMF Policy Paper. March 2011.

International Monetary Fund, 2011b, Chapter 3, "Toward Operationalizing Macroprudential Policies: When to Act?” Global Financial Stability Report. September 2011.

International Monetary Fund and the Bank for International Settlements, and the Secretariat of the Financial Stability Board, "Guidance to Assess the Systemic Importance of Financial Institutions, Markets and Instruments: Initial Considerations" Report to the G-20 Finance Ministers and Central Bank Governors, October, 2009.

International Monetary Fund, 2012a,'The Interaction of Monetary and Macroprudential Policies", IMF Board Paper. 
International Monetary Fund, 2012b,'The Interaction of Monetary And Macroprudential Policies: Background Papers," IMF Board Paper.

Jordan, Thomas (2010)," The Interaction of Monetary and Macroprudential Policies”, Bank of Japan Conference "Future of Central Banking under Globalization", http://www.imes.boj.or.jp/english/publication/conf/2010/Panel_Jordan.pdf.

Lim, C, F. Columba, A. Costa, P. Kongsamut, A. Otani, M. Saiyid, T. Wezel, and X. Wu, 2011, "Macro-prudential Policy: What Instruments and How to Use Them? Lessons from Country Experiences," IMF Working Paper.

Lorenzo Bini Smaghi,(2011)," Macro-prudential Supervision and Monetary Policy Linkages and Demarcation Lines", Speech at the OeNB Annual Economic Conference on "The Future of European Integration: Some Economic Perspectives", http://www.ecb.int/press/key/date/2011/html/sp110523_1.en.html.

Lu, Yinqiu and Tao Sun, 2013, “Local Government Financing Platform: A Fortune or Misfortune?” IMF Working Paper (forthcoming).

Ma Guannan, Yan Xiangdong and Liu Xi, 2011, "China's Evolving Reserve Requirements," BOFIT Discussion Paper.

Marqués-Ibáñez D. and L. Gambacorta, (2011), “The Bank Lending Channel: Lessons from the Crisis", Economic Policy, 26, 66, 137-182.

Min, Liao, 2012, "The Framework to Monitor and Assess the Systemic Risk-China's Practice," www.imf.org/external/np/seminars/eng/2012/macroprudential.

Nier, Erlend W., Jacek Osiński, Luis I. Jácome, and Pamela Madrid, 2011a, "Institutional Models for Macro-prudential Policy," IMF Working Paper.

Ostry, Jonathan D., Atish R. Ghosh, Karl Habermeier, Luc Laeven, Marcos Chamon, Mahvash S. Qureshi, and Annamaria Kokenyne, 2011, "Managing Capital Inflows: What Tools to Use?" Discussion Paper.

Ouarda Merrouche and Erlend Nier, "What Caused the Global Financial Crisis? —Evidence on the Drivers of Financial Imbalances 1999-2007." IMF Working Paper.

Paolo Angelini \& Stefano Neri \& Fabio Panetta, (2012) "Monetary and Macroprudential Policies", Working Paper Series 1449, European Central Bank. 
Tovar, Camilo E., Mercedes Garcia-Escribano, and Mercedes Vera Marti, 2012, "Credit Growth and the Effectiveness of Reserve Requirements and Other Macroprudential Instruments in Latin America," IMF Working Paper 12/142.

Yasin Mimir, Enes Sunel and Temel Taskin, 2012, "Required Reserves as a Credit Policy Tool," MPRA Paper 39613, University Library of Munich, Germany. 


\section{Annex I. List of Sample Banks}

\section{Number}

\section{Bank Name}

Agricultural Bank of China Limited

\section{Region}

Allied Commercial Bank

East

Bangkok Bank (China) Co. Ltd.

East

Bank of Anshan Co. Ltd.

East

Bank of Beijing Co. Ltd.

East

Bank of Changsha Co. Ltd.

East

Middle

Bank of Chengdu Co. Ltd.

West

Bank of China Limited

East

Bank of Chongqing

West

Bank of Communications Co. Ltd.

East

Bank of Dalian

East

Bank of Deyang

West

Bank of Dongguan

East

Bank of East Asia (China) Ltd.

East

Bank of Fuxin Co. Ltd.

East

Bank of Guangzhou Co., Ltd.

East

Bank of Guilin Co. Ltd.

West

Bank of Hangzhou Co. Ltd.

East

Bank of Hebei Co. Ltd.

East

Bank of Inner Mongolia Co., Ltd.

Middle

Bank of Jiangsu Co. Ltd.

East

Bank of Jilin Co. Ltd.

Middle

Bank of Jinhua Co. Ltd.

East

Bank of Jining Co. Ltd.

East

Bank of Jinzhou Co. Ltd.

East

Bank of Jiujiang Co. Ltd.

West

Bank of Kunlun Co. Ltd.

West

Bank of Liaoyang Co. Ltd.

East

Bank of Liuzhou Co. Ltd.

West

Bank of Luoyang Co. Ltd.

Middle

Bank of Montreal (China) Co. Ltd.

East

Bank of Nanchang Co., Ltd.

Middle

Bank of Nanjing

East

Bank of Ningbo

East

Bank of Ningxia Co. Ltd.

West

Bank of Qingdao Co. Ltd.

East

Bank of Rizhao

East

Bank of Shanghai

East

Bank of Shaoxing Co. Ltd. 


\begin{tabular}{|c|c|c|}
\hline Number & Bank Name & Region \\
\hline 40 & Bank of Suzhou Co. Ltd. & East \\
\hline 41 & Bank of Tianjin & East \\
\hline 42 & Bank of Tokyo Mitsubishi UFJ (China) Ltd. & East \\
\hline 43 & Bank of Weifang Co. Ltd. & East \\
\hline 44 & Bank of Wenzhou Co. Ltd. & East \\
\hline 45 & Bank of Xinxiang Co. Ltd. & Middle \\
\hline 46 & Bank of Yingkou & East \\
\hline 47 & Baoshang Bank & East \\
\hline 48 & Beijing Rural Commercial Bank Co. Ltd. & East \\
\hline 49 & BNP Paribas (China) & East \\
\hline 50 & Cangzhou City Commercial Bank & East \\
\hline 51 & Changshu Rural Commercial Bank & East \\
\hline 52 & Changzhi City Commercial Bank & Middle \\
\hline 53 & Chengde City Commercial Bank Co. Ltd. & East \\
\hline 54 & China \& South Sea Bank Ltd., (The) & East \\
\hline 55 & China Bohai Bank & East \\
\hline 56 & China CITIC Bank Corporation Limited & East \\
\hline 57 & China Construction Bank Corporation & East \\
\hline 58 & China Development Bank Corporation & East \\
\hline 59 & China Everbright Bank Co. Ltd. & East \\
\hline 60 & China Guangfa Bank Co. Ltd. & East \\
\hline 61 & China Merchants Bank Co. Ltd. & East \\
\hline 62 & China Minsheng Banking Corporation & East \\
\hline 63 & China Resources Bank of Zhuhai Co. Ltd. & East \\
\hline 64 & China State Bank Ltd. & East \\
\hline 65 & China Zheshang Bank Co. Ltd. & East \\
\hline 66 & Chinese Mercantile Bank & East \\
\hline 67 & Chongqing Rural Commercial Bank & West \\
\hline 68 & Citibank (China) Co. Ltd. & East \\
\hline 69 & CITIC Bank International (China) Limited & East \\
\hline 70 & Commercial Bank of Zhengzhou & Middle \\
\hline 71 & Credit Agricole CIB (China) & East \\
\hline 72 & Dah Sing Bank, Ltd. & East \\
\hline 73 & Datong City Commercial Bank & Middle \\
\hline 74 & DBS BANK (China) Limited & East \\
\hline 75 & Deutsche Bank (China) Co. Ltd. & East \\
\hline 76 & Dezhou Bank Co. Ltd. & East \\
\hline 77 & Dongguan Rural Commercial Bank Co. Ltd. & East \\
\hline 78 & Dongying Bank Co. Limited & East \\
\hline 79 & East West Bank (China) Limited & East \\
\hline
\end{tabular}




\begin{tabular}{|c|c|c|}
\hline Number & Bank Name & Region \\
\hline 80 & Evergrowing Bank Co. Ltd. & East \\
\hline 81 & First Sino Bank & East \\
\hline 82 & Foshan Shunde Rural Commercial Bank Company Limited & East \\
\hline 83 & Fudian Bank Co. Ltd. & West \\
\hline 84 & Fujian Haixia Bank Co. Ltd. & East \\
\hline 85 & Ganzhou City Commercial Bank & Middle \\
\hline 86 & Guangdong Huaxing Bank Co. Ltd. & East \\
\hline 87 & Guangxi Beibu Gulf Bank Co. Ltd. & West \\
\hline 88 & Guangzhou Rural Commercial Bank Co., Ltd. & East \\
\hline 89 & Guiyang Commercial Bank Co. Ltd. & West \\
\hline 90 & Hana Bank (China) Company Ltd. & East \\
\hline 91 & Handan Commercial Bank Co Ltd. & East \\
\hline 92 & Hang Seng Bank (China) Limited & East \\
\hline 93 & Hankou Bank & Middle \\
\hline 94 & Harbin Bank & Middle \\
\hline 95 & Hengyang City Commercial Bank & Middle \\
\hline 96 & HSBC Bank (China) Co. Ltd. & East \\
\hline 97 & Hua Xia Bank Co., Limited & East \\
\hline 98 & Huangshi City Commercial Bank & Middle \\
\hline 99 & Huishang Bank Co. Ltd. & Middle \\
\hline 100 & Huzhou City Commercial Bank & East \\
\hline 101 & Industrial \& Commercial Bank of China (The) - ICBC & East \\
\hline 102 & Industrial Bank Co. Ltd. & East \\
\hline 103 & Industrial Bank of Korea (China) Limited & East \\
\hline 104 & Jiangsu Jiangyin Rural Commercial Bank & East \\
\hline 105 & Jiangsu Wujiang Rural Commercial Bank & East \\
\hline 106 & Jiangsu Zhangjiagang Rural Commercial Bank Co. Ltd. & East \\
\hline 107 & Jiaozuo City Commercial Bank Co. Ltd. & Middle \\
\hline 108 & Jiaxing City Commercial Bank Co. Ltd. & East \\
\hline 109 & Jingzhou City Commercial Bank Co. Ltd. & Middle \\
\hline 110 & Jiujiang City Commercial Bank Co. Ltd. & Middle \\
\hline 111 & JP Morgan Chase Bank (China) Co. Ltd. & East \\
\hline 112 & Karamay City Commercial Bank Co. Ltd. & East \\
\hline 113 & KEB Bank (China) Co., Ltd. & East \\
\hline 114 & Kincheng Banking Corporation & East \\
\hline 115 & Kunshan Rural Commercial Bank & East \\
\hline 116 & Kwangtung Provincial Bank (The) & East \\
\hline 117 & Laishang Bank Co. Ltd. & East \\
\hline 118 & Lanzhou City Commercial Bank Co. Ltd. & West \\
\hline 119 & Linshang Bank Co. Ltd. & East \\
\hline
\end{tabular}




\begin{tabular}{|c|c|c|}
\hline Number & Bank Name & Region \\
\hline 120 & Metropolitan Bank (China) Ltd. & East \\
\hline 121 & Mianyang City Commercial Bank & West \\
\hline 122 & Mizuho Corporate Bank China Ltd. & East \\
\hline 123 & Nanchong City Commercial Bank Co., Ltd. & East \\
\hline 124 & Nanhai Rural Credit Union & East \\
\hline 125 & Nanning City Commercial Bank & West \\
\hline 126 & Nantong City Commercial Bank Co. Ltd. & East \\
\hline 127 & Nanyang Commercial Bank (China) Limited & Middle \\
\hline 128 & National Commercial Bank Ltd. & East \\
\hline 129 & Ningbo Commercial Bank Corporation Ltd. & East \\
\hline 130 & OCBC Bank (China) Limited & East \\
\hline 131 & Ordos Commercial Bank & Middle \\
\hline 132 & Panzhihua City Commercial Bank Co. Ltd. & West \\
\hline 133 & Ping An Bank & East \\
\hline 134 & Ping An Bank Co. Ltd. & East \\
\hline 135 & Ping An Bank Co. Ltd. & East \\
\hline 136 & Qilu Bank Co Ltd. & East \\
\hline 137 & Qingdao International Bank & East \\
\hline 138 & Qishang Bank. & East \\
\hline 139 & Royal Bank of Scotland (China) Co. Ltd. (The) & East \\
\hline 140 & Shanghai Pudong Development Bank & East \\
\hline 141 & Shanghai Rural Commercial Bank & East \\
\hline 142 & Shangrao City Commercial Bank & Middle \\
\hline 143 & Shengjing Bank & East \\
\hline 144 & Shenzhen Rural Commercial Bank Co. Ltd. & East \\
\hline 145 & Shinhan Bank (China) Limited & East \\
\hline 146 & Sin Hua Bank Limited & East \\
\hline 147 & Societe Generale (China) Limited & East \\
\hline 148 & Standard Chartered Bank (China) Ltd. & East \\
\hline 149 & Sumitomo Mitsui Banking Corporation (China) Limited & East \\
\hline 150 & Suzhou City Commercial Bank Co. Ltd. & East \\
\hline 151 & Taizhou City Commercial Bank & East \\
\hline 152 & United Overseas Bank (China) Limited & East \\
\hline 153 & Weihai City Commercial Bank Co. Ltd. & East \\
\hline 154 & Wing Hang Bank (China) Ltd. & East \\
\hline 155 & Woori Bank (China) Ltd. & East \\
\hline 156 & Wuxi City Commercial Bank & East \\
\hline 157 & Xi'an City Commercial Bank & West \\
\hline 158 & Xiamen Bank & East \\
\hline 159 & Xiamen International Bank & East \\
\hline
\end{tabular}


Number

160

161

162

163

164

165

166

167

168

169

170

171
Bank Name

Xiaogan City Commercial Bank Co. Ltd.

Xinyang City Commercial Bank Co. Ltd.

Xuchang City Commercial Bank Co. Ltd.

Yangzhou City Commercial Bank Ltd.

Yantai Bank Co. Ltd.

Yien Yieh Commercial Bank Ltd.

Zhanjiang City Commercial Bank Co. Ltd.

Zhejiang Chouzhou Commercial Bank

Zhejiang Mintai Commercial Bank

Zhejiang Tailong Commercial Bank Co. Ltd.

Zhengxin Bank Company Limited

Zhenjiang City Commercial Bank
Region

Middle

Middle

Middle

East

East

East

East

East

East

East

East

East 
Annex II. Detailed Panel Estimation Results

Table 11. Results of Individual Variables Based on the Full Sample

\begin{tabular}{|c|c|c|c|c|c|c|c|c|c|c|c|c|}
\hline & Loans & House Price & Loans & House Price & Loans & House Price & Loans & House Price & Loans & House Price & Loans & House Price \\
\hline \multicolumn{13}{|l|}{ Control variables } \\
\hline \multirow[t]{2}{*}{ Provincial GDP growth } & 0.168 & $0.588^{\star \star}$ & 0.304 & 0.463 & 0.220 & 0.361 & 0.361 & $0.695^{\star \star}$ & 0.059 & $0.830^{\star \star *}$ & 0.531 & $0.870^{\star \star}$ \\
\hline & $(0.292)$ & $(2.042)$ & $(0.543)$ & (1.495) & $(0.416)$ & (1.145) & $(0.833)$ & $(1.990)$ & $(0.113)$ & $(2.820)$ & $(1.045)$ & $(2.483)$ \\
\hline \multirow[t]{2}{*}{ Inflation (CPI) } & 0.338 & $2.890^{\star \star *}$ & 0.197 & $1.700^{\star \star *}$ & 1.484 & -0.665 & -1.457 & $0.975^{*}$ & 0.212 & 0.545 & $-2.015^{\star *}$ & 0.535 \\
\hline & $(0.187)$ & $(8.449)$ & $(0.161)$ & (3.670) & $(0.947)$ & $(-0.928)$ & $(-1.615)$ & $(1.695)$ & $(0.163)$ & $(1.251)$ & $(-2.169)$ & $(1.140)$ \\
\hline \multirow[t]{2}{*}{ Foreign reserve growth } & -0.088 & -0.088 & 0.029 & -0.236 & -0.292 & 0.118 & -0.317 & -0.005 & -0.187 & -0.040 & -0.042 & -0.078 \\
\hline & $(-0.478)$ & $(-0.464)$ & $(0.150)$ & $(-1.246)$ & $(-1.246)$ & $(0.593)$ & $(-1.472)$ & $(-0.044)$ & $(-0.938)$ & $(-0.429)$ & $(-0.287)$ & $(-0.730)$ \\
\hline \multirow[t]{2}{*}{$\overline{N D F(H K)}$} & -1.911 & $-2.857^{\star \star \star}$ & $-1.415^{\star \star}$ & $-0.841^{* \star *}$ & $-1.914^{\star \star \star}$ & 0.232 & $-0.721^{*}$ & $-0.725^{\star \star \star}$ & $-1.098^{\star \star}$ & $-0.928^{\star \star \star}$ & -0.286 & $-0.913^{* * \star}$ \\
\hline & $(-1.037)$ & $(-3.609)$ & $(-2.470)$ & $(-3.710)$ & $(-2.600)$ & $(1.272)$ & $(-1.815)$ & $(-2.621)$ & $(-2.036)$ & $(-4.523)$ & $(-1.243)$ & $(-4.367)$ \\
\hline \multirow[t]{2}{*}{$\overline{V I X I n d e x}$} & -0.019 & $-0.537^{\star \star *}$ & -0.277 & $-0.503^{* * \star}$ & -0.011 & $-0.646^{* \star *}$ & 0.186 & $-0.573^{\star \star *}$ & -0.080 & $-0.448^{\star \star \star}$ & -0.085 & $-0.503^{* * *}$ \\
\hline & $(-0.086)$ & $(-2.847)$ & $(-1.307)$ & $(-3.193)$ & $(-0.051)$ & $(-3.828)$ & $(1.028)$ & $(-3.293)$ & $(-0.321)$ & $(-3.407)$ & $(-0.459)$ & $(-3.369)$ \\
\hline \multirow[t]{2}{*}{ Land supply area } & -0.036 & $0.076^{* \star}$ & -0.040 & $0.084^{\star \star \star}$ & -0.031 & $0.067^{\star \star}$ & 0.008 & $0.064^{\star \star \star}$ & -0.030 & $0.069^{\star \star \star}$ & -0.033 & $0.060^{\star \star \star}$ \\
\hline & $(-1.375)$ & $(2.327)$ & $(-1.513)$ & (2.592) & $(-1.243)$ & $(2.080)$ & $(0.334)$ & $(2.794)$ & $(-1.158)$ & $(3.456)$ & $(-1.264)$ & (3.029) \\
\hline \multirow[t]{2}{*}{ Loan with one lag } & -0.053 & & -0.056 & & -0.054 & & -0.018 & & -0.062 & & -0.123 & \\
\hline & $(-0.769)$ & & $(-0.811)$ & & $(-0.775)$ & & $(-0.348)$ & & $(-0.900)$ & & $(-1.108)$ & \\
\hline \multirow[t]{2}{*}{ Provincial house price with one lag } & & -0.027 & & $-0.056^{\star \star}$ & & $-0.123^{\star \star \star}$ & & $-0.160^{* \star *}$ & & $-0.173^{* \star *}$ & & $-0.122^{\star \star \star}$ \\
\hline & & $(-0.916)$ & & $(-2.035)$ & & $(-3.549)$ & & $(-3.241)$ & & $(-4.369)$ & & $(-2.865)$ \\
\hline \multicolumn{13}{|l|}{ Policy variables } \\
\hline Reserve requirement ratio & -1.502 & $-3.362^{* \star *}$ & & & & & & & & & & \\
\hline (Macroprudential policy) & $(-0.468)$ & $(-2.751)$ & & & & & & & & & & \\
\hline Bank rate (EOP) & & & $-14.296^{*}$ & $7.078^{\star \star \star}$ & & & & & & & & \\
\hline (Monetary policy) & & & $(-1.820)$ & $(2.857)$ & & & & & & & & \\
\hline House-related policy dummy & & & & & 3.438 & $-4.693^{* \star *}$ & & & & & & \\
\hline (House-related policy) & & & & & $(1.323)$ & $(-7.703)$ & & & & & & \\
\hline Capital adequacy ratio & & & & & & & $-0.402^{\star \star \star}$ & $0.112^{\star \star \star *}$ & & & & \\
\hline (Macroprudential policy) & & & & & & & $(-4.942)$ & $(3.810)$ & & & & \\
\hline Liquidity ratio & & & & & & & & & -0.275 & $0.139^{*}$ & & \\
\hline (Macroprudential policy) & & & & & & & & & $(-1.199)$ & $(1.684)$ & & \\
\hline Reserves for Impaired Loans/ Gross loans & & & & & & & & & & & $-4.286^{* \star *}$ & -0.352 \\
\hline (Macroprudential policy) & & & & & & & & & & & $(-3.461)$ & $(-0.701)$ \\
\hline \multicolumn{13}{|l|}{ Constant } \\
\hline Constant & $25.416^{*}$ & -3.437 & $64.220^{* \star *}$ & $-13.526^{*}$ & $38.676^{* \star \star}$ & $-6.647^{\star \star *}$ & $38.400^{* \star \star}$ & 0.503 & $38.143^{* \star *}$ & -1.931 & $37.328^{* * *}$ & 2.153 \\
\hline Number of banks & 118.000 & 171.000 & 118.000 & 171.000 & 118.000 & 171.000 & 103.000 & 147.000 & 118.000 & 158.000 & 113.000 & 157.000 \\
\hline Number of observations & 485 & 1,437 & 485 & 1,437 & 485 & 1,437 & 372 & 534 & 484 & 710 & 441 & 649 \\
\hline R-squared (overall) & 0.000 & 0.054 & 0.000 & 0.054 & 0.000 & 0.067 & 0.011 & 0.098 & 0.006 & 0.125 & 0.049 & 0.115 \\
\hline
\end{tabular}

Source: IMF staff estimates.

Note: The table presents panel fixed-effects regressions on policies and factors affecting credit (Loan) and house price in China between 2000 and 2011 . Standard errors are shown under the coefficients. ${ }^{* * *},{ }^{* *}$, and * denote statistical significance at the 1 percent, 5 percent, and 10 percent levels of confidence based on robust standard errors. For the definition of dependent variables and independent variables, see table 6 , respectively. For sample banks, see annex I. 
Table 12. Results of Individual Variables Based on the Sample of Large Banks

\begin{tabular}{|c|c|c|c|c|c|c|c|c|c|c|c|c|}
\hline & Loans & House Price & Loans & House Price & Loans & House Price & Loans & House Price & Loans & House Price & Loans & House Price \\
\hline \multicolumn{13}{|l|}{ Control variables } \\
\hline \multirow[t]{2}{*}{$\begin{array}{l}\text { Provincial GDP growth } \\
\text {. }\end{array}$} & $-2.387^{*}$ & $-2.101^{\star \star \star}$ & 0.731 & $-1.972^{\star \star \star}$ & $-2.451^{*}$ & -0.950 & $-1.865^{*}$ & $-0.605^{\star \star \star}$ & -1.405 & $-2.114^{\star \star \star}$ & $-2.083^{\star \star}$ & $-1.156^{\star \star}$ \\
\hline & $(-1.936)$ & $(-10.821)$ & (1.461) & $(-78.646)$ & $(-1.933)$ & $(-1.111)$ & $(-1.695)$ & $(-3.385)$ & $(-0.892)$ & $(-2.656)$ & $(-2.455)$ & $(-2.310)$ \\
\hline \multirow[t]{2}{*}{ Inflation (CPI) } & $10.233^{*}$ & 0.868 & -0.496 & $2.211^{\star \star \star}$ & 4.778 & -0.429 & 1.260 & 0.802 & 0.102 & $3.586^{\star \star \star}$ & $2.271^{*}$ & $2.150^{\star \star}$ \\
\hline & $(1.760)$ & $(0.239)$ & $(-0.340)$ & (12.947) & $(1.476)$ & $(-0.376)$ & $(0.882)$ & $(1.112)$ & $(0.056)$ & $(3.052)$ & $(1.687)$ & (2.359) \\
\hline \multirow[t]{2}{*}{ Foreign reserve growth } & $-0.393^{*}$ & $0.741^{\star \star}$ & -0.182 & $0.385^{\star \star \star}$ & $-0.333^{*}$ & $0.658^{\star \star \star}$ & -0.140 & $0.517^{\star \star \star}$ & -0.052 & $0.497^{\star \star \star}$ & $-0.191^{\star}$ & $0.552^{\star \star \star}$ \\
\hline & $(-1.869)$ & $(2.292)$ & $(-0.988)$ & $(10.381)$ & $(-1.668)$ & (16.471) & $(-0.663)$ & $(3.540)$ & $(-0.415)$ & $(3.821)$ & $(-1.656)$ & (28.603) \\
\hline \multirow{2}{*}{ NDF (HK) } & $-6.634^{* \star}$ & -1.789 & $-1.042^{\star \star \star}$ & $-2.712^{\star \star \star}$ & $-3.238^{* \star}$ & $-1.356^{*}$ & $-1.438^{*}$ & $-1.896^{\star \star \star}$ & -1.138 & $-3.246^{\star \star \star}$ & $-1.434^{\star *}$ & $-2.953^{* \star \star}$ \\
\hline & $(-2.006)$ & $(-0.694)$ & $(-2.918)$ & $(-57.049)$ & $(-2.020)$ & $(-1.892)$ & $(-1.758)$ & $(-4.483)$ & $(-1.376)$ & $(-11.685)$ & $(-2.459)$ & $(-7.313)$ \\
\hline \multirow[t]{2}{*}{ VIXIndex } & -0.454 & $-0.741^{\star * *}$ & -0.444 & $-0.394^{\star \star \star}$ & -0.161 & $-0.458^{\star \star \star}$ & -0.039 & $-0.655^{\star \star \star}$ & -0.027 & $-0.745^{\star \star \star}$ & -0.121 & $-0.579^{\star \star \star}$ \\
\hline & $(-1.093)$ & $(-3.037)$ & $(-1.255)$ & $(-4.116)$ & $(-0.506)$ & $(-4.185)$ & $(-0.133)$ & $(-5.827)$ & $(-0.100)$ & $(-4.368)$ & $(-0.769)$ & $(-2.609)$ \\
\hline \multirow[t]{2}{*}{ Land supply area } & $0.055^{*}$ & -0.035 & 0.038 & 0.008 & $0.055^{*}$ & -0.026 & $0.086^{\star *}$ & 0.041 & $0.088^{\star \star}$ & -0.003 & $0.076^{\star \star}$ & 0.027 \\
\hline & (1.862) & $(-0.520)$ & $(1.282)$ & $(0.250)$ & $(1.881)$ & $(-0.333)$ & $(2.291)$ & $(0.440)$ & (2.293) & $(-0.020)$ & (2.352) & $(0.203)$ \\
\hline \multirow[t]{2}{*}{ Loan with one lag } & 0.015 & & -0.054 & & 0.016 & & 0.001 & & 0.007 & & -0.230 & \\
\hline & $(0.099)$ & & $(-0.363)$ & & $(0.109)$ & & $(0.011)$ & & $(0.034)$ & & $(-1.111)$ & \\
\hline \multirow{2}{*}{ Provincial house price with one lag } & & 0.233 & & 0.184 & & $0.042^{\star \star \star}$ & & 0.081 & & 0.214 & & 0.199 \\
\hline & & (1.504) & & $(1.504)$ & & (3.113) & & $(0.600)$ & & $(0.885)$ & & $(0.946)$ \\
\hline \multicolumn{13}{|l|}{ Policy variables } \\
\hline Reserve requirement ratio & $-11.568^{*}$ & 3.498 & & & & & & & & & & \\
\hline (Macroprudential policy) & $(-1.959)$ & $(0.496)$ & & & & & & & & & & \\
\hline Bank rate (EOP) & & & $-41.346^{\star \star}$ & $19.172^{*}$ & & & & & & & & \\
\hline (Monetary policy) & & & $(-2.068)$ & $(1.843)$ & & & & & & & & \\
\hline House-related policy dummy & & & & & $7.083^{*}$ & $-5.162^{\star \star}$ & & & & & & \\
\hline (House-related policy) & & & & & $(1.957)$ & $(-2.016)$ & & & & & & \\
\hline Capital adequacy ratio & & & & & & & -1.032 & $2.893^{* \star *}$ & & & & \\
\hline (Macroprudential policy) & & & & & & & $(-0.512)$ & $(10.368)$ & & & & \\
\hline Liquidity ratio & & & & & & & & & 0.402 & -0.431 & & \\
\hline (Macroprudential policy) & & & & & & & & & $(0.450)$ & $(-0.522)$ & & \\
\hline Reserves for Impaired Loans/ Gross loans & & & & & & & & & & & $-11.988^{\star \star \star}$ & -0.668 \\
\hline (Macroprudential policy) & & & & & & & & & & & $(-4.425)$ & $(-1.012)$ \\
\hline \multicolumn{13}{|l|}{ Constant } \\
\hline Constant & $38.093^{\star \star \star}$ & $10.978^{\star \star \star}$ & $141.721^{\star \star}$ & -39.255 & $70.683^{\star \star \star}$ & -9.427 & $55.627^{*}$ & $-30.004^{\star \star \star}$ & 29.610 & 21.427 & $79.923^{\star \star \star}$ & 4.586 \\
\hline Number of banks & 5.000 & 5.000 & 5.000 & 5.000 & 5.000 & 5.000 & 5.000 & 5.000 & 5.000 & 5.000 & 5.000 & 5.000 \\
\hline Number of observations & 28 & 50 & 28 & 50 & 28 & 50 & 28 & 36 & 28 & 38 & 28 & 38 \\
\hline R-squared (overall) & 0.730 & 0.506 & 0.628 & 0.548 & 0.730 & 0.556 & 0.639 & 0.436 & 0.654 & 0.380 & 0.594 & 0.394 \\
\hline
\end{tabular}

Source: IMF staff estimates.

Note: The table presents panel fixed-effects regressions on policies and factors affecting credit (Loan) and house price in China between 2000 and 2011. Standard errors are shown under the coefficients. ${ }^{* * *},{ }^{* *}$, and ${ }^{*}$ denote statistical significance at the 1 percent, 5 percent, and 10 percent levels of confidence based on robust standard errors. For the definition of dependent variables and independent variables, see table 6 , respectively. For sample banks, see annex I. 
Table 13. Results of Individual Variables Based on the Sample of Small- and Medium-Sized Banks

\begin{tabular}{|c|c|c|c|c|c|c|c|c|c|c|c|c|}
\hline & Loans & House Price & Loans & House Price & Loans & House Price & Loans & House Price & Loans & House Price & Loans & House Price \\
\hline \multicolumn{13}{|l|}{ Control variables } \\
\hline \multirow[t]{2}{*}{ Provincial GDP growth } & 0.314 & $0.677^{\star \star}$ & 0.380 & $0.522^{*}$ & 0.335 & 0.400 & 0.483 & $0.818^{\star \star}$ & 0.164 & $0.919^{\star \star \star}$ & 0.653 & $0.928^{\star \star}$ \\
\hline & $(0.485)$ & $(2.453)$ & $(0.658)$ & $(1.681)$ & $(0.610)$ & $(1.250)$ & $(1.027)$ & $(2.217)$ & $(0.305)$ & $(3.003)$ & (1.219) & (2.524) \\
\hline \multirow[t]{2}{*}{ Inflation (CPI) } & 0.463 & $2.958^{\star \star \star}$ & 0.068 & $1.676^{\star \star \star}$ & 1.392 & -0.594 & $-1.643^{*}$ & 0.860 & 0.115 & 0.478 & $-2.364^{\star *}$ & 0.467 \\
\hline & $(0.231)$ & $(8.839)$ & $(0.051)$ & (3.314) & $(0.832)$ & $(-0.772)$ & $(-1.679)$ & (1.315) & $(0.083)$ & $(1.004)$ & $(-2.412)$ & $(0.883)$ \\
\hline \multirow[t]{2}{*}{ Foreign reserve growth } & -0.030 & -0.092 & 0.066 & -0.246 & -0.255 & 0.093 & -0.287 & -0.019 & -0.151 & -0.057 & 0.034 & -0.084 \\
\hline & $(-0.139)$ & $(-0.453)$ & $(0.309)$ & $(-1.264)$ & $(-1.006)$ & $(0.451)$ & $(-1.149)$ & $(-0.155)$ & $(-0.693)$ & $(-0.579)$ & $(0.205)$ & $(-0.756)$ \\
\hline \multirow[t]{2}{*}{ NDF (HK) } & -2.437 & $-3.122^{* \star \star}$ & $-1.441^{* \star}$ & $-0.812^{\star \star \star}$ & $-1.963^{* \star}$ & 0.232 & $-0.742^{*}$ & $-0.630^{* *}$ & $-1.138^{* *}$ & $-0.849^{* \star \star}$ & -0.273 & $-0.851^{\star \star \star}$ \\
\hline & $(-0.962)$ & $(-3.215)$ & $(-2.329)$ & $(-3.569)$ & $(-2.509)$ & (1.257) & $(-1.649)$ & $(-2.175)$ & $(-1.963)$ & $(-3.976)$ & $(-1.095)$ & $(-3.937)$ \\
\hline \multirow[t]{2}{*}{ VIX Index } & -0.010 & $-0.526^{\star \star \star}$ & -0.267 & $-0.518^{\star \star \star}$ & -0.012 & $-0.654^{\star \star \star}$ & 0.185 & $-0.597^{\star \star \star}$ & -0.087 & $-0.473^{* \star *}$ & -0.113 & $-0.542^{\star \star \star}$ \\
\hline & $(-0.043)$ & $(-2.586)$ & $(-1.182)$ & $(-3.129)$ & $(-0.050)$ & $(-3.731)$ & $(0.925)$ & $(-3.137)$ & $(-0.328)$ & $(-3.358)$ & $(-0.578)$ & $(-3.389)$ \\
\hline \multirow[t]{2}{*}{ Land supply area } & -0.039 & $0.077^{\star \star}$ & -0.041 & $0.085^{\star \star}$ & -0.031 & $0.070^{\star \star}$ & 0.006 & $0.068^{\star \star \star}$ & -0.031 & $0.071^{\star \star *}$ & -0.039 & $0.061^{\star \star \star}$ \\
\hline & $(-1.350)$ & $(2.240)$ & $(-1.424)$ & $(2.553)$ & $(-1.148)$ & $(2.063)$ & $(0.250)$ & $(2.782)$ & $(-1.095)$ & (3.431) & $(-1.343)$ & $(2.957)$ \\
\hline \multirow[t]{2}{*}{ Loan with one lag } & -0.056 & & -0.058 & & -0.056 & & -0.023 & & -0.064 & & -0.132 & \\
\hline & $(-0.797)$ & & $(-0.829)$ & & $(-0.801)$ & & $(-0.445)$ & & $(-0.926)$ & & $(-1.173)$ & \\
\hline \multirow[t]{2}{*}{ Provincial house price with one lag } & & -0.040 & & $-0.066^{\star \star}$ & & $-0.129^{\star \star \star}$ & & $-0.190^{\star \star \star}$ & & $-0.197^{\star \star \star}$ & & $-0.140^{\star \star \star}$ \\
\hline & & $(-1.333)$ & & $(-2.362)$ & & $(-3.608)$ & & $(-3.514)$ & & $(-4.683)$ & & $(-3.031)$ \\
\hline \multicolumn{13}{|l|}{ Policy variables } \\
\hline Reserve requirement ratio & -2.365 & $-3.909^{\star \star}$ & & & & & & & & & & \\
\hline (Macroprudential policy) & $(-0.526)$ & $(-2.569)$ & & & & & & & & & & \\
\hline Bank rate (EOP) & & & $-13.436^{*}$ & $6.350^{\star \star}$ & & & & & & & & \\
\hline (Monetary policy) & & & $(-1.663)$ & $(2.560)$ & & & & & & & & \\
\hline House-related policy dummy & & & & & 3.445 & $-4.529^{\star \star \star}$ & & & & & & \\
\hline (House-related policy) & & & & & (1.293) & $(-7.118)$ & & & & & & \\
\hline \multirow{2}{*}{$\begin{array}{l}\text { Capital adequacy ratio } \\
\text { (Macroprudential policy) }\end{array}$} & & & & & & & $-0.400^{\star \star \star}$ & $0.099^{\star \star \star}$ & & & & \\
\hline & & & & & & & $(-4.835)$ & $(4.170)$ & & & & \\
\hline \multirow{2}{*}{$\begin{array}{l}\text { Liquidity ratio } \\
\text { (Macroprudential policy) }\end{array}$} & & & & & & & & & -0.287 & 0.132 & & \\
\hline & & & & & & & & & $(-1.224)$ & $(1.602)$ & & \\
\hline \multirow{2}{*}{$\begin{array}{l}\text { Reserves for Impaired Loans/ Gross loans } \\
\text { (Macroprudential policy) }\end{array}$} & & & & & & & & & & & $-4.244^{\star \star \star}$ & 0.582 \\
\hline & & & & & & & & & & & $(-3.469)$ & (1.346) \\
\hline \multicolumn{13}{|l|}{ Constant } \\
\hline Constant & 21.202 & -5.051 & $60.269^{\star \star \star *}$ & $-11.749^{*}$ & $36.604^{\star *}$ & $-6.148^{\star \star \star}$ & $36.869^{* \star *}$ & -0.087 & $36.751^{\star \star *}$ & -2.170 & $34.913^{\star \star \star}$ & -0.278 \\
\hline Number of banks & 113.000 & 166.000 & 113.000 & 166.000 & 113.000 & 166.000 & 98.000 & 142.000 & 113.000 & 153.000 & 108.000 & 152.000 \\
\hline Number of observations & 457 & 1,387 & 457 & 1,387 & 457 & 1,387 & 344 & 498 & 456 & 672 & 413 & 611 \\
\hline R-squared (overall) & 0.001 & 0.054 & 0.001 & 0.052 & 0.000 & 0.064 & 0.010 & 0.098 & 0.006 & 0.125 & 0.047 & 0.110 \\
\hline
\end{tabular}

Source: IMF staff estimates.

Note: The table presents panel fixed-effects regressions on policies and factors affecting credit (Loan) and house price in China between 2000 and 2011. Standard errors are shown under the coefficients. ${ }^{* * *},{ }^{* \star}$, and * denote statistical significance at the 1 percent, 5 percent, and 10 percent levels of confidence based on robust standard errors. For the definition of dependent variables and independent variables, see table 6 , respectively. For sample banks, see annex l. 
Table 14. Results of Individual Variables Based on the Sample of Banks in the East Region

\begin{tabular}{|c|c|c|c|c|c|c|c|c|c|c|c|c|}
\hline & Loans & House Price & Loans & House Price & Loans & House Price & Loans & House Price & Loans & House Price & Loans & House Price \\
\hline \multicolumn{13}{|l|}{ Control variables } \\
\hline \multirow[t]{2}{*}{ Provincial GDP growth } & 0.179 & $0.419^{\star \star}$ & 0.365 & 0.242 & 0.265 & 0.177 & 0.377 & 0.878 & 0.070 & $0.957^{\star \star}$ & 0.496 & $1.041^{* \star}$ \\
\hline & $(0.273)$ & (2.011) & $(0.570)$ & $(1.176)$ & $(0.449)$ & $(0.971)$ & $(0.765)$ & $(1.559)$ & $(0.119)$ & $(2.292)$ & $(0.866)$ & (2.105) \\
\hline \multirow[t]{2}{*}{ Inflation (CPI) } & -0.157 & $3.137^{\star \star \star}$ & 0.057 & $1.705^{\star \star \star}$ & 1.606 & $-1.325^{\star * *}$ & -1.342 & $1.566^{\star * \star}$ & 0.076 & $1.453^{* * *}$ & $-2.287^{* *}$ & $1.297^{\star \star \star}$ \\
\hline & $(-0.081)$ & $(10.170)$ & $(0.042)$ & $(8.531)$ & $(0.937)$ & $(-3.627)$ & $(-1.288)$ & $(2.601)$ & $(0.050)$ & $(3.460)$ & $(-2.163)$ & $(2.808)$ \\
\hline \multirow[t]{2}{*}{ Foreign reserve growth } & -0.108 & 0.086 & 0.014 & -0.083 & -0.316 & $0.342^{\star \star \star}$ & -0.347 & -0.012 & -0.175 & -0.077 & -0.035 & -0.123 \\
\hline & $(-0.527)$ & $(1.118)$ & $(0.066)$ & $(-1.071)$ & $(-1.240)$ & $(3.779)$ & $(-1.459)$ & $(-0.071)$ & $(-0.788)$ & $(-0.592)$ & $(-0.216)$ & $(-0.802)$ \\
\hline \multirow[t]{2}{*}{ NDF (HK) } & -1.454 & $-3.603^{\star \star \star}$ & $-1.452^{* \star}$ & $-1.147^{\star \star \star}$ & $-2.042^{* *}$ & 0.156 & -0.722 & $-0.831^{* *}$ & $-1.166^{*}$ & $-1.070^{\star \star *}$ & -0.235 & $-1.056^{* \star *}$ \\
\hline & $(-0.756)$ & $(-6.311)$ & $(-2.125)$ & $(-6.694)$ & $(-2.426)$ & $(0.730)$ & $(-1.570)$ & $(-2.342)$ & $(-1.799)$ & $(-4.419)$ & $(-0.904)$ & $(-4.119)$ \\
\hline \multirow[t]{2}{*}{ VIX Index } & -0.064 & $-0.441^{\star \star *}$ & -0.307 & $-0.414^{\star \star \star}$ & -0.051 & $-0.564^{\star \star \star}$ & 0.139 & $-0.645^{\star \star \star}$ & -0.114 & $-0.526^{* \star *}$ & -0.166 & $-0.570^{\star \star \star}$ \\
\hline & $(-0.247)$ & $(-5.110)$ & $(-1.263)$ & $(-4.598)$ & $(-0.197)$ & $(-6.662)$ & $(0.682)$ & $(-3.313)$ & $(-0.397)$ & $(-3.621)$ & $(-0.803)$ & $(-3.370)$ \\
\hline \multirow[t]{2}{*}{ Land supply area } & $-0.064^{*}$ & $0.080^{\star \star \star}$ & $-0.069^{*}$ & $0.092^{\star \star *}$ & -0.055 & $0.065^{\star \star \star}$ & 0.011 & $0.121^{\star \star \star}$ & -0.057 & $0.130^{\star \star \star}$ & $-0.068^{*}$ & $0.118^{\star \star \star}$ \\
\hline & $(-1.680)$ & $(6.178)$ & $(-1.811)$ & $(7.656)$ & $(-1.546)$ & $(4.929)$ & $(0.308)$ & (3.331) & $(-1.433)$ & $(5.098)$ & $(-1.725)$ & $(4.280)$ \\
\hline \multirow[t]{2}{*}{ Loan with one lag } & -0.039 & & -0.041 & & -0.038 & & -0.004 & & -0.045 & & -0.109 & \\
\hline & $(-0.553)$ & & $(-0.601)$ & & $(-0.550)$ & & $(-0.078)$ & & $(-0.665)$ & & $(-0.947)$ & \\
\hline \multirow[t]{2}{*}{ Provincial house price with one lag } & & -0.015 & & $-0.050^{\star \star}$ & & $-0.126^{\star \star \star}$ & & $-0.130^{\star \star \star}$ & & $-0.148^{\star \star \star}$ & & $-0.093^{\star \star}$ \\
\hline & & $(-0.521)$ & & $(-1.963)$ & & $(-4.344)$ & & $(-2.609)$ & & $(-3.731)$ & & $(-2.159)$ \\
\hline \multicolumn{13}{|l|}{ Policy variables } \\
\hline Reserve requirement ratio & -0.574 & $-4.136^{\star \star \star}$ & & & & & & & & & & \\
\hline (Macroprudential policy) & $(-0.171)$ & $(-4.026)$ & & & & & & & & & & \\
\hline Bank rate (EOP) & & & -14.192 & $8.404^{\star \star *}$ & & & & & & & & \\
\hline (Monetary policy) & & & $(-1.561)$ & (3.336) & & & & & & & & \\
\hline House-related policy dummy & & & & & 3.762 & $-5.610^{\star \star \star}$ & & & & & & \\
\hline (House-related policy) & & & & & $(1.335)$ & $(-10.017)$ & & & & & & \\
\hline Capital adequacy ratio & & & & & & & $-0.412^{\star * *}$ & $0.098^{* \star *}$ & & & & \\
\hline (Macroprudential policy) & & & & & & & $(-5.305)$ & (3.594) & & & & \\
\hline Liquidity ratio & & & & & & & & & -0.236 & 0.122 & & \\
\hline (Macroprudential policy) & & & & & & & & & $(-0.898)$ & $(1.292)$ & & \\
\hline Reserves for Impaired Loans/ Gross loans & & & & & & & & & & & $-5.010^{* \star \star}$ & -0.552 \\
\hline (Macroprudential policy) & & & & & & & & & & & $(-3.677)$ & $(-1.047)$ \\
\hline \multicolumn{13}{|l|}{ Constant } \\
\hline Constant & $27.575^{*}$ & $-7.696^{\star \star \star}$ & $63.793^{\star \star \star}$ & $-19.348^{\star \star \star}$ & $39.266^{\star \star}$ & $-11.664^{\star \star \star}$ & $39.193^{\star \star \star}$ & -3.246 & $37.057^{\star \star}$ & -4.768 & $39.696^{\star \star \star}$ & -0.746 \\
\hline Number of banks & 96.000 & 130.000 & 96.000 & 130.000 & 96.000 & 130.000 & 83.000 & 109.000 & 96.000 & 120.000 & 92.000 & 119.000 \\
\hline Number of observations & 408 & 1,121 & 408 & 1,121 & 408 & 1,121 & 307 & 411 & 407 & 562 & 366 & 505 \\
\hline R-squared (overall) & 0.001 & 0.169 & 0.001 & 0.167 & 0.003 & 0.223 & 0.012 & 0.126 & 0.001 & 0.165 & 0.072 & 0.153 \\
\hline
\end{tabular}

Source: IMF staff estimates.

Note: The table presents panel fixed-effects regressions on policies and factors affecting credit (Loan) and house price in China between 2000 and 2011. Standard errors are shown under the coefficients. ${ }^{* * *},{ }^{* *}$, and ${ }^{*}$ denote statistical significance at the 1 percent, 5 percent, and 10 percent levels of confidence based on robust standard errors. For the definition of dependent variables and independent variables, see table 6 , respectively. For sample banks, see annex I. 
Table 15. Results of Individual Variables Based on the Sample of Banks in the Middle Region

\begin{tabular}{|c|c|c|c|c|c|c|c|c|c|c|c|c|}
\hline & Loans & House Price & Loans & House Price & Loans & House Price & Loans & House Price & Loans & House Price & Loans & House Price \\
\hline \multicolumn{13}{|l|}{ Control variables } \\
\hline \multirow[t]{2}{*}{ Provincial GDP growth } & 0.809 & 1.294 & 0.852 & 1.346 & 1.232 & 1.314 & 0.463 & 0.013 & 0.674 & 0.311 & 0.491 & 0.118 \\
\hline & $(0.684)$ & (1.325) & $(0.668)$ & (1.249) & $(0.880)$ & $(1.030)$ & $(0.174)$ & $(0.018)$ & $(0.556)$ & $(0.547)$ & $(0.428)$ & $(0.184)$ \\
\hline \multirow[t]{2}{*}{ Inflation (CPI) } & 1.253 & 1.838 & -1.115 & 3.235 & 0.726 & 3.095 & -1.687 & 1.664 & -1.158 & 0.793 & -0.102 & 0.126 \\
\hline & $(0.192)$ & $(1.198)$ & $(-0.696)$ & $(0.925)$ & $(0.556)$ & $(0.709)$ & $(-0.373)$ & (1.241) & $(-0.686)$ & $(0.535)$ & $(-0.050)$ & $(0.074)$ \\
\hline \multirow[t]{2}{*}{ Foreign reserve growth } & 0.071 & -1.232 & -0.003 & -1.146 & $-0.322^{* \star *}$ & -1.116 & 0.076 & 0.009 & 0.058 & -0.126 & -0.363 & 0.164 \\
\hline & $(0.244)$ & $(-0.878)$ & $(-0.014)$ & $(-0.948)$ & $(-3.092)$ & $(-0.869)$ & $(0.187)$ & $(0.042)$ & $(0.393)$ & $(-0.887)$ & $(-1.617)$ & $(0.753)$ \\
\hline \multirow[t]{2}{*}{ NDF (HK) } & -4.566 & 2.762 & $-1.730^{\star \star \star}$ & 0.348 & $-2.946^{\star \star \star}$ & 0.443 & $-1.478^{\star \star \star}$ & -0.512 & $-1.680^{\star \star \star}$ & -0.671 & $-1.547^{\star \star \star}$ & -0.705 \\
\hline & $(-0.555)$ & $(0.372)$ & $(-2.633)$ & $(0.321)$ & $(-6.592)$ & $(0.645)$ & $(-3.428)$ & $(-0.940)$ & $(-3.616)$ & $(-1.372)$ & $(-3.457)$ & $(-1.445)$ \\
\hline \multirow[t]{2}{*}{ VIXIndex } & 0.603 & -1.660 & 0.597 & -1.590 & $0.755^{\star \star}$ & -1.609 & 0.469 & $-0.706^{*}$ & 0.640 & $-0.602^{\star \star \star}$ & 0.501 & $-0.586^{\star \star}$ \\
\hline & $(1.211)$ & $(-1.005)$ & $(0.926)$ & $(-1.103)$ & $(2.523)$ & $(-1.114)$ & $(0.790)$ & $(-1.937)$ & $(1.387)$ & $(-2.594)$ & $(1.190)$ & $(-2.378)$ \\
\hline \multirow[t]{2}{*}{ Land supply area } & -0.009 & 0.110 & -0.005 & 0.105 & -0.008 & 0.104 & -0.017 & 0.001 & -0.006 & -0.005 & -0.004 & -0.009 \\
\hline & $(-0.552)$ & $(0.893)$ & $(-0.279)$ & $(0.948)$ & $(-0.286)$ & $(0.925)$ & $(-0.424)$ & $(0.105)$ & $(-0.306)$ & $(-0.350)$ & $(-0.189)$ & $(-0.530)$ \\
\hline \multirow[t]{2}{*}{ Loan with one lag } & $-0.606^{\star \star \star}$ & & $-0.601^{\star \star \star}$ & & $-0.625^{\star \star \star}$ & & $-0.338^{\star \star}$ & & $-0.616^{\star \star \star}$ & & $-0.645^{\star \star \star}$ & \\
\hline & $(-4.574)$ & & $(-4.351)$ & & $(-4.936)$ & & $(-2.081)$ & & $(-4.674)$ & & $(-4.629)$ & \\
\hline \multirow[t]{2}{*}{ Provincial house price with one lag } & & -0.042 & & -0.032 & & -0.039 & & $-0.225^{\star \star}$ & & $-0.314^{\star \star \star}$ & & $-0.288^{\star \star}$ \\
\hline & & $(-0.164)$ & & $(-0.119)$ & & $(-0.124)$ & & $(-2.511)$ & & $(-2.704)$ & & $(-2.403)$ \\
\hline \multicolumn{13}{|l|}{ Policy variables } \\
\hline Reserve requirement ratio & -5.061 & 4.363 & & & & & & & & & & \\
\hline (Macroprudential policy) & $(-0.350)$ & $(0.373)$ & & & & & & & & & & \\
\hline Bank rate (EOP) & & & -2.444 & 0.556 & & & & & & & & \\
\hline (Monetary policy) & & & $(-0.144)$ & $(0.077)$ & & & & & & & & \\
\hline House-related policy dummy & & & & & $5.453^{\star \star}$ & -0.414 & & & & & & \\
\hline (House-related policy) & & & & & $(2.560)$ & $(-0.151)$ & & & & & & \\
\hline Capital adequacy ratio & & & & & & & 0.590 & 0.948 & & & & \\
\hline (Macroprudential policy) & & & & & & & $(0.477)$ & (1.227) & & & & \\
\hline Liquidity ratio & & & & & & & & & 0.173 & $-0.431^{\star *}$ & & \\
\hline (Macroprudential policy) & & & & & & & & & $(0.544)$ & $(-2.377)$ & & \\
\hline Reserves for Impaired Loans/ Gross loans & & & & & & & & & & & $-5.794^{*}$ & 4.631 \\
\hline (Macroprudential policy) & & & & & & & & & & & $(-1.792)$ & $(1.274)$ \\
\hline \multicolumn{13}{|l|}{ Constant } \\
\hline Constant & 17.215 & 30.248 & 35.236 & 19.346 & $44.092^{\star \star}$ & 19.989 & 18.813 & -0.781 & 25.985 & $21.961^{\star \star}$ & $56.961^{\star \star}$ & -2.149 \\
\hline Number of banks & 12.000 & 24.000 & 12.000 & 24.000 & 12.000 & 24.000 & 11.000 & 22.000 & 12.000 & 22.000 & 11.000 & 22.000 \\
\hline Number of observations & 35 & 180 & 35 & 180 & 35 & 180 & 29 & 61 & 35 & 78 & 34 & 75 \\
\hline R-squared (overall) & 0.007 & 0.045 & 0.006 & 0.045 & 0.003 & 0.045 & 0.033 & 0.218 & 0.007 & 0.128 & 0.115 & 0.061 \\
\hline
\end{tabular}

R-squared (overall)

Source: IMF staff estimates.

Note: The table presents panel fixed-effects regressions on policies and factors affecting credit (Loan) and house price in China between 2000 and 2011. Standard errors are shown under the coefficients. ${ }^{* * *},{ }^{* *}$, and * denote statistical significance at the 1 percent, 5 percent, and 10 percent levels of confidence based on robust standard errors. For the definition of dependent variables and independent variables, see table 6 , respectively. For sample banks, see annex I. 
Table 16. Results of Individual Variables Based on the Sample of Banks in the West Region

\begin{tabular}{|c|c|c|c|c|c|c|c|c|c|c|c|c|}
\hline & Loans & House Price & Loans & House Price & Loans & House Price & Loans & House Price & Loans & House Price & Loans & House Price \\
\hline \multicolumn{13}{|l|}{ Control variables } \\
\hline \multirow[t]{2}{*}{ Provincial GDP growth } & 1.100 & 0.572 & 0.702 & 0.471 & 0.495 & 0.380 & 0.954 & 0.743 & 0.518 & 0.686 & 0.793 & $0.854^{\star \star}$ \\
\hline & $(1.374)$ & $(1.632)$ & $(0.877)$ & $(1.460)$ & $(0.718)$ & $(1.350)$ & $(1.143)$ & $(1.598)$ & $(0.822)$ & $(1.574)$ & $(1.118)$ & $(2.027)$ \\
\hline \multirow[t]{2}{*}{ Inflation (CPI) } & 3.985 & -0.072 & -0.904 & -0.616 & -2.565 & -1.150 & -2.334 & -1.201 & -0.994 & -1.748 & -2.191 & -1.445 \\
\hline & $(0.944)$ & $(-0.099)$ & $(-0.291)$ & $(-0.781)$ & $(-0.744)$ & $(-0.942)$ & $(-1.335)$ & $(-0.625)$ & $(-0.369)$ & $(-1.594)$ & $(-1.347)$ & $(-1.059)$ \\
\hline \multirow[t]{2}{*}{ Foreign reserve growth } & 0.138 & -0.010 & 0.151 & -0.124 & -0.051 & 0.016 & -0.116 & 0.397 & -0.259 & 0.179 & -0.049 & 0.198 \\
\hline & $(0.632)$ & $(-0.075)$ & $(0.524)$ & $(-0.926)$ & $(-0.091)$ & $(0.122)$ & $(-0.363)$ & $(1.020)$ & $(-0.687)$ & $(1.325)$ & $(-0.192)$ & $(1.117)$ \\
\hline \multirow[t]{2}{*}{$\overline{N D F}(H K)$} & $-10.115^{*}$ & -1.301 & -1.048 & -0.240 & 0.236 & 0.055 & 0.164 & 0.217 & -0.195 & -0.223 & -0.461 & -0.024 \\
\hline & $(-1.705)$ & $(-1.431)$ & $(-1.450)$ & $(-0.553)$ & $(0.191)$ & $(0.116)$ & $(0.398)$ & $(0.325)$ & $(-0.473)$ & $(-0.360)$ & $(-1.240)$ & $(-0.042)$ \\
\hline \multirow[t]{2}{*}{ VIX Index } & 0.138 & 0.096 & -0.503 & 0.140 & 0.038 & 0.030 & 0.072 & -0.083 & -0.060 & 0.239 & -0.157 & -0.063 \\
\hline & $(0.372)$ & $(0.613)$ & $(-0.978)$ & $(0.861)$ & $(0.130)$ & $(0.192)$ & $(0.217)$ & $(-0.378)$ & $(-0.146)$ & $(0.942)$ & $(-0.654)$ & $(-0.226)$ \\
\hline \multirow[t]{2}{*}{ Land supply area } & -0.021 & $0.023^{\star \star}$ & 0.008 & $0.026^{\star \star}$ & $0.028^{\star \star \star}$ & $0.023^{* \star}$ & $0.051^{\star \star}$ & $0.027^{* *}$ & $0.029^{\star \star \star}$ & 0.022 & $0.023^{*}$ & $0.027^{\star \star}$ \\
\hline & $(-0.542)$ & $(2.108)$ & $(0.770)$ & $(2.505)$ & $(2.768)$ & $(1.975)$ & $(2.244)$ & $(2.210)$ & $(3.341)$ & $(1.607)$ & $(1.806)$ & $(2.088)$ \\
\hline \multirow[t]{2}{*}{ Loan with one lag } & -0.183 & & -0.083 & & $-0.207^{\star \star}$ & & $-0.302^{* \star *}$ & & $-0.225^{*}$ & & $-0.256^{* \star \star}$ & \\
\hline & $(-1.091)$ & & $(-0.644)$ & & $(-2.310)$ & & $(-2.820)$ & & $(-1.650)$ & & $(-3.982)$ & \\
\hline \multirow[t]{2}{*}{ Provincial house price with one lag } & & $-0.122^{*}$ & & $-0.143^{* *}$ & & $-0.172^{* *}$ & & -0.176 & & -0.170 & & $-0.215^{* \star}$ \\
\hline & & $(-1.857)$ & & $(-2.143)$ & & $(-2.215)$ & & $(-1.556)$ & & $(-1.494)$ & & $(-1.978)$ \\
\hline \multicolumn{13}{|l|}{ Policy variables } \\
\hline Reserve requirement ratio & $-17.239^{*}$ & -1.671 & & & & & & & & & & \\
\hline (Macroprudential policy) & $(-1.739)$ & $(-0.952)$ & & & & & & & & & & \\
\hline $\begin{array}{l}\text { Bank rate }(E O P) \\
\end{array}$ & & & $-30.678^{\star \star}$ & 5.338 & & & & & & & & \\
\hline (Monetary policy) & & & $(-2.231)$ & $(1.060)$ & & & & & & & & \\
\hline House-related policy dummy & & & & & -2.081 & -1.679 & & & & & & \\
\hline (House-related policy) & & & & & $(-0.538)$ & $(-1.090)$ & & & & & & \\
\hline Capital adequacy ratio & & & & & & & -0.468 & 0.655 & & & & \\
\hline (Macroprudential policy) & & & & & & & $(-0.715)$ & $(0.686)$ & & & & \\
\hline Liquidity ratio & & & & & & & & & -0.214 & $0.384^{\star \star}$ & & \\
\hline (Macroprudential policy) & & & & & & & & & $(-0.538)$ & $(2.045)$ & & \\
\hline Reserves for Impaired Loans/ Gross loans & & & & & & & & & & & $5.026^{\star \star \star}$ & 2.075 \\
\hline (Macroprudential policy) & & & & & & & & & & & (6.423) & $(1.211)$ \\
\hline \multicolumn{13}{|l|}{ Constant } \\
\hline Constant & -10.329 & 1.214 & $108.175^{\star \star}$ & $\begin{array}{ll}-7.467 \\
\end{array}$ & 25.418 & 3.172 & $33.765^{*}$ & -13.424 & $38.725^{*}$ & -8.874 & 13.427 & -7.992 \\
\hline Number of banks & 10.000 & 17.000 & 10.000 & 17.000 & 10.000 & 17.000 & 9.000 & 16.000 & 10.000 & 16.000 & 10.000 & 16.000 \\
\hline Number of observations & 42 & 136 & 42 & 136 & 42 & 136 & 36 & 62 & 42 & 70 & 41 & 69 \\
\hline R-squared (overall) & 0.060 & 0.071 & 0.076 & 0.072 & 0.000 & 0.078 & 0.000 & 0.180 & 0.001 & 0.169 & 0.000 & 0.091 \\
\hline
\end{tabular}

Source: IMF staff estimates

Note: The table presents panel fixed-effects regressions on policies and factors affecting credit (Loan) and house price in China between 2000 and 2011. Standard errors are shown under the

coefficients. ${ }^{* * *},{ }^{* *}$, and * denote statistical significance at the 1 percent, 5 percent, and 10 percent levels of confidence based on robust standard errors. For the definition of dependent variables and independent variables, see table 6 , respectively. For sample banks, see annex I. 
Table 17. Results of Multivariate Policies: Grouped by Size of Banks and Regions

\begin{tabular}{|c|c|c|c|c|c|c|c|c|c|c|c|c|}
\hline & \multicolumn{6}{|c|}{ Grouped by Size of Banks } & \multicolumn{6}{|c|}{ Grouped by Regions } \\
\hline & \multicolumn{2}{|c|}{ Full Sample } & \multicolumn{2}{|c|}{ Large Banks } & \multicolumn{2}{|c|}{ Small/Medium Banks } & \multicolumn{2}{|r|}{ East } & \multicolumn{2}{|c|}{ West } & \multicolumn{2}{|c|}{ Middle } \\
\hline & Loans & House Price & Loans & House Price & Loans & fouse Price & Loans & House Price & Loans & House Price & Loans & House Price \\
\hline \multicolumn{13}{|l|}{ Control variables } \\
\hline \multirow[t]{2}{*}{ Provincial GDP growth } & 0.312 & 0.481 & 0.929 & $-1.183^{\star \star *}$ & 0.410 & $0.556^{*}$ & 0.347 & $0.372^{* *}$ & 0.895 & 0.477 & 0.918 & 1.245 \\
\hline & $(0.542)$ & (1.621) & $(0.826)$ & $(-3.374)$ & $(0.650)$ & $(1.933)$ & $(0.522)$ & $(1.978)$ & $(1.180)$ & (1.630) & $(0.635)$ & $(1.092)$ \\
\hline \multirow{2}{*}{ Inflation (CPI) } & 1.057 & 0.609 & -0.871 & -0.493 & 1.185 & 0.793 & 0.840 & 0.253 & 0.825 & -0.352 & 8.638 & 1.346 \\
\hline & $(0.745)$ & $(0.979)$ & $(-0.466)$ & $(-0.142)$ & $(0.739)$ & $(1.310)$ & $(0.598)$ & $(0.479)$ & $(0.114)$ & $(-0.262)$ & $(1.131)$ & $(0.804)$ \\
\hline \multirow[t]{2}{*}{ Foreign reserve growth } & -0.134 & 0.089 & -0.169 & $0.477^{\star}$ & -0.111 & 0.081 & -0.168 & $0.298^{\star \star \star}$ & 0.421 & -0.005 & -0.387 & -1.158 \\
\hline & $(-0.512)$ & $(0.401)$ & $(-0.900)$ & $(1.939)$ & $(-0.389)$ & $(0.346)$ & $(-0.586)$ & (3.498) & $(0.868)$ & $(-0.029)$ & $(-0.694)$ & $(-0.786)$ \\
\hline \multirow[t]{2}{*}{ NDF (HK) } & -1.607 & $-1.963^{* \star *}$ & $-0.881^{* * *}$ & -1.150 & -1.910 & $-2.295^{\star \star \star}$ & -1.324 & $-2.492^{\star \star \star}$ & -5.892 & -1.670 & -12.494 & 3.420 \\
\hline & $(-1.013)$ & $(-2.882)$ & $(-3.301)$ & $(-0.424)$ & $(-0.756)$ & $(-2.715)$ & $(-0.847)$ & $(-4.000)$ & $(-0.817)$ & $(-1.525)$ & $(-1.280)$ & $(0.455)$ \\
\hline \multirow[t]{2}{*}{ VIX Index } & -0.212 & $-0.462^{\star \star \star *}$ & -0.458 & $-0.222^{*}$ & -0.184 & $-0.456^{* \star}$ & -0.247 & $-0.338^{\star \star \star}$ & -0.296 & 0.207 & $1.270^{\star \star}$ & -1.765 \\
\hline & $(-1.150)$ & $(-2.702)$ & $(-1.176)$ & $(-1.761)$ & $(-0.948)$ & $(-2.406)$ & $(-1.157)$ & $(-3.852)$ & $(-0.814)$ & $(1.054)$ & $(2.563)$ & $(-1.021)$ \\
\hline \multirow[t]{2}{*}{ Land supply area } & -0.036 & $0.067^{* *}$ & 0.038 & 0.018 & -0.036 & $0.067^{\star}$ & $-0.061^{*}$ & $0.068^{\star \star \star}$ & -0.013 & 0.018 & -0.015 & 0.110 \\
\hline & $(-1.460)$ & $(1.981)$ & $(1.221)$ & $(0.671)$ & $(-1.313)$ & $(1.907)$ & $(-1.737)$ & $(5.757)$ & $(-0.439)$ & $(1.580)$ & $(-0.547)$ & $(0.866)$ \\
\hline \multirow[t]{2}{*}{ Loan with one lag } & -0.055 & & -0.058 & & -0.057 & & -0.041 & & -0.115 & & $-0.650^{\star \star \star}$ & \\
\hline & $(-0.794)$ & & $(-0.371)$ & & $(-0.809)$ & & $(-0.588)$ & & $(-0.746)$ & & $(-5.196)$ & \\
\hline \multirow[t]{2}{*}{ Provincial house price with one lag } & & $-0.118^{\star \star \star}$ & & -0.003 & & $-0.124^{\star \star \star}$ & & $-0.122^{\star \star \star}$ & & $-0.153^{\star}$ & & -0.048 \\
\hline & & $(-3.775)$ & & $(-0.123)$ & & $(-3.846)$ & & $(-4.264)$ & & $(-1.759)$ & & $(-0.168)$ \\
\hline \multicolumn{13}{|l|}{ Policy variables } \\
\hline \multirow{2}{*}{$\begin{array}{l}\text { Reserve requirement ratio } \\
\text { (Macroprudential policy) }\end{array}$} & 0.526 & $-4.160^{\star \star \star}$ & & 0.020 & 0.052 & $-4.717^{* \star *}$ & 1.285 & $-5.045^{* \star *}$ & -10.114 & -3.219 & -17.584 & 5.421 \\
\hline & $(0.148)$ & $(-4.078)$ & & $(0.003)$ & $(0.010)$ & $(-3.556)$ & $(0.356)$ & $(-5.538)$ & $(-0.985)$ & $(-1.604)$ & $(-0.929)$ & $(0.424)$ \\
\hline \multirow{2}{*}{$\begin{array}{l}\text { Bank rate (EOP) } \\
\text { (Monetary policy) }\end{array}$} & -11.019 & $6.707^{\star \star \star}$ & -43.770 & $17.340^{*}$ & -9.476 & $6.578^{\star \star \star}$ & -10.827 & $7.809^{\star \star \star}$ & $-21.813^{* *}$ & 7.075 & $33.683^{* *}$ & -4.753 \\
\hline & $(-1.367)$ & $(3.344)$ & $(-1.611)$ & $(1.958)$ & $(-1.052)$ & $(3.513)$ & $(-1.185)$ & $(4.328)$ & $(-2.574)$ & $(1.020)$ & $(2.083)$ & $(-0.525)$ \\
\hline \multirow{2}{*}{$\begin{array}{l}\text { House-related policy dummy } \\
\text { (House-related policy) }\end{array}$} & 2.312 & $-4.328^{* \star *}$ & -0.531 & $-4.596^{\star \star *}$ & 2.448 & $-4.133^{\star \star *}$ & 2.661 & $-5.182^{\star \star *}$ & -2.801 & -1.256 & 6.876 & -0.727 \\
\hline & $(0.907)$ & $(-7.021)$ & $(-0.299)$ & $(-5.994)$ & $(0.963)$ & $(-6.547)$ & $(0.958)$ & $(-9.851)$ & $(-0.595)$ & $(-0.675)$ & $(1.336)$ & $(-0.282)$ \\
\hline \multicolumn{13}{|l|}{ Constant } \\
\hline \multirow[t]{2}{*}{$\begin{array}{l}\text { Constant } \\
\text {. }\end{array}$} & $63.929^{* \star}$ & $-32.221^{\star \star \star}$ & $145.407^{\star *}$ & $-50.469^{\star \star}$ & 57.427 & $-32.986^{\star \star \star}$ & $65.747^{\star *}$ & $-42.244^{\star \star \star}$ & $52.765^{*}$ & -21.840 & -76.952 & 43.154 \\
\hline & $(2.343)$ & $(-6.141)$ & (2.193) & $(-2.039)$ & $(1.611)$ & $(-6.202)$ & $(2.305)$ & $(-8.128)$ & $(1.900)$ & $(-1.231)$ & $(-1.091)$ & $(0.791)$ \\
\hline Number of banks & 118.000 & 171.000 & 5.000 & 5.000 & 113.000 & 166.000 & 96.000 & 130.000 & 10.000 & 17.000 & 12.000 & 24.000 \\
\hline Number of observations & 485 & 1,437 & 28 & & 457 & 1,387 & 408 & 1,121 & 42 & 136 & 35 & 180 \\
\hline R-squared (overall) & 0.000 & 0.069 & 0.617 & 0.596 & 0.000 & 0.067 & 0.002 & 0.232 & 0.110 & 0.098 & 0.007 & 0.045 \\
\hline
\end{tabular}

Source: IMF staff estimates.

Note: The table presents panel fixed-effects regressions on policies and factors affecting credit (Loan) and house price in China between 2000 and 2011. The results are presented for the whole sample and two groups of banks with different size as well as for three separate regions. Dependent variables are annually loan growth in each bank and house price in each province. House-related policy dummy exclude the monetary polcies. VIX index and Resever requirement ratio are in first-differences (d_). T-statistics are in parenthesis. ${ }^{* * *}$, ${ }^{* *}$, and ${ }^{*}$ denote statistical significance at the 1 percent, 5 percent, and 10 percent level of confidence based on robust standard errors. 
Table 18. Results of Multivariate Policies: Subgroups in Small- and Medium-Sized Banks

\begin{tabular}{|c|c|c|c|c|c|c|}
\hline & \multicolumn{2}{|c|}{ Foreign Banks } & \multicolumn{2}{|c|}{ City Commercial Banks } & \multicolumn{2}{|c|}{ Joint-stock Commercial Banks } \\
\hline & Loans & House Price & Loans & House Price & Loans & House Price \\
\hline \multicolumn{7}{|l|}{ Control variables } \\
\hline \multirow[t]{2}{*}{ Provincial GDP growth } & 4.135 & 0.231 & 0.076 & $0.554^{\star}$ & 0.806 & -0.238 \\
\hline & $(1.125)$ & $(1.468)$ & $(0.126)$ & $(1.847)$ & $(0.850)$ & $(-0.658)$ \\
\hline \multirow{2}{*}{ Inflation (CPI) } & $-8.589^{\star *}$ & $2.889^{\star \star \star}$ & 1.502 & 0.087 & $5.421^{*}$ & -1.644 \\
\hline & $(-2.460)$ & (3.021) & $(0.840)$ & $(0.108)$ & $(1.651)$ & $(-1.153)$ \\
\hline \multirow{2}{*}{ Foreign reserve growth } & -0.595 & $0.423^{\star \star \star}$ & 0.062 & -0.012 & -0.430 & $0.255^{* \star}$ \\
\hline & $(-0.598)$ & $(6.358)$ & $(0.169)$ & $(-0.040)$ & $(-0.693)$ & $(2.278)$ \\
\hline \multirow{2}{*}{ NDF (HK) } & $21.705^{\star \star \star}$ & $-7.604^{* * *}$ & $-5.155^{\star}$ & -0.369 & $-8.358^{\star \star}$ & -0.466 \\
\hline & (3.187) & $(-6.644)$ & $(-1.733)$ & $(-0.306)$ & $(-2.154)$ & $(-0.214)$ \\
\hline \multirow{2}{*}{ VIX Index } & $-1.291^{* *}$ & $-0.210^{\star *}$ & 0.005 & $-0.611^{* *}$ & 0.582 & -0.088 \\
\hline & $(-2.349)$ & $(-1.997)$ & $(0.021)$ & $(-2.109)$ & $(0.665)$ & $(-1.509)$ \\
\hline \multirow{2}{*}{ Land supply area } & 0.171 & $0.081^{* * *}$ & -0.038 & 0.070 & -0.050 & 0.011 \\
\hline & (1.374) & $(5.307)$ & $(-1.416)$ & $(1.569)$ & $(-0.527)$ & $(0.392)$ \\
\hline \multirow{2}{*}{ Loan with one lag } & -0.101 & & -0.087 & & -0.029 & \\
\hline & $(-1.186)$ & & $(-0.617)$ & & $(-0.154)$ & \\
\hline \multirow{2}{*}{ Provincial house price with one lag } & & -0.034 & & $-0.143^{* \star *}$ & & -0.125 \\
\hline & & $(-0.866)$ & & $(-2.883)$ & & $(-1.314)$ \\
\hline \multicolumn{7}{|l|}{ Policy variables } \\
\hline \multirow{2}{*}{$\begin{array}{l}\text { Reserve requi rement ratio } \\
\text { (Macroprudential policy) }\end{array}$} & $54.972^{* * *}$ & $-11.759^{\star \star \star}$ & -8.627 & -1.919 & -10.987 & -0.185 \\
\hline & $(3.014)$ & $(-6.797)$ & $(-1.433)$ & $(-0.960)$ & $(-1.360)$ & $(-0.051)$ \\
\hline \multirow{2}{*}{$\begin{array}{l}\text { Bank rate (EOP) } \\
\text { (Monetarypolicy) }\end{array}$} & $-110.685^{* *}$ & 5.602 & 8.443 & $4.334^{*}$ & -14.142 & $17.532^{* * *}$ \\
\hline & $(-2.147)$ & $(1.570)$ & $(0.885)$ & $(1.956)$ & $(-1.235)$ & $(6.157)$ \\
\hline \multirow{2}{*}{$\begin{array}{l}\text { House-related policy dummy } \\
\text { (House-related policy) }\end{array}$} & $13.099^{*}$ & $-2.854^{* * *}$ & -1.793 & $-4.286^{\star \star \star}$ & $8.000^{*}$ & $-6.415^{* * *}$ \\
\hline & $(1.691)$ & $(-3.539)$ & $(-0.715)$ & $(-4.988)$ & $(1.744)$ & $(-4.260)$ \\
\hline \multicolumn{7}{|l|}{ Constant } \\
\hline \multirow[t]{2}{*}{ Constant } & $419.805^{\star \star \star}$ & $-43.155^{\star \star \star}$ & -14.028 & $-20.047^{\star \star}$ & 74.735 & $-59.272^{\star \star \star}$ \\
\hline & $(2.681)$ & $(-4.754)$ & $(-0.356)$ & $(-2.396)$ & $(1.468)$ & $(-7.822)$ \\
\hline Number of banks & 22.000 & 29.000 & 79.000 & 123.000 & 8.000 & 10.000 \\
\hline Number of observations & 76 & 284 & 319 & 966 & 47 & 100 \\
\hline R-squared (overall) & 0.142 & 0.409 & 0.001 & 0.050 & 0.343 & 0.641 \\
\hline
\end{tabular}

Source: IMF staff estimates.

Note: The table presents panel fixed-effects regressions on policies and factors affecting credit (Loan) and house price in China between 2000 and 2011. The results are presented for the three subgroups of banks in small-and medium-sized banks. Dependent variables are annually loan growth in each bank and house price in each province. House-related policy dummy exclude the monetary policies. VIX index and Res erve requirement ratio are in first-differences (d_). T-statistics are in parenthesis. ***, **, and * denote statistical significance at the 1 percent, 5 percent, and 10 percent level of confidence based on robust standard errors. 